JULIANA ROSSI PEREIRA ROCHA

\title{
A GESTÃO DO DESENVOLVIMENTO DE PRODUTO VIA APQP NA INDÚSTRIA AUTOMOBILÍSTICA
}

Dissertação apresentada à Escola Politécnica da Universidade de São Paulo para obtenção do título de mestre em Engenharia de Produção

Área de concentração: Engenharia de Produção

Orientador:

Prof. Dr. Mario Sergio Salerno 
JULIANA ROSSI PEREIRA ROCHA

\section{A GESTÃO DO DESENVOLVIMENTO DE PRODUTO VIA APQP NA INDÚSTRIA AUTOMOBILÍSTICA}

Dissertação apresentada à Escola

Politécnica da Universidade de São

Paulo para obtenção do título de mestre em Engenharia de Produção 



\section{DEDICATÓRIA}

Aos meus avós, Ernesto e Tereza, que

foram um exemplo de caráter e bondade

(in memorian) 


\section{AGRADECIMENTOS}

A Deus, que me deu tantas oportunidades e me guia todos os dias para que eu saiba como aproveitá-las.

Ao Prof. Dr. Mario Salerno, pelo apoio, compreensão e orientação competente e segura. Minha admiração e meu muito obrigada professor!

À Danielle, sempre me guiando para o melhor de mim mesma, sem a qual eu certamente não estaria onde estou.

A todos os meus amigos que me apoiaram, sem os quais eu não teria conseguido finalizar este trabalho, em especial às minhas amigas Adriana, Adriana Valério, Stefânia e Graziela.

Ao Luciano, por sempre me incentivar a acreditar que eu posso ir mais longe.

A todas as pessoas que contribuíram para a realização das entrevistas, em especial Ligia, Camila e Elen.

À minha mãe e irmã, que me apoiaram em todo o processo. Ao meu cunhado Tasso, por estar sempre por perto para ajudar.

A todos os professores e colaboradores do Depto. De Eng. de Escola Politécnica, que de alguma maneira contribuíram com seu conhecimento. 


\section{RESUMO}

O processo de desenvolvimento de produto (PDP) é reconhecido por influenciar diretamente a competitividade das empresas. $O$ sucesso do desenvolvimento pode contribuir, entre outros resultados, no aumento da participação de mercado, conquista de novos clientes, redução de custos e melhora da qualidade. O PDP realizado entre montadora de veículos e fornecedor requer atenção especial no que diz respeito à gestão do processo e à interação entre as empresas. Isso porque, em muitos casos, fornecedores detêm o conhecimento tecnológico do produto e processo de produção do mesmo e a montadora detém o conhecimento das necessidades de performance do projeto. Dentro destas duas instituições, montadora e fornecedor, ocorre um movimento que envolve competências, responsabilidades e a atuação de diversas áreas funcionais. Todo este processo requer integração, comunicação e estrutura, para que possa ocorrer de maneira organizada. Montadoras americanas desenvolveram uma metodologia que busca suprir algumas das necessidades de integração no PDP, o Planejamento Avançado da Qualidade do Produto (APQP). O objetivo deste trabalho é discutir esta metodologia, identificando condições em que o APQP contribui para a gestão do processo de desenvolvimento do produto. Este trabalho foi desenvolvido por meio de estudos de casos da indústria automotiva, entre os quais dois estudos com maior profundidade. Em um segundo momento, foi pesquisado um grupo maior, de 20 fornecedores de um mesmo projeto, para avaliar se as conclusões obtidas nos dois casos mais aprofundados eram representativas para um grupo amplo. Nos casos estudados, foi possível identificar que atrasos por parte da montadora dificultam a gestão do processo. O fornecedor, ao trabalhar próximo do cliente, obtém informações que possibilitam administrar atrasos e prazos comprimidos, muitas vezes antecipando-se a formalizações da montadora. Isso tem custos adicionais, mas revela que o APQP pode contribuir positivamente na interação, fornecendo subsídios para um alinhamento constante. Porém, não impede que falhas internas na montadora sejam evitadas.

Palavras chave: APQP, desenvolvimento de produto, indústria automobilística 


\section{RESUME}

The product development process (PDP) is recognized for having direct influence on company's competitiveness. The success of PDP can influence other objectives, some of them: market share increasing, new customers, cost reduction and quality improvement. The OEMs (Original Equipments Manufactures) and automotive parts manufacturers PDP require special attention on the process management and interaction between the companies. These because, in many cases, suppliers hold the technical knowledge of the product and production process and the OEMs hold the requirements and project performance knowledge. Inside those companies, OEMs and auto parts suppliers there is a process which involves competencies, responsibilities and work from several functional areas. The success of those projects requires integration, communication and a well organized structure to make it happen on an organized way. Auto makers have developed a methodology to supply some integration requirements between the players on the PDP and the Advanced Product Quality Planning (APQP). The objective of this paper is to discuss the methodology, indentifying conditions which will contribute for new product development management. This paper was developed on case studies from automotive industry. First, two deep studies cases was made. In a second moment, a more extensive study was done with 20 suppliers of the same project, to evaluate if the conclusion on the primary study were representatives into a large group. On the two moments, it was possible to indentify that delays on car manufacturer make more difficult to manage the process. However, the supplier can work closely to client and make possible to have an easier communication process. This communication enables to track the delays and deadlines, and sometimes work in advanced. This have additional costs, but shows that the APQP can contribute on the interaction, giving assistance for supplies have a constant alignment, on the other hand cannot guarantee to avoid errors and internal failures on the car makers.

Key words: APQP, product development, Automotive Industry 


\section{LISTA DE FIGURAS}

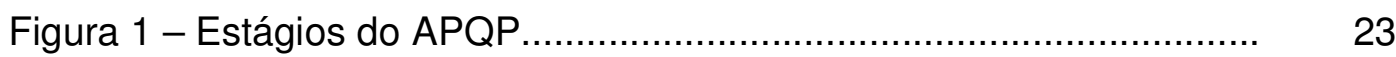

Figura 2 - Dimensões das soluções de problemas................................ 32

Figura 3 - Stage-gate®: cinco estágios e cinco pontos de decisão da descoberta à fase de pós-lançamento.................................................. 40

Figura 4 - Integração entre lead time, qualidade e produtividade................ 49

Figura 5 - Formas de organização do processo de desenvolvimento de produto.............................................................................. 50

Figura 6: Processos relacionados com o desenvolvimento de produto....... 54

Figura 7 - Ciclo de desenvolvimento de produto .................................. 55

Figura 8: Cadeia de suprimentos da indústria automotiva........................ 56

Figura 9 - Controles exercidos na cadeia de fornecimento...................... 62

Figura 10 - Representação cronológica das ações nos projetos estudados no caso 1

Figura 11 - Estrutura de projetos da empresa A1 


\section{LISTA DE QUADROS}

Quadro 1 - Resumo do sistema de pesquisa para revisão teórica................. 19

Quadro 2 - Estágios de desenvolvimento do produto............................... 41

Quadro 3 - Tipos de inovação dos projetos e a alavanca de inovação.......... 46

Quadro 4 - Características dos tipos de arranjos organizacionais ................ 51

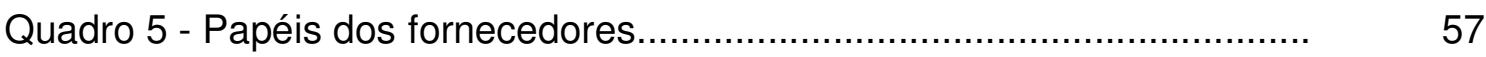

Quadro 6 - Métodos de pesquisa e critérios de escolha............................... 70

Quadro 7 - Síntese dos casos e dos levantamentos de campo realizados.... $\quad 77$

Quadro 8 - Divisão de etapas do projeto para fins de organização deste estudo

Quadro 9 - Relação de produtos e fornecedores avaliados por 79 segmento.

Quadro 10 - Dificuldades e aspectos positivos do caso 1

Quadro 11 - Dificuldades e aspectos positivos do caso 2

100

Quadro 12 - Análise dos prazos nos produtos considerados críticos para o projeto. 


\section{LISTA DE GRÁFICOS}

Gráfico 1 - Comparação entre capacidade de ação e nível de conhecimento de projeto.

Gráfico 2 - Evolução dos custos ao longo das fases de projeto.................. 38

Gráfico 3 - Comparativo de evolução projetada e real do projeto $1 \ldots \ldots \ldots \ldots \ldots . . . . .85$

Gráfico 4 - Comparativo de evolução projetada e real do projeto .2.......... 98 


\section{LISTA DE ABREVIATURAS}

AIAG - Automotive Industry Action Group

APQP - Advanced Product Quality Planing ou Planejamento Avançado da Qualidade do Produto

CAE - Computer aided engeneering ou engenharia auxiliada por computador

DCNP - Desenvolvimento colaborativo de novos produtos

DNP - Desenvolvimento de novos produtos

FMEA - Failure Mode and Effects Analysis ou Análise do Modo e Efeito de Falha Potencial

ISO/ TS 16949 - Certificação conforme normas técnicas que se aplica às organizações que produzem peças automotivas

PDP - Processo de desenvolvimento de produto

PPAP - Production Part Approval Process ou Processo de Aprovação de Peças de Produção

PSW - Part Submission Warrant ou Certificado de Submissão de Peça 


\section{SUMÁRIO}

1 INTRODUÇÃO

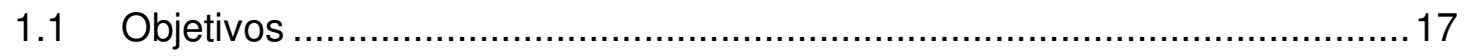

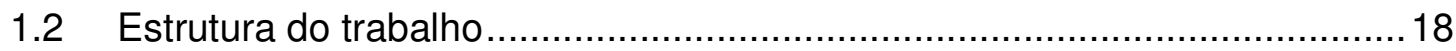

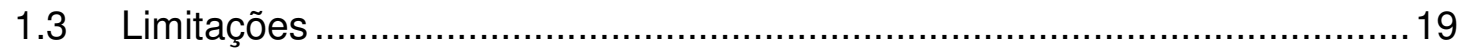

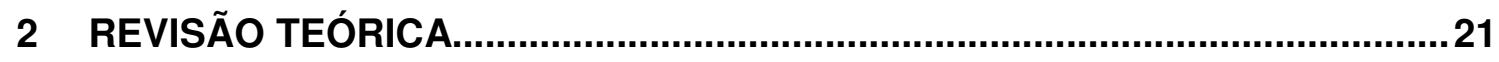

2.1 A gestão e validação do processo de desenvolvimento do produto - APQP e

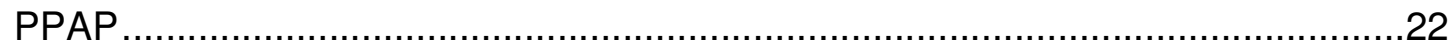

2.1.1 Planejamento Avançado da Qualidade do Produto (APQP) .................22

2.1.2 Processo de Aprovação de Peças de Produção (PPAP) ......................28

2.1.3 Uma análise da correlação entre a metodologia APQP e a ferramenta

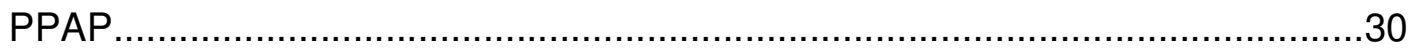

2.1.4 Ciclos de integração de solução de problemas ......................................31

2.2 O processo de desenvolvimento de produto ……......................................33

2.2.1 Gestão de projetos de desenvolvimento de produto................................36

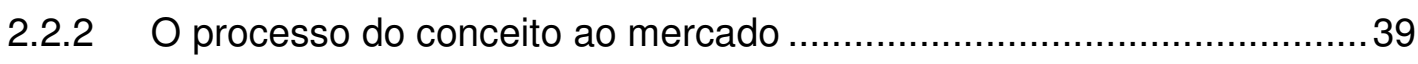

2.2.3 Tipos de projetos de desenvolvimento de produto …............................45

2.2.4 Aspectos de performance para o desenvolvimento de novos produtos. 47

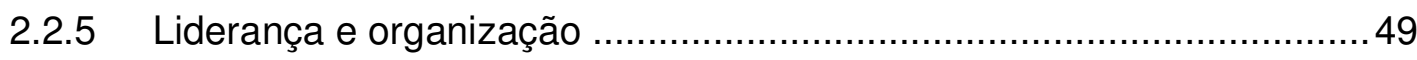

2.2.6 Fluxo da informação no processo de desenvolvimento de produto ........53

2.3 Cadeia automotiva e o desenvolvimento colaborativo ….............................56

2.3.1 Cadeia de fornecimento automotiva ……….................................... 
2.3.2 Desenvolvimento colaborativo de produto

2.3.3 Gestão do relacionamento com fornecedores .....................................59

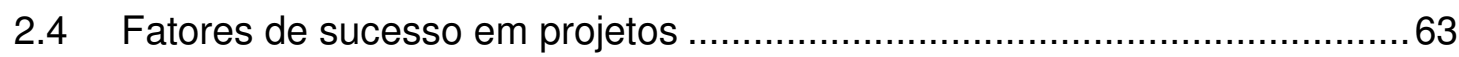

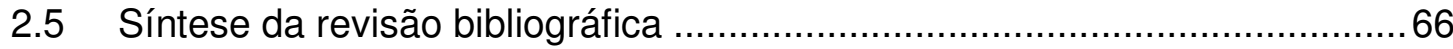

3 MÉTODO E PROCEDIMENTOS DE PESQUISA............................................69

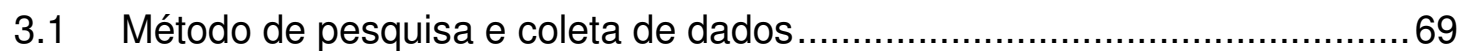

3.2 Descrição dos casos e instrumentos de pesquisa ......................................73

3.3 Método de coleta e análise dos documentos utilizados para o estudo .........78

3.3.1 Coleta de dados adicionais de outros projetos ....................................79

3.3.2 Entrevistas sobre o APQP para complementar entendimento do uso da

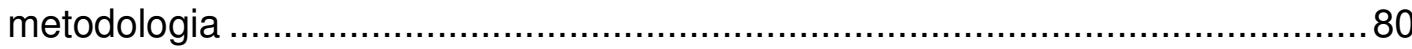

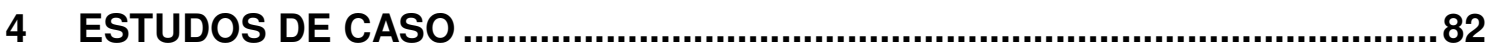

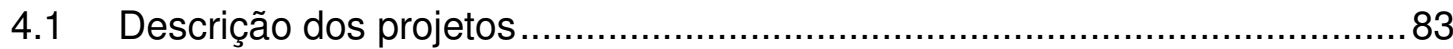

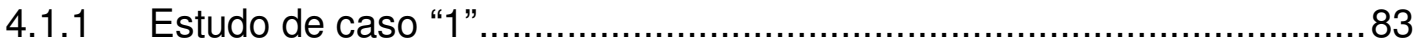

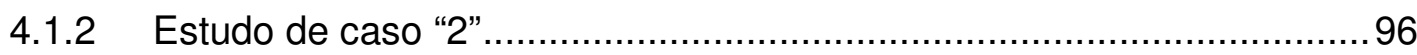

4.1.3 Análise complementar de outros projetos...........................................103

4.1.4 Entrevistas sobre o APQP: importância, vantagens e dificuldades para lidar com os problemas levantados nos casos ................................................ 104

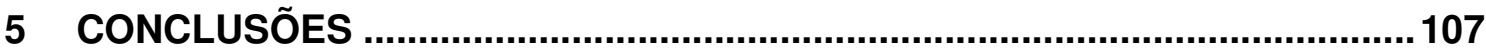

6 REFERÊNCIAS BIBLIOGRÁFICAS ......................................................112

7 APÊNDICE A - Questionário para pesquisa de campo .................................118

8 APÊNDICE B - Questionário para pesquisa de campo ..............................120 


\section{INTRODUÇÃO}

A indústria automotiva tem passado por uma evolução significativa nas últimas décadas, de forma que os três critérios clássicos de performance - qualidade, custos e entrega - têm se tornado armas estratégicas para o sucesso e, em alguns casos, para a sobrevivência das empresas (DONADA, 2001). Segundo Clark e Fujimoto (1991), a qualidade do lançamento dos produtos e o desempenho durante a sua existência está diretamente relacionada à gestão do processo de desenvolvimento dos mesmos. Segundo Rozenfeld et al. (2006), o processo de desenvolvimento do produto, em particular suas primeiras fases, é fundamental para determinar todo o custo do projeto, inclusive o custo do produto final.

Ainda para Clark e Fujimoto (1991), entre as promessas associadas ao sucesso do desenvolvimento de produto, estão o aumento na participação de mercado, novos clientes, redução de custos e aumento da qualidade. Isso deixa evidente a importância do desenvolvimento de produto para a competitividade das empresas.

Apesar do processo de desenvolvimento de produto ser tão importante e sua relevância já ter sido apontada por diversos autores (CLARK; FUJIMOTO, 1991; ROZENFELD et al., 2006), estes pesquisadores também apontam fragilidades das empresas em relação ao processo, mostrando que ele ainda não pode ser considerado dominado pelos seus executores e seu sucesso nem sempre é garantido. Clark e Fujimoto (1991) observam que muitas empresas podem ter um ou outro caso de sucesso, mas poucas alcançam consistente excelência no processo de desenvolvimento de produtos. Sendo assim, o processo de desenvolvimento de produto é, ainda hoje, um desafio e fonte de vantagem competitiva (Rozenfeld at al., 2006).

Ro et al. (2008) apontam que as montadoras americanas têm feito esforços no sentido de reorganizar os sistemas de desenvolvimento de produto, buscando referências nos sistemas dos japoneses e terceirizando cada vez mais peças e projetos dos veículos. 
Uma das maneiras de adquirir capacidades tecnológicas é através da terceirização de atividades (CHIESA; MANZINI, 1998). Os benefícios nos projetos feitos em parceria com fornecedores são ainda maiores quando estes se envolvem o mais cedo possível, pois, devido ao conhecimento e experiência que possuem, podem conduzir a melhorias no design do produto (TANG; QIAN, 2007; QUESADA et al. 2006).

A indústria automotiva é uma das indústrias que tem experimentado fortemente a onda de terceirizações nos últimos anos, fazendo com que as montadoras tenham que integrar e coordenar conhecimento mais fragmentado (BECKER; ZIRPOLI, 2003).

Os fornecedores de montadoras geralmente são detentores do conhecimento tecnológico relacionado ao produto, sendo este aproveitado pela montadora por meio de desenvolvimentos colaborativos (CLARK; FUJIMOTO, 1991).

O desenvolvimento de produto consiste em um processo que envolve competências, responsabilidades e a atuação de diversas áreas funcionais. A atuação de vários departamentos e mesmo diversas empresas juntas requer integração e comunicação, o que, por sua vez, necessita de estrutura para que possa ocorrer de maneira organizada (ZANCUL et al. 2005).

O trabalho aqui apresentado pretende discutir uma metodologia de trabalho que busca suprir algumas das necessidades de integração entre montadora e fornecedores no processo de desenvolvimento de produto (PDP), o Planejamento Avançado da Qualidade do Produto (APQP).

Em função da grandiosidade do setor, dos capitais investidos e das facilidades de acesso a tecnologias do mundo inteiro, a indústria automotiva é um campo frutífero para examinar fontes de superior performance no desenvolvimento de produto (CLARK; FUJIMOTO, 1991). Segundo Marx (1995), este é um dos setores que mais desenvolvem atividades de PD\&E (pesquisa, desenvolvimento e engenharia), sendo especialmente atraente para nosso tema de pesquisa. 
Segundo Clark e Fujimoto (1991), uma análise do desenvolvimento de produtos das montadoras Daimler, Toyota, BMW, Ford, Nissan e GM, proporciona uma rica fonte de informações sobre as diversas abordagens para a organização e gerenciamento.

Devido à relevância deste tema, algumas dinâmicas do setor automotivo, relacionadas às formas como as empresas se organizam para desenvolver e produzir novos produtos, têm sido muito estudadas nos últimos anos (BERTOLONI, 2004; DIAS, 2003; DONADA, 2001; SALERNO et al., 2003, 2009; RO et al., 2008; ZANCUL et al., 2006).

Cusumano e Takeishi (1991) alertam que o gerenciamento e a relação com o fornecedor são áreas cruciais para qualquer empresa que contrata parte do desenvolvimento e produção dos componentes. Isso ocorre devido à dependência do conhecimento que se cria fora da organização.

Considerando a importância do setor automotivo dentro da indústria, a influência que as montadoras possuem em relação às evoluções tecnológicas, estruturais e organizacionais sobre seus fornecedores diretos e indiretos (PADOVANI, 2007); somando a este fator a importância do desenvolvimento de produto e considerando que $70 \%$ do valor total do produto é gerado pelos fornecedores (QUESADA et al, 2006); e, por fim, considerando que o desenvolvimento de produto envolve uma complexa cadeia de interações e competências (ZANCUL, et al., 2006); conclui-se que se justifica a busca de um efetivo gerenciamento do fluxo de informações entre diversas áreas funcionais da empresa, fornecedores e clientes (ROZENFELD et al., 2006). Este gerenciamento é um requisito para se alcançar a qualidade na gestão do processo de desenvolvimento do produto. É dentro deste contexto que surge $O$ interesse das montadoras em desenvolver uma metodologia que gerencie, de maneira padronizada, o fluxo de informações entre fornecedores e os departamentos internos, a partir de uma série de atividades requeridas a serem executadas por estes diversos departamentos, em um cronograma geral do projeto. Esta é a função básica do APQP: estabelecer uma série de atividades que devem ser cumpridas em determinadas fases do processo de desenvolvimento do produto, determinando os responsáveis por cumprir estas atividades e seus prazos. Periodicamente, deve circular um relatório descrevendo as conformidades ou não 
conformidades no cumprimento a estas tarefas. O APQP foi uma metodologia elaborada, inicialmente, para atender às montadoras americanas (Chrysler, Ford e GM). Outras montadoras utilizam processos equivalentes, ainda que com outra formatação.

Existe vasta literatura sobre desenvolvimento de produto e sobre o processo de desenvolvimento colaborativo. A revisão de bibliografia realizada neste trabalho apresentada no quadro 1, capítulo 1.2 - encontrou pouca literatura publicada sobre a metodologia de trabalho aplicada nas montadoras de veículos americanas, o APQP (Planejamento Avançado da Qualidade do Produto). Publicações acadêmicas discutindo e avaliando o APQP, como feito neste trabalho, são também escassas, e a análise proposta ainda não foi estudada. No entanto, o APQP, bem como metodologias similares utilizadas em outras montadoras, é um instrumento que guia a gestão do PDP de inúmeras e relevantes empresas.

\subsection{Objetivos}

O objetivo deste trabalho é identificar condições que favoreçam a gestão do processo de desenvolvimento do produto realizada através da metodologia APQP, identificando fatores que possam ser relevantes ao longo do processo e possam influenciar o sucesso da sua gestão.

Torna-se importante contextualizar o que se entende por sucesso na gestão do processo dentro dos limites deste trabalho. Algumas das performances de projetos fundamentais que irão auxiliar a avaliação do sucesso do desenvolvimento do produto são: 1) prazo; 2) resultados de qualidade; 3) registros de documentação; 4) processo de aprendizagem durante o desenvolvimento (KERZNER,1987; CLARK; FUJIMOTO, 1991).

Para o desenvolvimento deste trabalho foi selecionada a indústria automotiva. Este setor, de fundamental importância para a indústria brasileira, representou $17,7 \%$ do PIB industrial do País em 2008 (ANFAVEA, 2009). O crescimento da indústria 
automotiva vem se mostrando expressivo, sendo que sua representação no PIB, em 2009, aumentou 48\% em comparação com o ano de 2003 (ANFAVEA, 2009). Para suportar este crescimento, as montadoras estão continuamente desenvolvendo produtos e tecnologias, buscando atrair clientes.

Considerando a proposta deste trabalho, que é identificar fatores que possam ser relevantes ao longo do processo e que possam influenciar o sucesso da sua gestão, entende-se que será também possível identificar alguns aspectos relacionados ao uso do APQP, como importância, dificuldades, vantagens e desvantagens de aplicar a metodologia para montadora e fornecedor.

A questão de pesquisa poderia ser assim formulada: Quais as condições para que o APQP possa ser considerado uma metodologia efetiva no gerenciamento do processo de desenvolvimento de novos produtos?

\subsection{Estrutura do trabalho}

Para o desenvolvimento da questão de pesquisa proposta foi realizada uma revisão bibliográfica sobre os seguintes temas:

1) APQP, ou Planejamento Avançado da Qualidade do Produto, e PPAP, ou Processo de Aprovação de Peças de Produção. O PPAP é um processo que está inserido em uma das cinco fases do APQP.

2) Processo de desenvolvimento de novos produtos, que irá se aprofundar em seis sub-tópicos: gestão de projetos de desenvolvimento de produto; etapas do processo do conceito ao mercado; tipos de projetos de desenvolvimento de produto; aspectos de performance; aspectos de liderança e organização; e fluxo de informação no processo de desenvolvimento de produto.

3) Interações entre fornecedores e clientes no processo de desenvolvimento de novos produtos, que irá se aprofundar em outros quatro sub-tópicos: cadeia 
automotiva; desenvolvimento colaborativo e gestão do relacionamento entre clientes e fornecedores.

4) Fatores de sucesso em projetos

Quadro 1 - Resumo do sistema de pesquisa para revisão teórica

\begin{tabular}{|c|c|c|c|c|}
\hline No pesquisa & fator limitante & palavras busca & bases de dados & temas selecionados \\
\hline pesquisa 1 & 10 anos & $\begin{array}{l}\text { product } \\
\text { development } \\
\text { automotive }\end{array}$ & $\begin{array}{l}\text { Scopus } \\
\text { Science Direct } \\
\text { Web of Science }\end{array}$ & $\begin{array}{l}\text { design colaborativo } \\
\text { fatores sucesso } \\
\text { aprendizagem } \\
\text { autores relevantes }\end{array}$ \\
\hline pesquisa 2 & 10 anos & $\begin{array}{l}\text { success factor } \\
\text { project } \\
\text { management }\end{array}$ & $\begin{array}{l}\text { revistas: International Journal of Project Management, Research Policy, R\&D } \\
\text { Management, Technovation, Communications of the Acm, Information \& } \\
\text { Management, MIS Quertely, The Academy of Management Journal (AMJ), } \\
\text { MANAGEMENT SCIENCE, Journal of Engineering and Technology } \\
\text { Management, IEEE Transactions on engeneering Management, International } \\
\text { Journal of Innovation Management, Project Management Journal }\end{array}$ & fatores criticos \\
\hline pesquisa 3 & relevantes & $\begin{array}{l}\text { product } \\
\text { development } \\
\text { automotive }\end{array}$ & $\begin{array}{l}\text { Scopus } \\
\text { Science Direct }\end{array}$ & $\begin{array}{l}\text { design colaborativo } \\
\text { fatores sucesso } \\
\text { aprendizagem } \\
\text { autores relevantes }\end{array}$ \\
\hline pesquisa 4 & relevantes & $\begin{array}{l}\text { lritical success } \\
\text { factor } \\
\text { project } \\
\text { management }\end{array}$ & $\begin{array}{l}\text { Scopus } \\
\text { Science Direct }\end{array}$ & fatores criticos \\
\hline pesquisa 5 & interesse & $\begin{array}{l}\text { artigos dentro dos } \\
\text { artigos lidos }\end{array}$ & diversas & diversas \\
\hline pesquisa 6 & $\begin{array}{l}10 \text { anos/ } \\
\text { relevantes }\end{array}$ & $\begin{array}{l}\text { innovation } \\
\text { product } \\
\text { development }\end{array}$ & $\begin{array}{l}\text { Scopus } \\
\text { Science Direct }\end{array}$ & $\begin{array}{l}\text { inovacao } \\
\text { desenvolvimento de } \\
\text { produto }\end{array}$ \\
\hline pesquisa 7 & $\begin{array}{l}10 \text { anos/ } \\
\text { relevantes }\end{array}$ & APQP & $\begin{array}{l}\text { Emerald } \\
\text { Science Direct } \\
\text { Journal of Product Innovation Management } \\
\text { Pro Quest }\end{array}$ & todos \\
\hline
\end{tabular}

Fonte: levantamento do autor

A pesquisa realizada para a elaboração da revisão bibliográfica apresentada neste trabalho está resumida no quadro 1. Foram utilizadas as principais bases de dados e buscadas palavras-chave para os temas de interesse, com restrições de buscas direcionadas pelo prazo e relevância dos trabalhos publicados. Foram também selecionados textos contidos em publicações lidas e consideradas relevantes para o trabalho de pesquisa.

Desta forma o trabalho segue, após a introdução, com a revisão bibliográfica já descrita, discussão metodológica, seguida pela apresentação e discussão dos casos, análise dos dados e recomendações.

\subsection{Limitações}


Esta dissertação irá se limitar a estudos de caso de empresas do setor automotivo brasileiro, mais precisamente sistemas abastecidos por fornecedores de primeiro nível, ou seja, que entregam seus produtos direto para uma montadora. Foi selecionada uma montadora situada na Grande São Paulo e, a partir dela, foram escolhidos dois projetos nos quais existe responsabilidade compartilhada entre a cliente e seus fornecedores.

O estudo busca aprofundar questões relativas ao método de gerenciamento do processo de desenvolvimento de produto, dentro das empresas fornecedoras e montadora, bem como entre as empresas.

Deve ser considerado que a relação de parceria entre montadoras e fornecedores está relacionada à estratégia de cada empresa, não somente a montadora, mas também ao posicionamento do fornecedor e também às capacidades tecnológicas do mesmo.

Por limitações inerentes ao método estudo de caso qualitativo, aqui aplicado na relação entre uma montadora e um fornecedor de primeiro nível, este trabalho não permite obter conclusões generalizadas sobre o assunto, que se apliquem a todas as montadoras de veículos, todos os mercados, tipos de produtos utilizados em veículos automotivos, bem como todos os fornecedores. Contudo, o trabalho aqui apresentado pode contribuir para discussões do tema desenvolvimento de produto, bem como para a metodologia de gerenciamento de produto atualmente utilizada pelas montadoras americanas, o APQP.

Poderia ser interessante estudar, a partir dos resultados obtidos nesta pesquisa, mercados com características diferentes do mercado brasileiro, como o americano, ou fornecedores com outras características, como aqueles ligados a outros tipos de componentes dentro da indústria automotiva, ou empresas de menor porte. Segundo Benito (2001), fornecedores com menor tecnologia ou sem apoio de subsidiárias fora do Brasil podem apresentar comportamentos diferentes na parceria de desenvolvimento de produto (BENITO, 2001). 


\section{REVISÃO TEÓRICA}

A partir dos objetivos de pesquisa descritos anteriormente, foi elaborada a revisão teórica que será mostrada a seguir. Este capítulo irá apresentar as metodologias utilizadas nas indústrias automobilísticas americanas para planejamento do desenvolvimento e para validação do produto e do processo. São elas: o APQP, Planejamento Avançado da Qualidade do Produto, e o PPAP, Processo de Aprovação de Peças de Produção. Serão, então, apresentados conceitos teóricos relacionados ao processo de desenvolvimento do produto e fatores de sucesso em projetos existentes na literatura.

As metodologias APQP e PPAP, utilizadas pelas montadoras americanas, irão orientar o levantamento de dados para a pesquisa de campo, e serão fundamentais para análises e questionamentos comparativos com conceitos teóricos, além de permitir a análise crítica de dados reais e discussão sobre o uso destas metodologias. O APQP permitirá a discussão sobre o processo de desenvolvimento, e o PPAP sobre o processo de validação final do produto e processo produtivo.

Os conceitos relacionados ao processo de desenvolvimento de produto serão utilizados para formar a estrutura do trabalho de pesquisa, possibilitando que seja organizado o que será pesquisado no estudo de caso e também delimitar as etapas do processo que farão parte do escopo do trabalho.

O levantamento de material de pesquisa utilizado para a revisão dos conceitos de desenvolvimento de produto e fatores de sucesso estão no quadro 1, apresentado no capítulo 1 deste trabalho.

Os fatores de sucesso irão auxiliar as discussões sobre questões que influenciam o sucesso dos esforços de projetos de desenvolvimento de produto. 


\subsection{A gestão e validação do processo de desenvolvimento do produto - APQP e PPAP}

O processo de desenvolvimento de produto requer uma gestão ampla e estruturada, que possa percorrer os aspectos importantes do desenvolvimento, considerando as etapas percorridas ao longo do projeto.

Ao final do desenvolvimento, é fundamental que o produto esteja validado e também que o processo esteja consistente, o que quer dizer que o produto terá sempre as características validadas no momento do desenvolvimento, preservando assim sua qualidade.

Para atender basicamente estas duas necessidades, a primeira, de gerenciar as atividades que devem ser cumpridas em cada etapa do projeto e, a segunda, de organizar os registros de validação do produto e do projeto, as montadoras americanas Ford e GM decidiram criar metodologias padronizadas: o APQP e o PPAP.

Estes documentos foram transformados em manuais obrigatórios para todos os fornecedores que se dispõem a desenvolver e fornecer qualquer tipo de peça para estas duas montadoras. O órgão responsável por desenvolver e distribuir estes materiais é o AIAG (Automotive Industry Action Group).

\subsubsection{Planejamento Avançado da Qualidade do Produto (APQP)}

Todas as montadoras de veículos gerenciam, de alguma forma, a qualidade no processo de desenvolvimento de produto dos seus fornecedores. As montadoras americanas que requisitam as práticas da ISO/ TS 16949, Ford, Chrysler e GM, criaram uma sistemática chamada APQP, cujos procedimentos foram descritos no manual publicado pelo AIAG (Automotive Industry Action Group). O APQP Advanced Product Quality Planning, ou Planejamento Avançado da Qualidade do Produto - é um método estruturado para definir e executar ações necessárias, 
permitir a comunicação entre as pessoas e atividades envolvidas no projeto. $O$ objetivo do APQP é acompanhar o planejamento e execução do processo de desenvolvimento e validação do produto e processo de produção.

Para atingir o objetivo descrito, o APQP estabelece uma série de atividades que devem ser cumpridas em determinadas fases do processo de desenvolvimento do produto. O APQP não substitui um bom cronograma de planejamento de projeto, com divisões em "gates" ou "milestones", usualmente utilizadas pelas empresas. Ele complementa este planejamento do projeto, descrevendo quais atividades de validação de produto e processo devem ser concluídas em cada uma destas etapas, com a finalidade de alinhar as informações entre cliente e fornecedor. O APQP é reconhecido como um planejamento de qualidade, pois seu objetivo é acompanhar atividades de desenvolvimento que garantam que, ao final do processo de desenvolvimento e ao longo da vida de produção, o produto tenha a qualidade necessária para desempenhar sua função no veículo. Daí o nome "planejamento avançado da qualidade do produto".

Figura 1 - Estágios do APQP

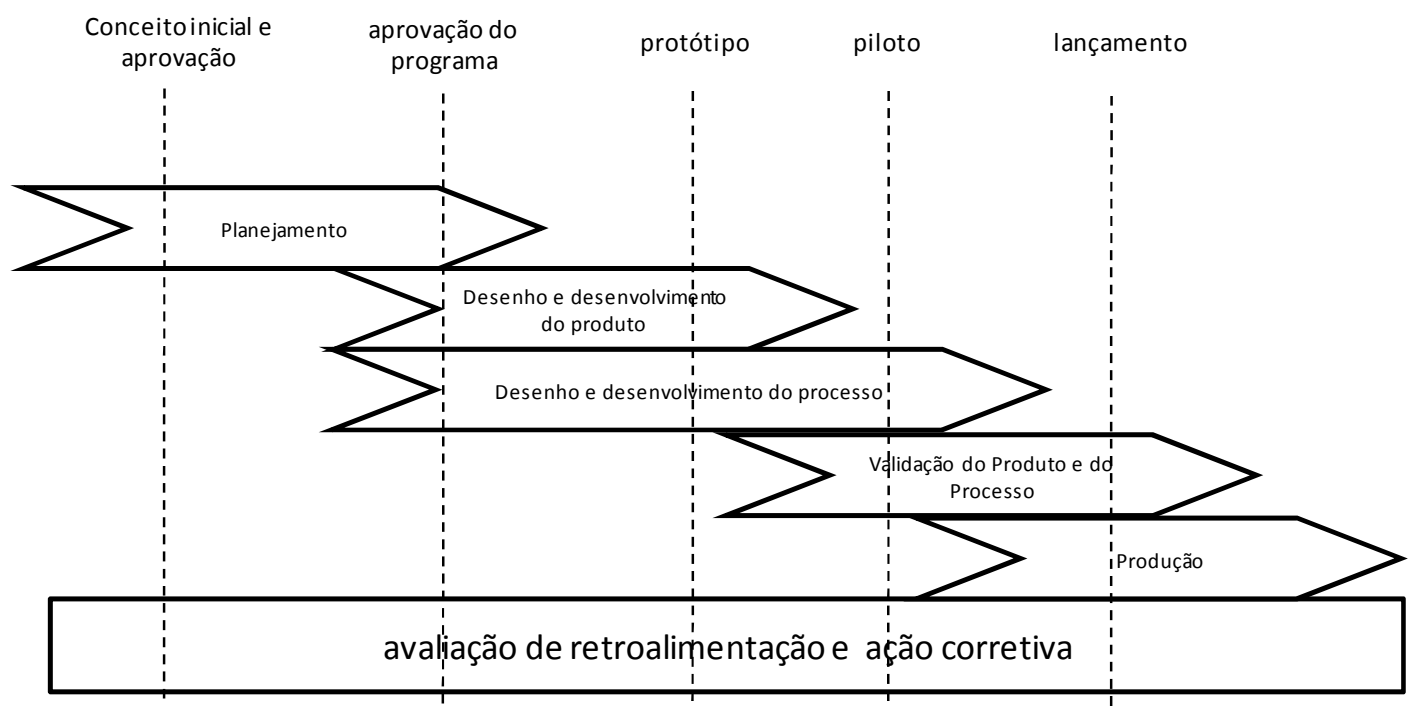

Fonte: CHRYSLER; FORD; GM (2008) 
O APQP possui uma estrutura básica, que será apresentada a seguir. Porém, esta estrutura fundamental pode ser adaptada para a linguagem e sistema de desenvolvimento de cada empresa, o que significa que as nomenclaturas, sistema de monitoramento, tratativas de equipes, reuniões, entre outros itens, são particulares de cada empresa.

\subsubsection{Estágio 1 - Planejamento}

Este estágio consiste em determinar as necessidades e expectativas do cliente, buscando planejar o programa de desenvolvimento do produto. Para isso, algumas atividades devem ser desenvolvidas nesta etapa, como descrito a seguir:

1. Pesquisa da "voz do cliente" (pesquisa de mercado, dados históricos de garantia e de qualidade);

2. Projeto de plano de negócio;

3. Dados de benchmarking do produto e do processo;

4. Pesquisa do produto e proposições do processo;

5. Estimativa de taxas da confiabilidade do produto;

6. Inputs do cliente;

7. Definição dos objetivos do projeto;

8. Definição dos objetivos da confiabilidade e da qualidade;

9. Preparação inicial da lista de material;

10. Preparação da carta de fluxo do processo;

11. Definição da lista preliminar de características especiais do produto e processo;

12. Definição do plano de garantia do produto; 
13. Análise crítica do plano de desenvolvimento com suporte da gerência.

\subsubsection{Estágio 2: Desenho e desenvolvimento do produto}

Neste estágio, as características do projeto são mais bem especificadas e começa a construção de protótipos, a fim de verificar se o produto está alinhado com expectativas do cliente e se o projeto segue as exigências daquele. As atividades a serem realizadas são as seguintes:

1. Elaboração do FMEA (análise do modo e efeito de falha potencial) de design;

2. Elaboração do projeto de montagem e de manufatura;

3. Verificação do projeto;

4. Revisões de projeto;

5. Construção do protótipo e do plano de controle do protótipo;

6. Elaboração dos desenhos de engenharia;

7. Definição das especificações da engenharia;

8. Definição das especificações dos materiais;

9. Desenhos e especificações;

10. Definição de novos equipamentos, ferramentais e dispositivos;

11. Definição de características especiais de processo;

12. Definição de requisitos de dispositivos de controles e testes;

13. Análise de viabilidade e compromisso da equipe e a sustentação da gerência. 


\subsubsection{Estágio 3: Desenho e desenvolvimento do processo}

Este estágio envolve o desenvolvimento do processo produtivo que assegure que as necessidades e exigências do cliente estejam atendidas. Atividades:

1. Definição dos padrões de embalagem;

2. Revisão do sistema de qualidade do produto / processo;

3. Conclusão da carta de fluxo do processo;

4. Definição do lay-out da planta;

5. Definição da matriz das características especiais;

6. Realização da FMEA de processo;

7. Elaboração do plano de controle de pré-lançamento;

8. Elaboração das instruções de processo;

9. Definição do plano de análise dos sistemas da medição;

10. Definição do plano de estudo preliminar de capacidade do processo;

11. Definição das especificações de embalagem;

12. Análise crítica do suporte da gerência.

\subsubsection{Estágio 4: Validação do produto e processo}

Neste estágio ocorre a validação do produto e processo através da corrida experimental ou trial run. O objetivo é assegurar que todas as atividades precedentes estejam realizadas de acordo com o planejamento, fornecendo os produtos de acordo com as exigências do cliente (especificações, volume da produção, etc.). Atividades: 
1. Execução da corrida experimental;

2. Avaliação do sistema de medição;

3. Avaliação preliminar da capacidade do processo;

4. Aprovação de peça de produção;

5. Realização dos testes de validação da produção;

6. Avaliação de embalagem;

7. Conclusão do plano de controle de produção;

8. Análise crítica do suporte da gerência e aprovação do planejamento da qualidade.

\subsubsection{Estágio 5: Produção, retroalimentação, avaliação e ação corretiva}

Após ter validado e executado o processo de produção, a eficácia do plano da qualidade de produto é avaliada no plano de controle de produção. Este estágio busca reduzir a variação do processo, assegurar solução de problemas e melhoria contínua, e retroalimentar o PDP. Atividades:

1. Análise e redução da variabilidade do processo;

2. Análise e correção do desempenho de produto (satisfação de cliente);

3. Análise dos serviços e entrega.

A expectativa de um desenvolvimento de produto acompanhado pelo APQP é de que, ao final do processo, todas as atividades previstas sejam concluídas. A realização destas atividades busca garantir que o produto tenha qualidade no seu lançamento e ao longo da sua vida de produção. Esta expectativa é suportada pela validação de produto e também de processo, sendo que a primeira busca a 
qualidade do produto analisado no momento do lançamento e a segunda busca a repetibilidade deste produto ao longo do tempo, sem degradação por questões de variação de processo.

Estas validações ficam registradas em um conjunto de documentos chamado de APQP, ou Planejamento Avançado da Qualidade do Produto.

Podemos observar que o APQP não está apenas restrito ao gerenciamento da qualidade. Um APQP bem acompanhado pode e deve considerar questões de tempo de entrega do projeto e produtividade do processo de desenvolvimento e de produção final.

Podemos observar que a adequada realização das atividades em cada estágio influencia diretamente os resultados de PDP, ou seja, a produtividade em cada estágio determina o desempenho do processo de desenvolvimento de produto.

O relacionamento entre estágios e atividades definidas no manual de APQP define uma sequência para que as atividades sejam realizadas e mostra que, após as atividades serem concluídas, as ações subsequentes podem ser iniciadas.

As atividades de um estágio proporcionam informações que são importantes para as ações subsequentes. Este é um fator relevante a ser considerado para avaliar as condições de simultaneidade entre tarefas e a probabilidade de retrabalho em cada estágio.

\subsubsection{Processo de Aprovação de Peças de Produção (PPAP)}

O APQP orienta e viabiliza o acompanhamento estruturado de todo o processo de desenvolvimento com o objetivo de realizar um trabalho preventivo, com foco na qualidade. A documentação de qualidade acompanhada através do APQP é organizada em um conjunto de documentos chamado PPAP que, ao final do processo, deve ser submetido à aprovação do cliente para o fornecimento de peças para montagem dos veículos. 
O PPAP deve conter os registros de projeto de engenharia, os requisitos de especificação e a evidência de que estes são adequadamente entendidos e atendidos pela organização. Deve, ainda, assegurar que a empresa possui potencial para fabricar o produto, atendendo consistentemente aos requisitos. Ele é realizado com base em uma corrida de produção real em uma taxa de produção definida. $O$ registro de aprovação do PPAP é realizado em um documento chamado PSW (Part Submission Warrant ou Certificado de Submissão de Peças).

$\mathrm{Na}$ prática, a elaboração do PPAP requer a aplicação de uma sequência de atividades e ferramentas descritas no manual da ISO/TS 16949. Estas ferramentas, por sua vez, são detalhadas em manuais também sugeridos pela ISO/TS 16949 ou segundo requisitos específicos de cada cliente (note que o fornecedor precisa atender o requisito de cada cliente, além da norma geral).

Elementos do PPAP:

1. Registros de projeto;

2. Autorização para mudanças de engenharia;

3. Aprovação do cliente;

4. FMEA de projeto;

5. Fluxograma de processo;

6. FMEA de processo;

7. Plano de controle;

8. Análise do sistema de medição;

9. Resultados dimensionais;

10. Análises de material;

11. Estudos iniciais de processo;

12. Documentação de laboratório qualificado; 
13. Aprovação de aparência;

14. Amostra de peças de produção;

15. Amostra padrão;

16. Auxílios de verificação do processo;

17. Requisitos específicos;

18. PSW - Autorização para submissão das peças.

(CHRYSLER; FORD; GM, 2006)

\subsubsection{Uma análise da correlação entre a metodologia APQP e a ferramenta PPAP}

Os elementos do Processo de Aprovação de Peças de Produção (PPAP) listados acima estão descritos ao longo das etapas do Planejamento Avançado da Qualidade do Produto (APQP), de forma que o acompanhamento do APQP deve suportar a elaboração do PPAP. O conjunto de documentos contidos no PPAP é o registro de que o produto atende às especificações previstas em desenho pela engenharia de produto e que o processo produtivo é capaz de repetir este produto com a mesma qualidade ao longo da sua vida. Sendo assim, o PPAP está focado em validação, e o APQP, no processo de construção, desde o conceito do produto até a validação e acompanhamento final, que é a sua última etapa.

Como o APQP está orientado para planejar a qualidade ao longo de todo o processo, ele busca garantir que todas as etapas incluam a preocupação com qualidade, por exemplo, as especificações definidas em desenho. Este enfoque está em sua segunda fase, que é o planejamento e desenvolvimento do produto. Nesta fase, diversas ferramentas de qualidade suportam esta demanda, como FMEA de projeto, construção de protótipos, entre outras. Após o planejamento do produto, o APQP prevê o planejamento e desenvolvimento do processo, suportado por diversas ferramentas de qualidade, previstas na fase 3. Por fim, segue a validação do produto 
e processo, que é a fase em que devem ser concluídos os documentos do PPAP. O APQP ainda possui a fase 5, que é a retroalimentação do sistema.

Sendo assim, o APQP possui um enfoque além do PPAP, pois busca garantir o andamento do processo focando na qualidade desde o conceito até o final do processo. Por sua vez, o PPAP está mais focado em garantir que, uma vez definido o produto, a peça entregue satisfaça as especificações.

\subsubsection{Ciclos de integração de solução de problemas}

Uma das questões centrais de gerenciamento efetivo do desenvolvimento está no elo entre conhecimento e informação existentes em diferentes departamentos e funções.

Clark e Fujimoto (1991) apresentam um modelo padrão de ciclo de solução de problemas, que consiste em quatro passos: reconhecimento do problema, geração de alternativas, avaliação e tomada de decisão (aceitar ou rejeitar a ação definida). A rejeição leva a um novo ciclo.

Clark e Fujimoto (1991) acreditam que cada uma das etapas do processo de desenvolvimento (protótipos, testes, revisão de desenhos, construção de ferramental, entre outras) pode ser caracterizada como um ciclo de solução de problemas.

Eles concluem que o que caracteriza uma performance notável na indústria automotiva não é o domínio de uma técnica em particular, mas o padrão de consistência no processo, estrutura, atitude e habilidades, que é por eles chamado de solução de problemas integrada.

Os autores apontam cinco dimensões da interface que determinam a natureza da integração, apresentadas no centro da figura 2, e padrões de atitudes que podem ser apresentadas para cada uma das dimensões. 
Apenas a intensificação da comunicação em uma única via pode trazer como consequência a redução do tempo total de solução de problema, mesmo quando este avanço de comunicação acontece ao final do ciclo.

Quando a frequência de informações aumenta em um único canal, permite às atividades de processos iniciarem-se antecipadamente, reduzindo tempo de solução de problemas.

Segundo os autores, o grupo de engenharia é mais relutante em entregar informações antecipadamente para a manufatura, se o ambiente é hostil e se mudanças de desenho podem provocar acusações de incompetência, por exemplo. Se for este o caso, a gerência necessita efetivar uma mudança fundamental de atitude através da organização tanto em engenharia como em manufatura, o que é uma tarefa difícil.

Figura 2 - Dimensões das soluções de problemas

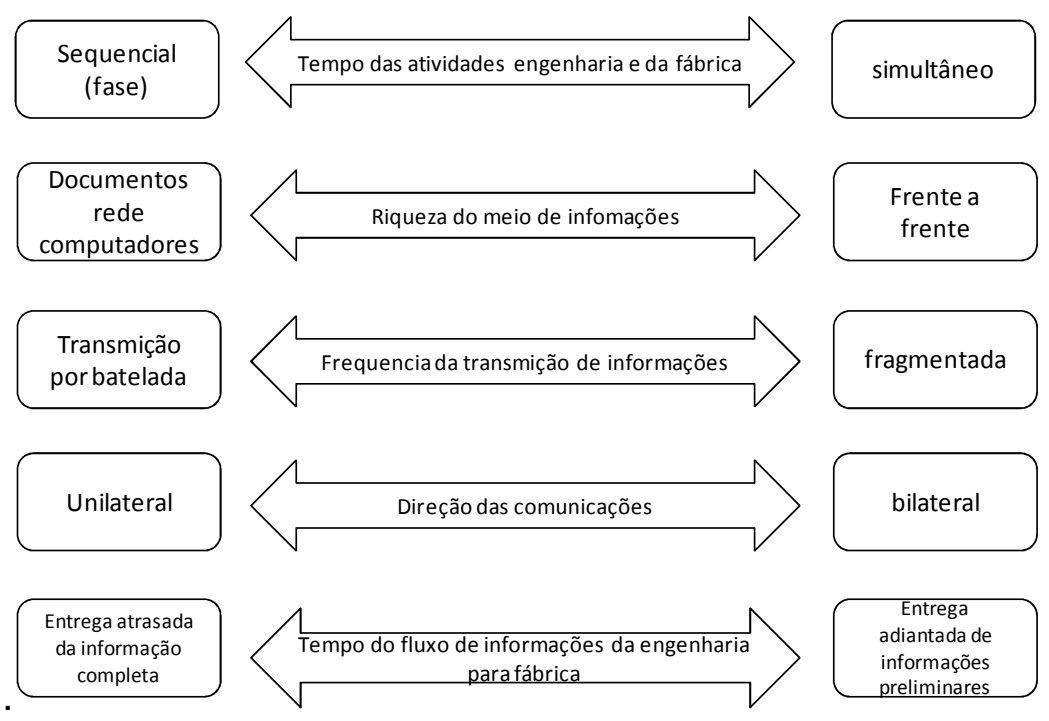

Fonte: Clark e Fujimoto (1991)

A comunicação bilateral cria a base para ajustes mútuos entre engenharia e manufatura. Esta comunicação depende da atitude e filosofia da empresa. Se a engenharia não faz concessões à manufatura, ou se esta nunca pode fazer o que é solicitado, a comunicação bilateral vai apenas aumentar a diversidade. 
A comunicação bilateral permite ajuste mútuo, fazendo que a engenharia leve em consideração as questões de processo, possibilitando produtos mais fáceis de manufaturar e menos custosos.

O contato antecipado auxilia a engenharia a realizar "certo na primeira vez".

A solução integrada de problemas acontece quando duas condições existem: rico, frequente e bilateral fluxo de informações e alto grau de atividades simultâneas.

\subsection{O processo de desenvolvimento de produto}

O desenvolvimento de produtos é considerado um processo de negócio cada vez mais crítico para a competitividade das empresas, principalmente com a crescente internacionalização dos mercados, aumento da diversidade e variação dos produtos oferecidos. (ROZENFELD et al., 2006)

Clark e Fujimoto (1991) resumem a finalidade do desenvolvimento de produto como um processo pelo qual, a organização transforma dados de oportunidade de mercado e possibilidades técnicas em um conjunto de informações para a produção comercial. Para toda esta transformação e trabalho devem ser levados em consideração velocidade e eficiência para que o desenvolvimento do produto, dentro da indústria automotiva, possa atender clientes e disputar com a concorrência. (CLARK; FUJIMOTO, 1991)

Para Dias (2003), o desenvolvimento de produto é uma atividade fundamental para a saúde e o futuro de qualquer empresa. A qualidade das atividades realizadas nesta etapa e o alinhamento com os objetivos da empresa serão refletidos ao longo de toda a vida do produto extrapolando, portanto, o período em que são realizadas as atividades do processo de desenvolvimento.

O desenvolvimento de produto também é abordado por alguns autores como um dos fatores de sucesso empresarial. Ernst (2002), apud Moreira (2005), defende que há 
cinco fatores de sucesso capazes de influenciar o desempenho empresarial: a) o processo de desenvolvimento de novos produtos; b) a organização desse processo; c) a cultura empresarial; d) o compromisso e a atuação da gestão do topo; e) a estratégia de desenvolvimento de novos produtos (DNP).

O desenvolvimento deve buscar algo mais do que custo e desempenho técnico do produto. Também são condições desejáveis para a competitividade: a qualidade do produto no atendimento aos diferentes requisitos dos clientes; colocação do produto no mercado o mais rápido possível, para aproveitamento adequado da janela de oportunidades, antecipando-se em relação à concorrência; e ainda, a facilidade de produzir e montar o produto e a criação e fortalecimento, a cada projeto, das capacitações requeridas para o desenvolvimento de produto no futuro (ROZENFELD et al., 2006)

Para Clark e Fujimoto (1991), o que diferencia empresas com desempenho superior no desenvolvimento de produtos é o padrão geral de consistência no sistema total de desenvolvimento de produto, incluindo estrutura organizacional, habilidades técnicas, processos de resolução de problemas, cultura e estratégia.

Em qualquer processo de desenvolvimento é necessário um planejamento para definir qual produto será oferecido, qual o desempenho esperado, quais especificações serão necessárias para atingir tal desempenho, como o produto será produzido, movimentado e armazenado. É necessário, ainda, definir onde estas atividades serão realizadas e quais destes serviços serão terceirizados (DIAS, 2003). O desenvolvimento também deve levar em consideração o número de componentes, níveis de custo, qualidade, objetivos de competição, mercado a ser atingido, e a ambiguidade da avaliação do cliente. (CLARK; FUJIMOTO, 1991)

Para Rozenfeld et al. (2006), desenvolver produtos consiste em um conjunto de atividades por meio das quais busca-se chegar às especificações de projeto de um produto, além de seu processo de produção, para que a manufatura seja capaz de executá-lo. Este processo deve levar em consideração as necessidades do mercado, as restrições tecnológicas e as estratégias competitivas e de produto da empresa. Ainda segundo Rozenfeld et al. (2006), uma importante parcela da 
vantagem competitiva conseguida pela manufatura japonesa nas últimas décadas advém do modo como os produtos são desenvolvidos e aperfeiçoados.

O modo como a empresa desenvolve produtos - ou seja, a sua estratégia de produto e como ela organiza e gerencia o desenvolvimento - é que determinará o desempenho do item no mercado e a velocidade, eficiência e qualidade do processo de desenvolvimento. Isto é, o desempenho do PDP depende de sua gestão (ROZENFELD et al., 2006).

Um processo eficaz e eficiente de desenvolvimento de produtos não é fácil de conseguir. Muitas empresas podem ter sucessos eventuais com um ou outro produto, mas são poucas as que alcançam êxito por meio de um processo de desenvolvimento eficiente de forma sustentada e conduzindo de modo planejado e articulado com estratégias competitivas da empresa (ROZENFELD et al., 2006)

O que distingue as empresas com excelência em desenvolvimento de produtos é o padrão de coerência e consistência em todo o processo de desenvolvimento, incluindo a estratégia, a estrutura organizacional, a sistematização das atividades, as habilidades técnicas, as abordagens para resolução de problemas, os mecanismos de aprendizagem e o tipo de cultura dominante. (ROZENFELD et al., 2006)

Uma pesquisa realizada por Cormican e Sulivan (2004) mostrou que os principais problemas identificados com o gerenciamento do processo de desenvolvimento de novos produtos estão relacionados a: falta de foco no cliente; pouco compartilhamento da visão entre áreas, principalmente aquelas com alto grau de especialização; gerenciamento deficiente de portfólio; deficiência na comunicação e transferência de conhecimento entre times sobre lições aprendidas em projetos anteriores.

Segundo Kerzner (1987), entre as razões pelas quais é difícil encontrar empresas com excelência em gestão de projetos estão: a) a gestão de projetos é relativamente nova para a maioria das empresas; b) a gestão de projetos é um sistema de gestão temporário, sobreposto na organização tradicional; c) empresas podem ser excelentes em gestão funcional, mas fracas em gestão de projetos e, reciprocamente, podem ser fracas em gestão funcional e fortes em gestão por 
projetos; d) maturidade em gestão por projetos não garante a excelência.

O carro é um produto com um grande número de componentes, funções e processos e seu desenvolvimento envolve milhares de pessoas durante vários meses. 0 mercado automotivo é grande, dinâmico e em processo de internacionalização. $O$ comportamento do cliente final é complexo e o ambiente turbulento (CLARK; FUJIMOTO, 1991). Isso faz com que o desenvolvimento de produto, um processo que já é complexo, se torne um desafio ainda maior.

\subsubsection{Gestão de projetos de desenvolvimento de produto}

O desenvolvimento de produto pode ser considerado um tipo de projeto específico. Segundo Kerzner (2006), projeto é um empreendimento com objetivo bem definido, que consome recursos e opera sob pressões, prazos, custos e qualidade, além de poder ser considerado uma atividade exclusiva da empresa. $O$ autor define ainda a gestão de projetos como "o planejamento, a programação e o controle de uma série de tarefas integradas de forma a atingir seus objetivos com êxito, para benefício dos participantes do projeto". Todas estas tarefas estão associadas ao projeto "desenvolvimento de produto".

Carvalho e Rabechini (2005) observam que projetos demandam tratamento diferenciado no que concerne ao seu gerenciamento, habilidades, técnicas e ferramentas específicas. Kerzner (1987) argumenta que, por este motivo, a preocupação com gestão de projetos tem crescido nas últimas décadas, pois foi percebido que se o projeto for corretamente desenvolvido, a empresa terá oportunidades de desempenhar melhores trabalhos em menos tempo e com menos recursos, aumentando a eficiência e produtividade da organização.

Para Tuman (1983), apud Pinto e Covin (1989), os projetos possuem os seguintes atributos: a) limitação de orçamento; b) limitação de tempo e estrutura de time; c) objetivos de performance e / ou conjunto de objetivos; d) uma série de atividades complexas e inter-relacionadas. 
Giard e Midler (1993) mostram que existe uma relação entre o tempo de desenvolvimento e os custos envolvidos em um projeto. Quanto maior o tempo, maiores os custos de oportunidade, mão-de-obra, entre outros.

Verganti (1999) e Giard e Midler (1993) argumentam que durante o desenvolvimento e a execução do projeto, os níveis de risco, bem como o grau de conhecimento sobre o projeto e também o grau de liberdade para mudança de parâmetros modificam-se consideravelmente, em cada fase. No início, as mudanças são simples e pouco custosas, mas não se tem muita certeza do que mudar. Em um estágio mais avançado, no qual se possui maior certeza de aspectos que precisam ser mudados, a mudança se torna custosa ou, às vezes, impossível. O projeto tem uma responsabilidade ainda mais intensa em uma produção em massa, na qual reduções ou aumentos de custos são multiplicados consideravelmente, o mesmo valendo para a qualidade dos produtos.

Gráfico 1 - Comparação entre capacidade de ação e nível de conhecimento de projeto

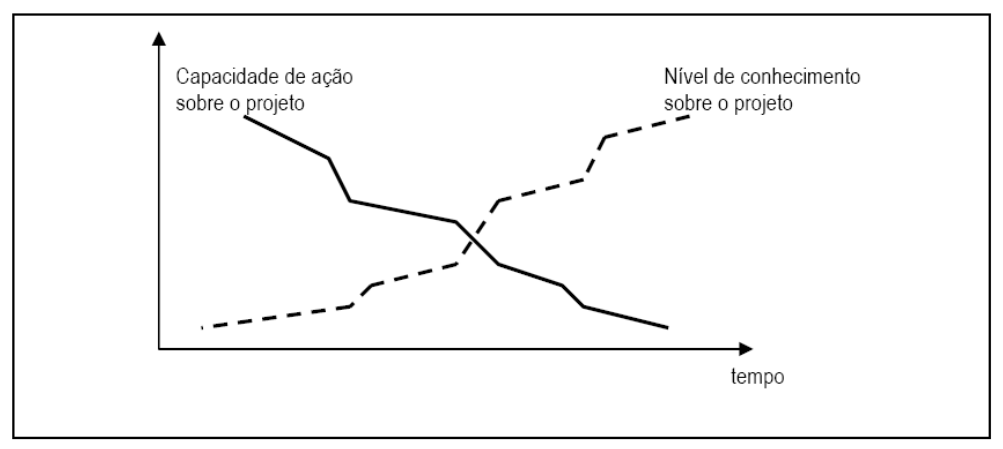

Fonte: Giard et al. (1991) apud Dias (2003)

Verganti (1999) considera que, no gerenciamento de um projeto, o desafio consiste em definir os melhores momentos de fixação de cada parâmetro, observar quais decisões devem ser tomadas no início e quais podem ser prorrogadas para fases posteriores do projeto, e ainda admitir a existência de imprevistos e a necessidade de possíveis modificações. É importante, ainda, construir uma capacidade de reação rápida e pouco custosa. As primeiras fases do projeto de desenvolvimento de produto são conhecidas como as que possuem responsabilidade pelo sucesso do projeto. 
Rozenfeld et al. (2006) afirmam que as escolhas de alternativas ocorridas no início do ciclo de desenvolvimento são responsáveis por cerca de $85 \%$ do custo do produto final. Ou seja, todas as outras definições e decisões a serem tomadas ao longo do ciclo de desenvolvimento após as fases iniciais determinam 15\% do custo. Rozenfeld et al. (2006) admitem ainda que são possíveis reduções de mais de 50\% no tempo de lançamento de um produto quando os problemas de projeto são identificados e resolvidos com antecedência, reduzindo o número de alterações posteriores e os tempos de manufatura e de resposta às necessidades do consumidor e, portanto, gerando competitividade.

Gráfico 2 - Evolução dos custos ao longo das fases de projeto

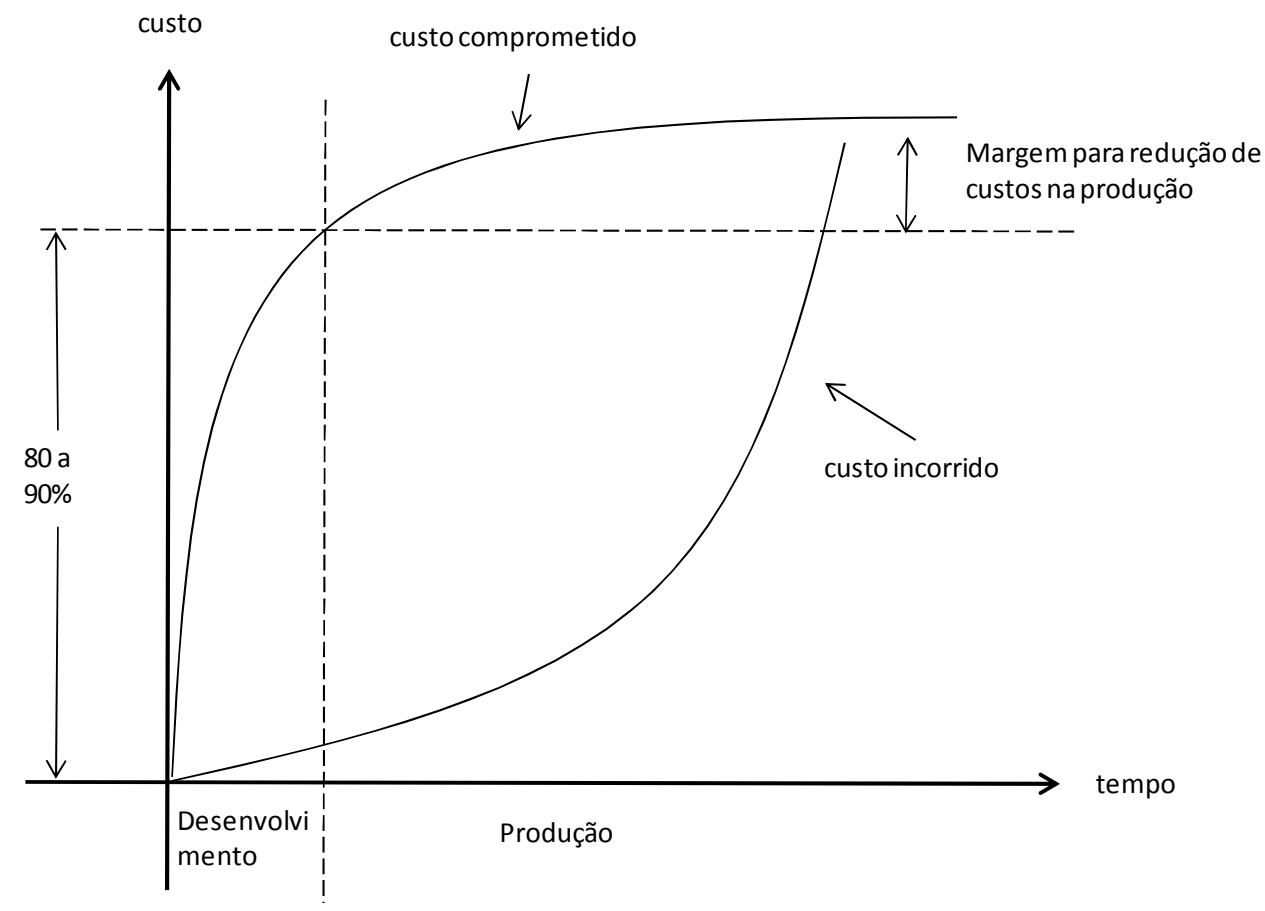

Fonte: Rozenfeld et al. (2006)

O gráfico 2 mostra a curva de comprometimento do custo do produto ao longo do desenvolvimento do projeto. As primeiras fases são decisivas para determinar custos.

1ํ fase - definição de materiais, tecnologia, processos de fabricação e principais soluções construtivas; 
2a fase - determinar tolerâncias, construir e testar protótipos, definir fornecedores, arranjos de processos, arranjo físico de produção, campanha de marketing, assistência técnica, etc. Momento em que se toma a maior parte das decisões significativas para a determinação do custo final do produto, em que se tem o maior grau de incerteza sobre o produto e suas especificações, sobre o processo de fabricação e mesmo se o produto terá sucesso no mercado.

Segundo Rozenfeld (2006) o PDP possui as seguintes características:

- Elevado grau de incerteza e riscos das atividades e resultados;

- Decisões importantes devem ser tomadas no início do processo, quando as incertezas são ainda maiores;

- Dificuldade de mudar as decisões iniciais;

- As atividades básicas seguem um ciclo interativo do tipo: projetar (gerar alternativas) - construir - testar - otimizar;

- Manipulação e geração de alto volume de informações;

- As informações e atividades provêm de diversas fontes e áreas da empresa e da cadeia de suprimentos;

- Multiplicidade de requisitos a serem atendidos pelo processo, considerando todas as fases do ciclo de vida do produto e seus clientes.

\subsubsection{O processo do conceito ao mercado}

Cooper (2008) propõe uma estrutura de desenvolvimento contendo etapas de desenvolvimento seguidas por "gates" de decisão. Ele a nomeia Stage-gate®.

Clark e Fujimoto (1991) propõem quatro estágios de desenvolvimento:

- Desenvolvimento do conceito do produto; 
- $\quad$ Planejamento do produto;

- $\quad$ Engenharia do produto;

- $\quad$ Engenharia do processo.

Cada empresa realiza os elos entre estas etapas e as gerencia de uma maneira. Criar e gerenciar estes elos eficientemente depende de 1) habilidade de a empresa criar canais de comunicação; 2) atitudes de cooperação; 3) habilidades dos engenheiros

Figura 3 - Stage-gate®: cinco estágios e cinco pontos de decisão da descoberta à fase de pós-lançamento

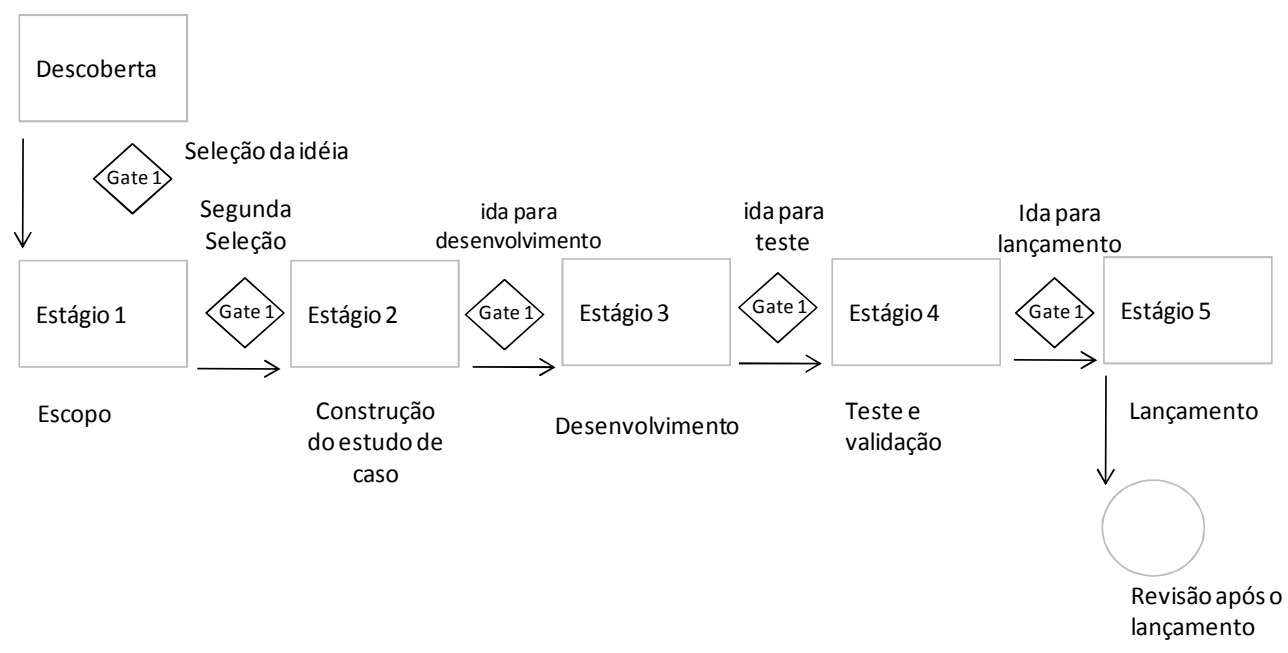

Fonte: Adaptado de Cooper (2008)

\section{Desenvolvimento do conceito do produto}

\section{Conceito total do veículo como uma arma competitiva}

No estágio de geração do conceito é necessário levantar informações sobre as futuras necessidades do mercado, possibilidades tecnológicas, viabilidade econômica, entre outras. Estas informações são traduzidas em descrição do produto e são, posteriormente, levadas aos clientes para serem experimentadas. 
O gerenciamento das informações que são consideradas para o conceito do produto é muito importante. Três fontes de informações são fundamentais: informações de marketing, planos estratégicos e resultados de engenharia.

Quadro 2 - Estágios de desenvolvimento do produto

\begin{tabular}{|c|c|c|c|c|}
\hline & Estágio & Foco & Input & Output \\
\hline \multirow[b]{2}{*}{ Planejamento } & $\begin{array}{l}\text { Estudo } \\
\text { Conceito }\end{array}$ & $\begin{array}{l}\text { Criação de conceito } \\
\text { básico do produto, } \\
\text { incluindo objetivos do } \\
\text { cliente e elementos } \\
\text { distintos } \\
\end{array}$ & \begin{tabular}{|l} 
Informação das \\
necessidades do cliente, \\
competidores, \\
desenvolvimento \\
tecnológico \\
\end{tabular} & $\begin{array}{l}\text { Declaração escrita do } \\
\text { conceito do produto }\end{array}$ \\
\hline & $\begin{array}{l}\text { Planejamento } \\
\text { do Produto }\end{array}$ & $\begin{array}{l}\text { Conjunto de objetivos, } \\
\text { performance, custos, } \\
\text { estilo estabelecido, } \\
\text { escolha de componentes } \\
\text { e esquema, determinação } \\
\text { de investimento } \\
\text { necessário e retorno }\end{array}$ & $\begin{array}{l}\text { Conceito do produto, } \\
\text { informação, dados } \\
\text { técnicos, idéias de estilo, } \\
\text { desenvolvimento de } \\
\text { engenharia avançada }\end{array}$ & $\begin{array}{l}\text { Especificações de } \\
\text { Perfomance detalhada: } \\
\text { modelo de material, plano } \\
\text { de componente, esquema }\end{array}$ \\
\hline \multirow[b]{2}{*}{ Engenharia } & $\begin{array}{l}\text { Engenharia de } \\
\text { produto }\end{array}$ & $\begin{array}{l}\text { Criação de uma escala } \\
\text { completa de protótipos, } \\
\text { que atendem o conceito e } \\
\text { o plano }\end{array}$ & Plano do produto & $\begin{array}{l}\text { Trabalho com protótipos; } \\
\text { desenhos de engenharia } \\
\text { detalhada (ou dados de } \\
\text { CAD) }\end{array}$ \\
\hline & $\begin{array}{l}\text { Engenharia de } \\
\text { Processo }\end{array}$ & $\begin{array}{l}\text { Processos e ferramentas } \\
\text { para produção comercial } \\
\text { do veículo }\end{array}$ & $\begin{array}{l}\text { Plano do produto: } \\
\text { desenhos e } \\
\text { especificações de } \\
\text { engenharia }\end{array}$ & $\begin{array}{l}\text { Esquema da planta, } \\
\text { desenho das ferramentas } \\
\text { e equipamentos, produção } \\
\text { das ferramentas, } \\
\text { equipamentos, folhas de } \\
\text { fluxo }\end{array}$ \\
\hline
\end{tabular}

Fonte: adaptado de Clark e Fujimoto, 1989

Informações de marketing

Podem ser realizadas diretamente pelos criadores de conceito, buscando informações no mercado, vendas, etc., ou indiretamente por especialistas ou grupos de marketing. As informações são enviadas aos criadores de conceito.

\section{Plano estratégico}

Planos estratégicos de longo alcance, também chamados de plano de ciclo, devem ser realizados para toda a extensão de produtos. Devem ser criados e revisados periodicamente para assegurar a coordenação do tempo de lançamento de novos produtos através de projetos. Os tempos de projetos devem, então, ser estabelecidos, com um critério estratégico. 
Tendências de mercado, disponibilidade de tecnologias e componentes, pesquisas, tudo deve ser levado em consideração na criação do ciclo de produtos, que normalmente tem um horizonte de 10 anos.

\section{Inputs tecnológicos}

Os avanços tecnológicos podem moldar o desenvolvimento do conceito de produtos. Reciprocamente, os conceitos de produto podem direcionar o desenvolvimento de tecnologias.

\section{Planejamento do produto}

O conceito do produto deve se traduzir em suposições sucessivamente mais concretas, incluindo especificações, custos, objetivos de desempenho, escolha de componentes, estilo e layout para a engenharia detalhada de produto.

Os dois maiores desafios são alcançar a excelência no planejamento do produto sob a ótica de consciência interna e externa. A consciência externa está em refletir cuidadosamente o conceito do que o cliente considera atrativo em especificações, componentes, estilo e layout. A consciência interna é a compatibilidade entre as escolhas de especificações, componentes, estilo e layout.

O planejamento do produto envolve uma complicada teia de negociações entre conceito, especificações, escolha de componentes, objetivos de custo, layout e estilo. Para orquestrar estas variáveis, a comunicação e a coordenação entre departamentos, plantas e unidades, é muito importante. O modo como a empresa divide e nomeia tarefas pode ter uma influência crítica para a integridade do produto.

\section{Engenharia do produto}

Mesmo após a engenharia detalhada do produto ter sido aprovada pela gerência sênior e as definições do produto estarem completas, pode haver tensões e conflitos nas definições realizadas, como especificações inadequadas, conflitos de objetivos, entre outros. A engenharia de produto precisa, então, enfrentar inúmeros ajustes e negociações nos componentes e subsistemas. 


\section{$\underline{\text { Organizando a engenharia de produto }}$}

Como consequência da complexidade, as empresas dividem os projetos em partes gerenciáveis. Por exemplo, há grupos de trabalho de engenheiros internos, contratados e fornecedores. Equipes de desenho e testes normalmente também são separadas. Corpo, chassi e power-train costumam ser organizados em departamentos diferentes.

\section{Desenvolvimento do conceito e a engenharia de produto}

O conceito total do veículo necessita ser introduzido e detalhado em cada um dos seus componentes, o que requer uma proximidade entre líderes do conceito do produto e engenheiros do produto. Entretanto, esta proximidade é relativamente rara.

Para Clark e Fujimoto (1991), existem pelo menos duas formas de alcançar uma integração próxima entre conceito e detalhamento do produto: por meio de líderes de projeto e também pela tradição de engenharia do produto. A integração promovida por líderes é refletida ao nível dos engenheiros. Já projetos de produtos estáveis ao longo de diversas gerações e modelos, com conhecimento compartilhado pelos engenheiros, permitem uma integração sem necessitar ênfase no processo de comunicação entre conceito e engenharia.

\section{Construindo e testando protótipos}

Os testes são inicialmente realizados com simuladores em software tipo CAE (computer aided engeneering), porém os testes em modelos físicos são importantes para simular a experiência de clientes cada vez mais sofisticados.

Os testes com protótipos devem refletir as necessidades de design e a sua importância reside no fato de que, se os problemas não forem identificados e tratados no início do desenvolvimento, poderão ser identificado somente nas corridas pilotos, na curva de aceleração ou, ainda, após o lançamento.

Mudanças de engenharia 
Qualquer mudança de engenharia após a aprovação inicial do produto requer um processo de gestão em que a mudança deve ter aprovações internas e do fornecedor, tanto no aspecto de manufatura do novo produto, como no custo.

Segundo Clark e Fujimoto (1991), algumas empresas americanas gerenciam o processo de mudança preocupadas com custo e risco. O processo de mudança envolve diversas assinaturas e níveis de aprovação antes que possa ser implementado. As empresas japonesas possuem uma abordagem diferenciada. $\mathrm{O}$ processo é menos burocrático e focado mais na agilidade da implementação que em verificações. Os engenheiros realizam mudanças mais rapidamente quando o custo e a pressão por tempo é baixa. Eles reduzem o número de mudanças devido a erros de negligência ou falta de comunicação, então as mudanças são realizadas para valorizar o produto.

Quando a mudança se faz necessária, os engenheiros a realizam rapidamente, utilizando negociação informal no nível de operação para evitar excessivo uso de papel.

\section{Engenharia do processo}

As informações de desenho são convertidas em um conjunto de informações, como ferramentas, equipamentos, softwares de controle de processo, habilidades dos operários, procedimentos padrão de operação, que serão desdobrados no processo de operação neste estágio. Neste momento, podem ocorrer tensões resultantes da demanda pela performance do produto e conforto ou facilidade para a produção. A efetividade do processo de engenharia depende da habilidade de interação entre os engenheiros de produto e fábrica.

Simultaneidade de engenharia de produto e processo

A engenharia simultânea permite reduzir o tempo de desenvolvimento, pois as engenharias de produto e de processo podem trabalhar ao mesmo tempo. Porém, se este processo não for bem sincronizado, por exemplo, se ocorrer uma mudança em um desenho de uma peça cujo ferramental já está desenvolvido, pode haver confusão ou ineficiência no processo. 
Uma abordagem paralela enfatiza, então, a necessidade e importância da coordenação entre engenharia de produto e processo.

Comunicação entre produto e processo

Apenas uma comunicação antecipada entre engenharias de produto e processo pode não facilitar, ou ainda complicar, a interação entre estas partes, pois pode tornar ainda mais evidente e inconveniente uma série de modificações de produto inerentes ao processo.

A atitude orientada ao cliente, responsabilidade compartilhada e confiança mútua entre as partes parece ser o fundamento básico para uma comunicação efetiva.

Engenharia de processo e o volume de produção

O piloto de produção proporciona a oportunidade de analisar tanto o desenho do produto como o processo de produção.

Quando os equipamentos e ferramentas são qualificados e o processo apresenta aceitação no nível de performance, o início da produção é oficialmente autorizado.

\subsubsection{Tipos de projetos de desenvolvimento de produto}

Com a finalidade de avaliar fatores que podem ser relevantes para gestão do processo colaborativo, são apresentadas, a seguir, algumas abordagens relacionadas ao grau de inovação do produto em desenvolvimento.

Rozenfeld et al. (2006) propõem a abordagem de tipos de projetos a partir do grau de inovação e do gerenciamento do projeto:

- $\quad$ Projetos radicais: são os que envolvem significativas modificações no projeto do produto ou do processo existente. Como neste projeto são incorporadas novas tecnologias e materiais, eles, normalmente, requerem um processo de manufatura também inovador; 
- $\quad$ Projetos plataforma ou próxima geração: normalmente representam alterações significativas no projeto do produto e/ou do processo, sem a introdução de novas tecnologias ou materiais, mas representam um novo sistema de soluções para o cliente;

- Projetos incrementais ou derivados: envolvem projetos que criam produtos e processos que são derivados, híbridos ou com pequenas modificações em relação aos projetos já existentes;

- $\quad$ Projetos follow-source são projetos que chegam da matriz ou de outras unidades da companhia e que não requerem alterações significativas;

- Projetos de pesquisa avançada que têm por objetivo criar conhecimento para projetos futuros.

Quadro 3 - Tipos de inovação dos projetos e a alavanca de inovação

\begin{tabular}{|c|c|c|c|c|c|c|}
\hline \multirow{2}{*}{ Tipos de inovação $\quad$ Alavancas } & \multicolumn{3}{|c|}{ Alavancas dos modelos de Negócios } & \multicolumn{3}{|c|}{ Alavancas Tecnológicas } \\
\hline & \begin{tabular}{|c|}
$\begin{array}{c}\text { Proposição de } \\
\text { valor }\end{array}$ \\
\end{tabular} & $\begin{array}{l}\text { Cadeia de } \\
\text { valor }\end{array}$ & cliente-alvo & $\begin{array}{c}\text { Produtos e } \\
\text { serviços }\end{array}$ & \begin{tabular}{|c|} 
Tecnologia de \\
processos
\end{tabular} & $\begin{array}{c}\text { tecnologia } \\
\text { capacitadora }\end{array}$ \\
\hline Incrementais & \multicolumn{6}{|c|}{ Mudanças pequenas em uma ou mais das seis alavancas } \\
\hline $\begin{array}{l}\text { Semi-radicais } \\
\text { Orientadas por modelo de negócios }\end{array}$ & \multicolumn{3}{|c|}{$\begin{array}{l}\text { Mudança significativa em uma ou mais das } \\
\text { três alavancas }\end{array}$} & \multicolumn{3}{|c|}{$\begin{array}{l}\text { Mudanças pequenas em uma ou mais } \\
\text { das três alavancas }\end{array}$} \\
\hline $\begin{array}{l}\text { Semi-radicais } \\
\text { Orientadas por tecnologia }\end{array}$ & \multicolumn{3}{|c|}{$\begin{array}{l}\text { Mudança pequena em uma ou mais das } \\
\text { três alavancas }\end{array}$} & \multicolumn{3}{|c|}{$\begin{array}{l}\text { Mudanças significativas em uma ou mais } \\
\text { das três alavancas }\end{array}$} \\
\hline Radicais & \multicolumn{3}{|c|}{$\begin{array}{l}\text { Mudança significativa em uma ou mais das } \\
\text { três alavancas }\end{array}$} & \multicolumn{3}{|c|}{$\begin{array}{l}\text { Mudanças significativas em uma ou mais } \\
\text { das três alavancas }\end{array}$} \\
\hline
\end{tabular}

Fonte: Davila et al. (2007)

Davila et al. (2007) propõem três tipos básicos de modificação no produto a partir do grau de inovação: incrementais, semi-radicais (orientados por tecnologia ou modelos de negócios) e radicais.

É possível observar que existe semelhança entre as abordagens de Rozenfeld et al. (2006) e Davila et al. (2007) do ponto de vista de tipos de inovação. Neste trabalho utilizaremos a abordagem de Rozenfeld et al. (2006), pois as alavancas para a inovação apresentadas por Davila et al. (2007) não fazem parte do escopo desta obra. 


\subsubsection{Aspectos de performance para o desenvolvimento de novos produtos}

Clark e Fujimoto (1991) abordam três temas básicos para o desenvolvimento de um produto eficiente:

1. O desenvolvimento de um produto como uma simulação da experiência do cliente;

2. Consistência do detalhe no desenvolvimento;

3. Integridade do produto.

1 - O desenvolvimento do produto como uma simulação da experiência do cliente: significa o quão bem o grupo de desenvolvimento simula os objetivos do cliente e é crítico para a efetividade dos esforços do desenvolvimento de produto.

2 - Consistência do detalhe: gerentes efetivos precisam prestar atenção no sistema total de desenvolvimento de produto e também atividades detalhadas ao mesmo tempo, a fim de produzir produtos de sucesso.

3 - Integridade do produto: a integridade possui uma dimensão externa e uma interna. A primeira se refere à função e estrutura do produto; se as partes se adequam, se os componentes combinam. A dimensão externa se refere a quão bem o produto, as funções e a estrutura se adequam aos objetivos do cliente.

Segundo Clark e Fujimoto (1991), a criação de novos produtos tem sido central desde o início da indústria automotiva. Considerando que a competição, novas tecnologias e a nova geração de compradores criaram um ambiente turbulento nas empresas automotivas, as vantagens vão para as empresas que podem oferecer a maior variedade de novos produtos, com maior performance e maior apelo geral. (CLARK; FUJIMOTO, 1991):

Ainda segundo Clark e Fujimoto (1991), as empresas japonesas e americanas apresentam diferentes capacidades para o mercado, com diferentes abordagens, mas estão, ambas, buscando aprimorar o desenvolvimento de produto. 
A pesquisa realizada por Clark e Fujimoto (1991) em 29 projetos de 20 empresas mostra que as empresas japonesas conseguem até o dobro de produtividade no processo de desenvolvimento de produto e que podem desenvolver produtos equivalentes um ano mais rápido que as americanas.

Kerzner (1987) relata alguns aspectos que devem ser atendidos para se alcançar a excelência em gestão de projetos:

1. Projeto dentro do tempo;

2. Atendendo o custo ou orçamento previsto;

3. Adequado ao desempenho ou performance desejada;

4. Dentro da aplicação original ou mudanças acordadas;

5. Sem afetar a cultura da empresa ou valores corporativos;

6. Bem documentado, com avaliação endereçada.

Midler (1993) apud Dias (2003) aponta que a importância do fator tempo no desenvolvimento depende da situação concorrencial na qual a empresa se encontra. A urgência em lançar um produto em um nicho ou em outro depende da movimentação das empresas concorrentes.

Para Clark e Fujimoto (1991), três saídas do processo de desenvolvimento de produto afetam a capacidade deste em atrair e satisfazer clientes:

a) A primeira é chamada qualidade total do produto (TPQ - total product quality) que é a extensão na qual o produto satisfaz os requerimentos do cliente. Pode ser dividida em dois níveis:

a. A qualidade do desenvolvimento do projeto;

b. A habilidade de produzir este produto, que é a qualidade da conformidade.

b) A segunda dimensão crítica é o lead time; o quão rápido a empresa consegue se mover do conceito até chegar ao mercado. O lead time afeta a execução do projeto e a aceitação deste no mercado. O planejamento e criação devem ocorrer antes do 
projeto e a qualidade destas atividades depende fortemente de quão bem 0 planejamento prevê as necessidades dos futuros clientes e produtos concorrentes. $O$ lead time pode afetar a atratividade do produto pela precisão da previsão.

c) A terceira dimensão do desempenho é a produtividade, ou seja, o nível de recursos para levar o projeto do conceito até produto comercializável. Isto inclui horas trabalhadas, material utilizado para construção de protótipo, entre outros. Em função dos pequenos limites de intervalos de mudança de modelo nesta indústria, o lead time pode mudar a percepção de novidade do novo modelo.

As vantagens em produtividade podem ser utilizadas de diferentes maneiras, como para maior renovação dos produtos ou mesmo lançamento em linhas mais abrangentes. (CLARK; FUJIMOTO, 1991):

Figura 4 - Integração entre lead time, qualidade e produtividade

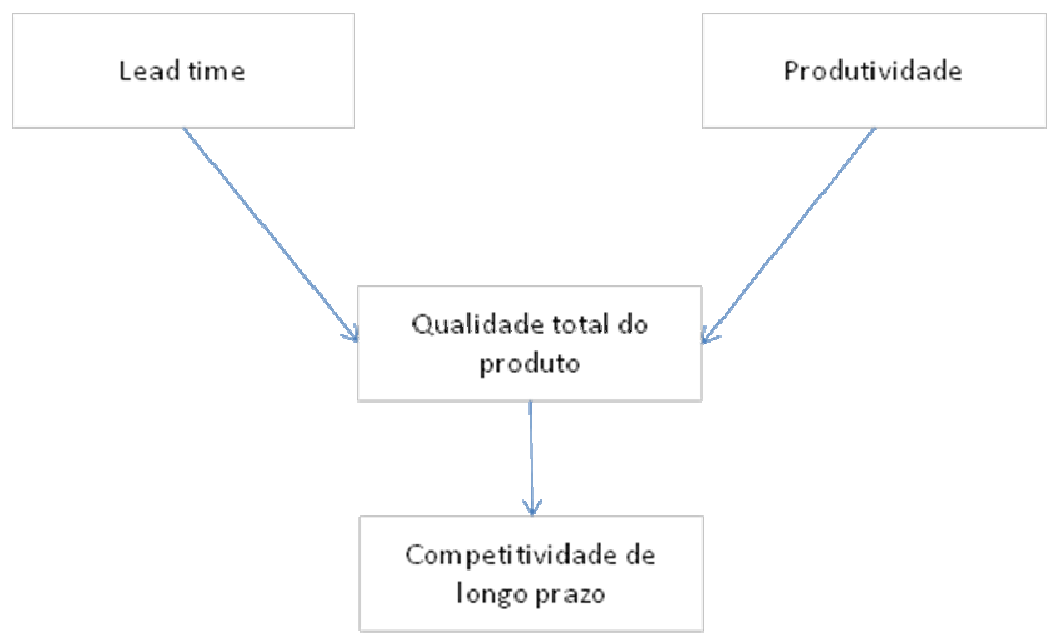

Fonte: Clark e Fujimoto (1991)

\subsubsection{Liderança e organização}

A organização das atividades de desenvolvimento de produto refere-se à forma como os indivíduos que estão trabalhando estão ligados individualmente ou em grupos, de maneira formal ou informal. As maneiras mais tradicionais de realizar 
essa ligação organizacional ocorrem por meio de alinhamento de funções, de projetos, ou uma combinação de ambos.

Segundo Rozenfeld et al. (2006), as funções clássicas envolvidas em PDP são: marketing, engenharia e manufatura, sendo comum existirem subdivisões, por exemplo: estratégia de produto, engenharia de processo, engenharia industrial, entre outras.

Figura 5 - Formas de organização do processo de desenvolvimento de produto

Estrutura funcional:

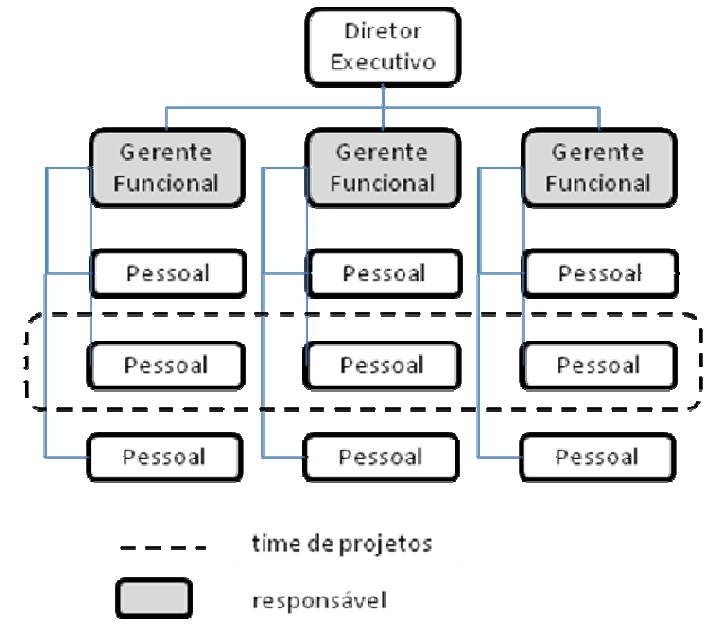

Estrutura por projeto:

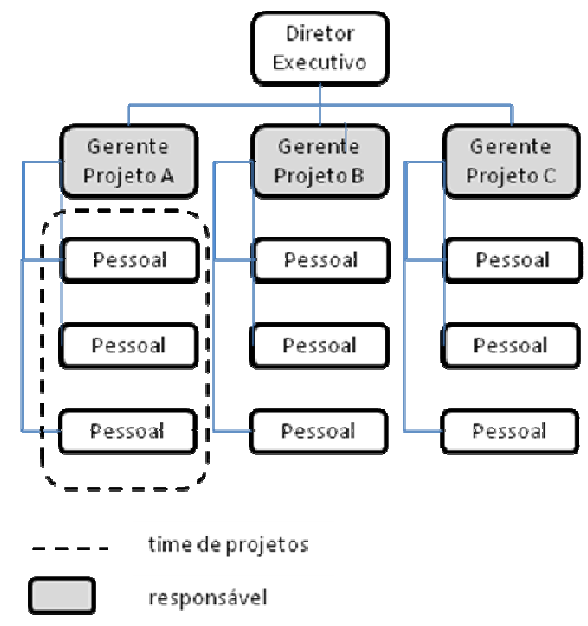

Estrutura Matricial:

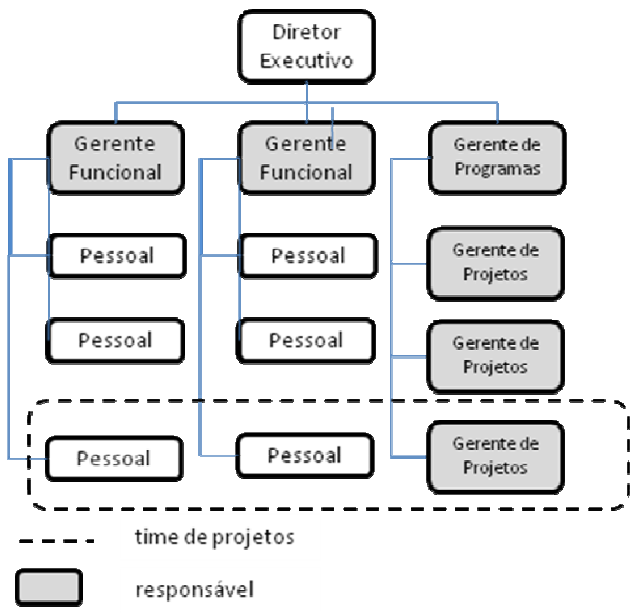

Fonte: Rozenfeld et al., (2006) 
Rozenfeld et al. (2006) apresentam duas formas clássicas de organização do PDP: a estrutura funcional e a estrutura autônoma por projeto. Na estrutura funcional, a ligação entre os indivíduos acontece primeiro entre aqueles que realizam funções similares. Na estrutura por projeto, essa ligação acontece preferencialmente entre aqueles que estão trabalhando em um mesmo projeto.

$\mathrm{Na}$ estrutura matricial, os indivíduos estão ligados a outros tanto por meio de suas áreas funcionais quanto por meio de um ou mais projetos. Neste contexto, o indivíduo normalmente tem dois superiores hierárquicos: um da organização funcional e outro referente ao projeto. Na prática, este compartimento fica difícil, em razão de questões de orçamento, avaliação de desempenho, entre outras questões. Clark e Fujimoto (1991) nomearam duas variações da estrutura matricial, conhecidas por "estrutura de projeto peso pesado" e "estrutura de projeto peso leve".

Quadro 4 - Características dos tipos de arranjos organizacionais

\begin{tabular}{|c|c|c|c|c|}
\hline Tipos de organização & \multirow[t]{2}{*}{ Funcional } & \multicolumn{2}{|c|}{ Matricial } & \multirow[t]{2}{*}{ Por projeto } \\
\hline Características & & Peso Leve & Peso Pesado & \\
\hline \multicolumn{5}{|c|}{ PERSPECTIVA DE LIDERANÇA } \\
\hline Autoridade do gerente de projeto & $\begin{array}{l}\text { Pouca ou } \\
\text { nenhuma }\end{array}$ & baixa & forte & forte \\
\hline Alocação do gerente de projeto & Tempo parcial & Tempo parcial & Tempo integral & Tempo integral \\
\hline $\begin{array}{l}\text { Principais funções desempenhadas } \\
\text { pelo gerente de projeto }\end{array}$ & Técnicas & $\begin{array}{c}\text { Técnicas } \\
\text { Comunicação }\end{array}$ & $\begin{array}{c}\text { Técnicas } \\
\text { Gerenciais } \\
\text { Negociação } \\
\text { Comunicação } \\
\end{array}$ & $\begin{array}{c}\text { Técnicas } \\
\text { Gerenciais } \\
\text { Negociação } \\
\text { Comunicação } \\
\end{array}$ \\
\hline $\begin{array}{l}\text { Responsabilidade pela integração } \\
\text { entre áreas funcionais }\end{array}$ & $\begin{array}{c}\text { Gerentes } \\
\text { funcionais }\end{array}$ & $\begin{array}{c}\text { Gerentes peso } \\
\text { leve }\end{array}$ & $\begin{array}{l}\text { Gerentes peso } \\
\text { pesado }\end{array}$ & $\begin{array}{l}\text { Gerentes de } \\
\text { projeto }\end{array}$ \\
\hline $\begin{array}{l}\text { Controle sobre o projeto de } \\
\text { desenvolvimento }\end{array}$ & $\begin{array}{l}\text { Compartilhada } \\
\text { entre o líder e os } \\
\text { gerentes } \\
\text { funcionais }\end{array}$ & $\begin{array}{l}\text { Compartilhada } \\
\text { entre o líder e os } \\
\text { gerentes } \\
\text { funcionais }\end{array}$ & $\begin{array}{c}\text { Total pelo gerente } \\
\text { de projetos }\end{array}$ & $\begin{array}{c}\text { Total pelo gerente } \\
\text { de projetos }\end{array}$ \\
\hline \multicolumn{5}{|c|}{$\begin{array}{ll}\text { PERSPECTIVA DO GRUPO } \\
\end{array}$} \\
\hline $\begin{array}{c}\text { Participação de pessoal de outros } \\
\text { departamentos funcionais alocados } \\
\text { ao projeto }\end{array}$ & Limitada & Limitada & Extensa & Extensa \\
\hline $\begin{array}{l}\text { Comunicação entre gerente de } \\
\text { projeto e os membros da equipe }\end{array}$ & Indireta & Direta e Indireta & Direta & Direta \\
\hline \multicolumn{5}{|c|}{$\begin{array}{l}\text { PERSPECTIVA DA APRENDIZAGEM } \\
\end{array}$} \\
\hline $\begin{array}{c}\text { Aprensizagem sistêmica (sobre o } \\
\text { projeto com um todo) }\end{array}$ & Baixa & moderada & Grande & Grande \\
\hline Criatividade & Focada na área & Focada na área & Mais sistêmica & Mais sistêmica \\
\hline
\end{tabular}

Fonte: Rozenfeld et al. ( 2006) 
Em uma estrutura de projeto peso pesado predomina a ligação baseada no projeto. O gerente do projeto, conhecido por "gerente peso pesado", tem completa autonomia e autoridade no orçamento e na avaliação do desempenho dos membros do seu time e, normalmente, toma a maioria das decisões sobre a alocação de recursos do projeto.

A estrutura de projeto peso leve apresenta ligações organizacionais mais fortemente baseadas na função que no contexto do projeto. Neste caso, o gerente do projeto atua como um coordenador ou administrador, não tendo autoridade nem controle sobre os indivíduos, sobre o orçamento do projeto. Estes recursos normalmente são controlados pelos gerentes funcionais.

O quadro 4 apresenta algumas características das formas de organização de times de projeto (funcional, matricial e por projeto), sob perspectiva da liderança, do grupo e de aprendizagem. Podemos observar que a aprendizagem em organizações por projeto ou matricial tipo peso pesado tende a ser maior que no tipo funcional, pois o time permanece mais focado no projeto.

Segundo Clark e Fujimoto (1991), existem algumas habilidades e comportamentos que caracterizam os gerentes peso pesado. São elas:

- Coordenação de responsabilidades em áreas abrangentes, incluindo produção, vendas e engenharia;

- Coordenação de responsabilidades por todo o período de projeto, do conceito ao mercado;

- Responsabilidade pelo conceito e patrocínio, bem como coordenação cross-funcional;

- Responsabilidade por especificações, objetivos de custo, layout e maior parte dos componentes;

- Responsabilidade por assegurar que o conceito do produto está cuidadosamente traduzido em detalhes técnicos do veículo; 
- $\quad$ Comunicação frequente e direta com projetistas e engenheiros do nível operacional, bem como através de conexões;

- $\quad$ Contato direto com clientes;

- $\quad$ Habilidades de comunicação com línguas e culturas diferentes;

- $\quad$ Talento em gerenciar conflitos;

- Imaginação de mercado e a habilidade de prever futuras expectativas dos clientes;

- Circulação entre as pessoas de projeto e grande capacidade de advogar pelo conceito do produto, focando menos a produção de documentação e realização de reuniões formais.

Os gerentes peso-pesado se comportam diferentemente dos tradicionais peso-leve por ter mais influência.

\subsubsection{Fluxo da informação no processo de desenvolvimento de produto}

Conforme visto na introdução deste trabalho, um dos fatores importantes a serem abordados é o fluxo de informação ao longo do PDP. A importância da comunicação neste processo já vem sendo estudada pelos principais autores que abordam o desenvolvimento de novos produtos (DNP).

Segundo Rozenfeld et al. (2006), o gerenciamento do fluxo de informações é importante no PDP, no qual existem entrada e saída de informações e a interação de diversas fontes de informações e áreas funcionais da empresa, fornecedores e clientes.

Durante o processo de desenvolvimento, informações são elaboradas, selecionadas, armazenadas, combinadas, decompostas e transformadas através de vários meios, 
incluindo o cérebro humano, papéis, memória de computador, software e materiais físicos. (CLARK; FUJIMOTO, 1991)

O desenvolvimento de produto envolve muitas atividades a serem executadas por diversos profissionais de diferentes áreas da empresa, como marketing, pesquisa \& desenvolvimento, engenharia de produto, suprimentos, manufatura e distribuição cada um vendo o produto por uma perspectiva diferente, mas complementar. Isso exige uma integração entre os diversos departamentos (ROZENFELD et al., 2006).

O ponto-chave para Clark e Fujimoto (1991) está na comunicação com os clientes. Este deve ser o objetivo principal. O desenvolvimento do produto cria valor quando leva mensagens da produção, que personaliza em produtos, e o departamento de marketing leva aos clientes que interpretam e geram experiências de satisfação ou insatisfação. (CLARK; FUJIMOTO, 1991).

Para Clark e Fujimoto (1991), um desenvolvimento de produto efetivo deve ter a habilidade de desenhar produtos e criar uma experiência positiva. Para isso, é necessário explorar a percepção, os desejos e expectativas do cliente.

Figura 6: Processos relacionados com o desenvolvimento de produtos

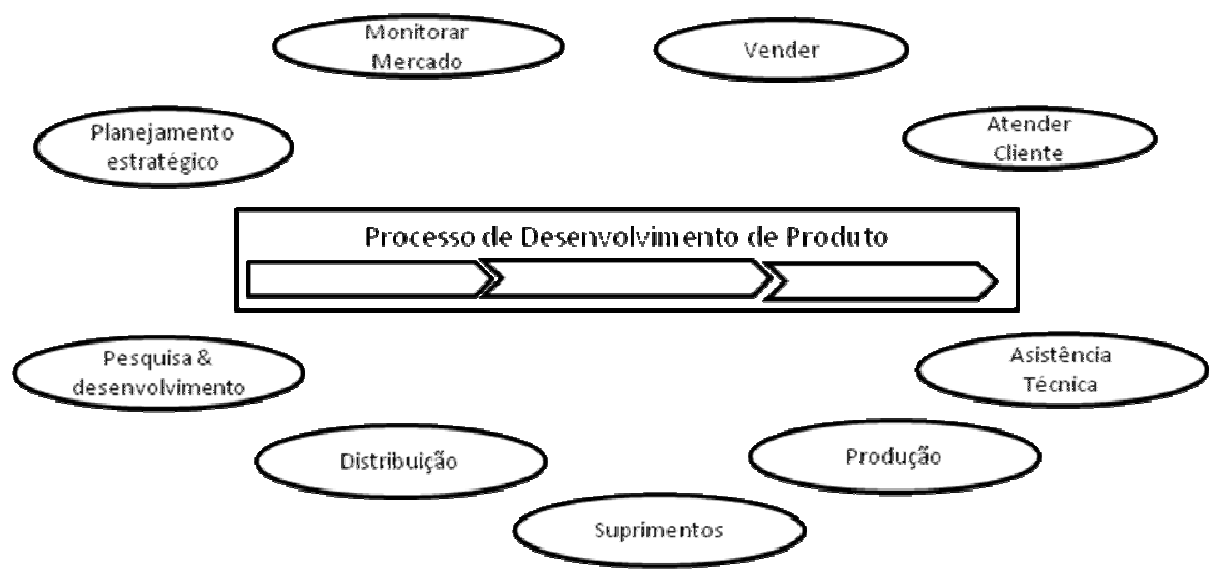

Fonte: Rozenfeld et al. (2006)

De fato, o processo de desenvolvimento de produtos situa-se na interface entre a empresa e o mercado, devendo identificar e até mesmo se antecipar às 
necessidades do mercado e propor soluções que atendam a tais necessidades (ROZENFELD et al., 2006).

Rozenfeld et al. (2006) apresentam alguns processos relacionados com 0 desenvolvimento de produtos.

Clark e Fujimoto (1991) propõem um ciclo no qual ocorre uma completa tradução de informações de produto dos clientes para engenheiros, produção, vendas, retornando aos clientes.

Figura 7 - Ciclo de desenvolvimento de produto

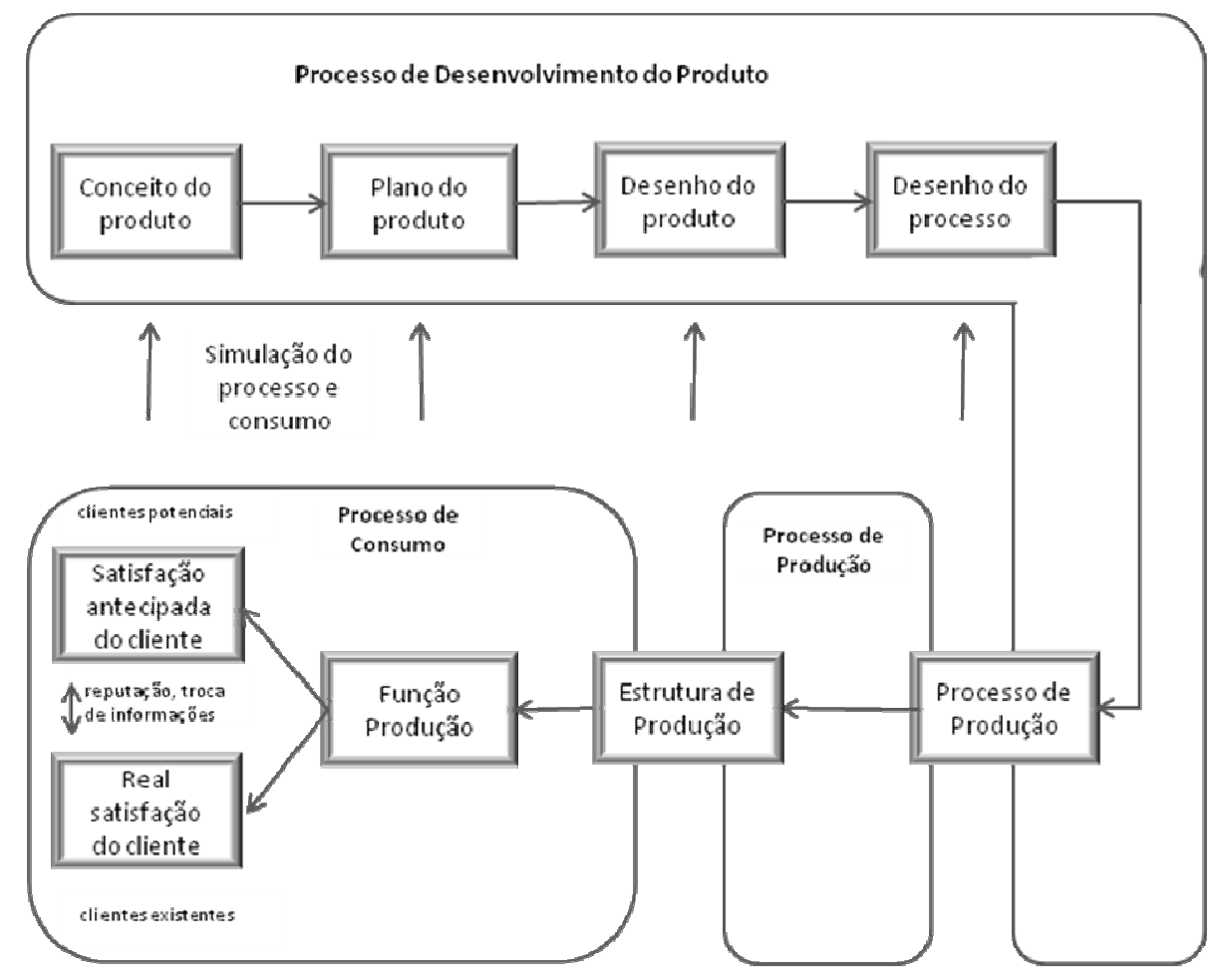

Fonte: adaptado de Clark e Fujimoto, 1991

O fluxo de informações apresenta especial importância no desenvolvimento de produtos quando existe não somente interação entre departamentos, mas também entre empresas e quando existe uma relação de cooperação de desenvolvimento e, portanto, responsabilidades compartilhadas. Este tipo de relação é comum na cadeia automotiva. 


\subsection{Cadeia automotiva e o desenvolvimento colaborativo}

\subsubsection{Cadeia de fornecimento automotiva}

Este trabalho irá abordar alguns aspectos das relações entre montadora e fornecedores no processo de desenvolvimento de produto. Serão apresentados aqui alguns aspectos da estrutura de fornecimento desta indústria, para que o leitor possa compreender melhor as formas de ação comuns neste meio.

Salerno et al. (2003) apresenta um modelo simplificado da cadeia de suprimentos automotiva demonstrado na figura 8.

Figura 8: Cadeia de suprimentos da indústria automotiva

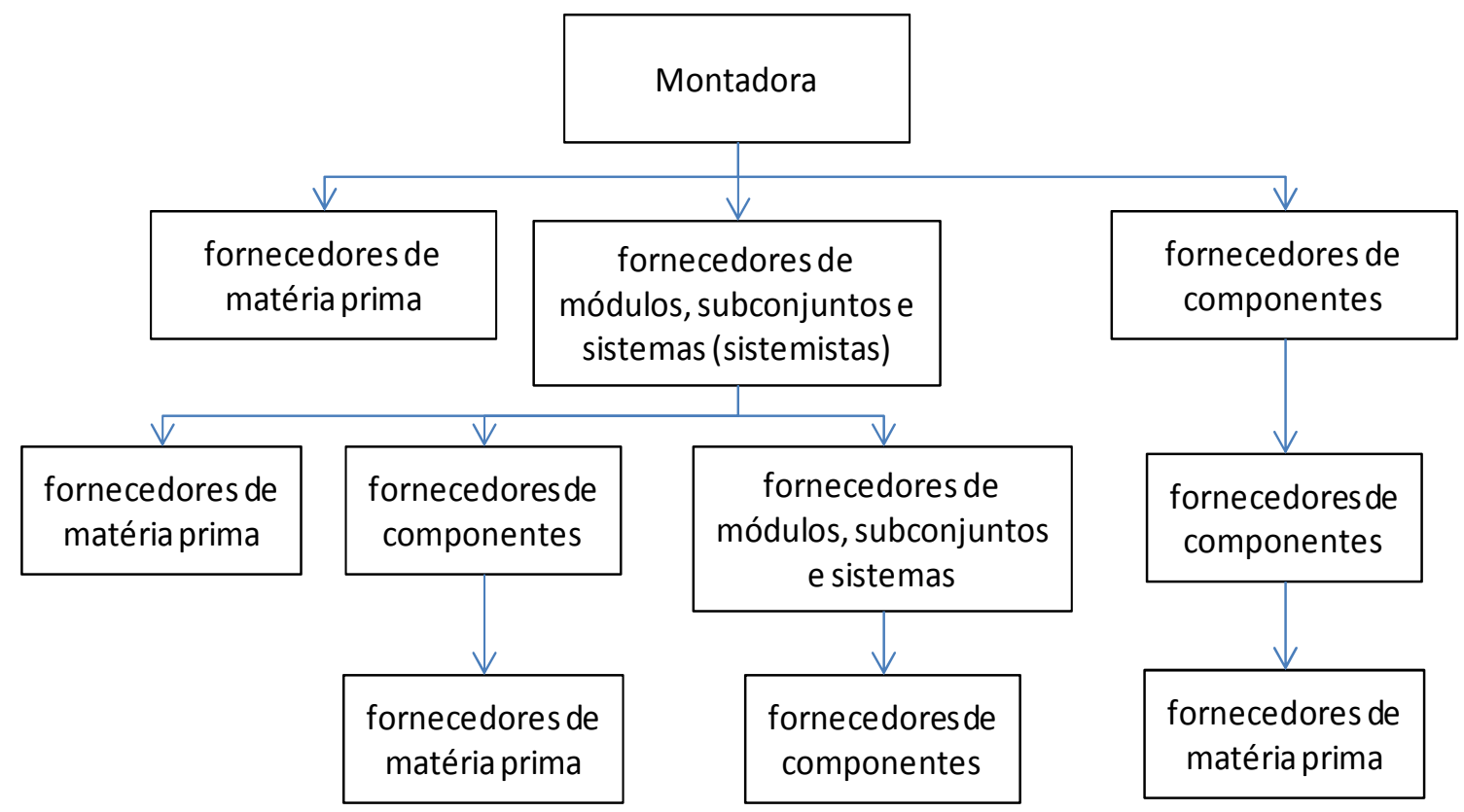

Fonte: Adaptado de Salerno et al. (2003)

Nesta cadeia, a montadora é considerada a indústria mais poderosa. Esta empresa é suprida pelos sistemistas, ou fornecedores de primeiro nível, e estes recebem suprimentos dos sub-fornecedores, ou fornecedores de segundo nível, e assim por diante (Salerno et al., 2003; Padovani, 2007). São consideradas empresas sistemistas aquelas responsáveis por entregar módulos, subconjuntos e/ou sistemas 
pré-montados diretamente nas fábricas das montadoras, geralmente instalando unidades no mesmo terreno destas, ou mesmo dentro do prédio da montadora. Esses arranjos são conhecidos como consórcio modular ou condomínio industrial (Salerno at al, 2003).

\subsubsection{Desenvolvimento colaborativo de produto}

A importância do desenvolvimento colaborativo de novos produtos (DCNP) foi abordada por Womack et al. (1997). Eles propõem que o DCNP permite a melhoria do custo do produto, a redução do custo e do tempo de desenvolvimento, a minimização do tempo de fabricação e a melhoria do desempenho do produto, devido à intervenção dos agentes envolvidos no processo de desenvolvimento. $O$ envolvimento dos fornecedores desde a fase de concepção dos produtos passou a ser de primordial importância na implementação de novos produtos/sistemas.

Quadro 5 - Papéis dos fornecedores

\begin{tabular}{|l|l|l|l|l|}
\hline \multirow{2}{*}{ INDICADORES DE DCNP } & Estágios de desenvolvimento dos relacionamentos inter-empresariais \\
\cline { 2 - 5 } & Contratual & Envolvimento & Maturidade & Parceria \\
\hline 1. Responsabilidade do projeto & cliente & conjunto & fornecedor & fornecedor \\
\hline 2. Complexidade do produto & $\begin{array}{l}\text { Componentes } \\
\text { simples }\end{array}$ & $\begin{array}{l}\text { Subconjuntos } \\
\text { simples }\end{array}$ & $\begin{array}{l}\text { Subconjuntos } \\
\text { complexa }\end{array}$ & Subsistema \\
\hline 3. Especificações fornecidas & Projeto completo & $\begin{array}{l}\text { Especificações } \\
\text { detalhadas }\end{array}$ & $\begin{array}{l}\text { Especificações } \\
\text { críticas }\end{array}$ & Conceito \\
\hline $\begin{array}{l}\text { 4. Influência do fornecedor na } \\
\text { Especificações }\end{array}$ & Nenhuma & Algumas & Negociadas & Colaboração \\
\hline 5. Estágio em que o fornecedor se envolve & Protótipo & Pós-conceito & Conceito & Pre-conceito \\
\hline 6. Responsabilidade do teste do componente & Menor & Moderada & Amplas & Completa \\
\hline 7. Capacidade tecnológica do fornecedor & Baixa & Média & Amplas & Autônomo \\
\hline
\end{tabular}

Fonte: Kamath e Liker (1994) apud Moreira (2005)

Dyer (1996) demonstrou que a qualidade, o tempo de desenvolvimento de novos produtos, os custos de armazenagem e a rentabilidade de ambos os parceiros, 0 
fornecedor e o cliente eram afetados pela forma como as empresas se relacionavam.

Kamath e Liker (1994) apud Moreira (2005) abordaram o relacionamento interempresarial partindo da perspectiva dos fornecedores. Apresentam os diferentes papéis dos fornecedores no DCNP ao longo de quatro estágios de maturidade de relacionamentos inter-empresariais.

Segundo Clark e Fujimoto (1991), o fornecedor pode participar do design e desenvolvimento de diferentes formas. São apresentados aqui três padrões:

- $\quad$ A peça é de propriedade de fornecedor;

- Peça black box;

- $\quad$ Peças controladas - por funcional ou forma.

Peça de propriedade do fornecedor: tipicamente peças de catálogo. São desenvolvidas pelo fornecedor desde o conceito até a venda. A mesma peça pode ser utilizada em diversos carros. Uma das vantagens está na economia de escala, a outra pode ser a confiabilidade do produto já testado. Uma desvantagem está no baixo controle do cliente sobre a engenharia da peça. Exemplos: elementos de fixação como presilhas, parafusos, conectores e lâmpadas automotivas.

Pecas black box: a montadora fornece os requisitos de custo, performance, forma e detalhes de interface com informações baseadas no planejamento do veículo. Pertencem a esta categoria peças funcionais, sistemas e sub-sistemas.

O conceito black box permite às montadoras aproveitarem o conhecimento e força de trabalho do fornecedor, enquanto mantêm o controle sobre o desenho básico e a integridade do veículo. A consequência do uso do conhecimento do fornecedor pode ser uma melhor qualidade e menor custo. O conhecimento do fornecedor se torna um fator crítico de competitividade. Neste caso, ter uma estrutura de protótipo e de produção facilita a troca de conhecimento entre os dois estágios, permitindo prevenir futuros problemas. 
O black box, porém, não está livre de riscos. Por exemplo, montadores podem ficar com conhecimento de engenharia defasado, o que, a longo prazo, pode gerar vulnerabilidade e comprometer o poder de negociação.

Um gerenciamento efetivo para este sistema requer cuidados. As montadoras devem estabelecer relações de longo prazo com fornecedores. Devem, também, balancear a necessidade de reter tecnologias e controlar a engenharia do produto, com a necessidade de adquirir novas tecnologias, adquiridas através dos fornecedores e dominadas por eles.

Relações duradouras requerem contratos de longo prazo, com a formação de parcerias, que são formas de relacionamento em que maior maturidade pode ser obtida (Kamath e Liker , 1994 apud Moreira, 2005). Para Clark e Fujimoto (1991), o efetivo desenvolvimento do fornecedor e gerenciamento de sistemas de peças black box é realizado através de contratos e organizações formais.

Peças detalhadamente controladas: os desenhos são realizados pelo cliente, que mantém todo o controle de engenharia básica. Algumas montadoras também realizam o processo de engenharia, constroem as ferramentas e equipamentos e os emprestam aos fornecedores.

As peças detalhadamente controladas são adequadas quando a montadora quer preservar o conhecimento de engenharia e o poder de negociação com fornecedores.

\subsubsection{Gestão do relacionamento com fornecedores}

A gestão no relacionamento entre clientes e fornecedores influencia não somente o custo direto do produto, mas diversas outras questões, como aspectos relacionados ao processo de desenvolvimento do produto.

Marinho (2001) aborda a seleção de fornecedores como um fator importante e propõe alguns critérios para esta escolha, que extrapolam a questão de preços. São eles: 
- Posição financeira;

- Gestão de pessoas: habilidades, treinamento e histórico de relações industriais;

- Conscientização comercial;

- Produtividade;

- Abordagem de gestão da qualidade;

- Foco em atividades de melhoria contínua.

Marinho (2001) aponta três estratégias básicas de aquisição, que refletem o estilo de relacionamento entre as empresas: tradicional, contratual e parceria. Estratégias intermediárias também são possíveis.

A estratégia de aquisição que ainda pode ser considerada a mais utilizada pelas empresas é a que enfatiza o menor preço. Tal estratégia, chamada tradicional, frequentemente leva o relacionamento entre o comprador e o fornecedor a uma situação de confronto, na qual ambos se consideram adversários, predominando o antagonismo e conflito nas relações.

O fornecedor é visto com desconfiança. São enfatizadas as ofertas de preços baixos e cada uma das partes envolvidas pressiona a fim de obter vantagens imediatas, mesmo que isso resulte na impossibilidade de negócios futuros. Neste tipo de relação, inevitavelmente uma parte ganha e a outra perde. Este é o chamado de jogo ganha-perde.

As empresas que adotam este tipo de política consideram seus fornecedores como externos a seu processo de negócio, como servidores que devem atender aos requisitos especificados.

A estratégia contratual pode ser considerada uma evolução, pois é baseada em um acordo de fornecimento, assinado por ambas as partes após exaustivas negociações. O objetivo comum, neste caso, é o atendimento às clausulas contratuais. 
Caminhando no sentido de aprimoramento das relações com fornecedores, está emergindo um novo paradigma de aquisição, o regime de parceria. Este é um relacionamento planejado e contínuo, baseado na confiança mútua, no planejamento conjunto, de assistência e visitas mútuas.

Este enfoque de parcerias baseia-se não mais no menor preço, mas no menor custo de aquisição. O custo total dos produtos comprados é composto pelo preço de compra adicionado aos custos de refugos gerados, de retrabalhos, de atrasos, de falhas em campo, assistência técnica, de atendimento a reclamações e de outras consequências da baixa qualidade dos produtos ou serviços adquiridos.

Johnston e Clark (2002) abordam outro fator fundamental para o alinhamento de objetivos das empresas clientes e fornecedoras, o estabelecimento de um contrato. O contrato de fornecimento deve ser desenvolvido de acordo com as necessidades e deve incluir:

- Concordância sobre as principais dimensões do desempenho, como tempo, disponibilidade, exatidão das respostas, etc. Isso permite ao cliente e ao fornecedor entenderem o que é importante no serviço, sob ambos os pontos de vista.

- Concordância sobre como cada dimensão acima será mensurada. A discussão e o acordo sobre as medidas a serem utilizadas reduzem a probabilidade de desentendimentos posteriores sobre o desempenho.

- Fixação de metas em cada dimensão. É possível que os padrões estabelecidos por uma parte estejam além das necessidades da outra. Clareza e concordância sobre o que é necessário e possível devem levar a um resultado viável e atingível e, de fato, de baixo custo.

- Definição da responsabilidade por mensurar cada dimensão. Diferentemente de um contrato tradicional, a responsabilidade pela mensuração do desempenho pode ser do fornecedor ou do cliente, mas tal informação está disponível para ambas as partes.

Já Laming (1996) apud Johnsen e Ford (2005) aborda mais de um nível de controle feito pelo cliente sobre a cadeia de fornecimento. Segundo ele, o cliente pode 
influenciar fornecedores de nível secundário, ou outros ainda mais "distantes”, por meio de duas estratégias: cascata ou intervenção.

A cascata acontece quando empresas impõem, por exemplo, políticas ou requisitos de performance aos fornecedores intermediários, criando a expectativa de que estes repassem para os sub-fornecedores (Lamming, 1996; Rich and Hines, 1998; Tilson, 2001 apud Johnsen e Ford, 2005)

A estratégia de cascata possibilita às empresas uma maneira de gerenciar a cadeia de fornecimento delegando ao fornecedor primário a responsabilidade de replicar os requisitos aos fornecedores secundários. A estratégia de intervenção é descrita de maneira similar à de cascatear (Lamming, 1996), mas impõe ao cliente estar diretamente envolvido nas atividades do sub-fornecedor e então tentar converter a relação indireta em relação direta. Lamming (1996) sugere ainda que a prática de controle ocorre porque o cliente não confia nas iniciativas do fornecedor.

Figura 9 - Controles exercidos na cadeia de fornecimento
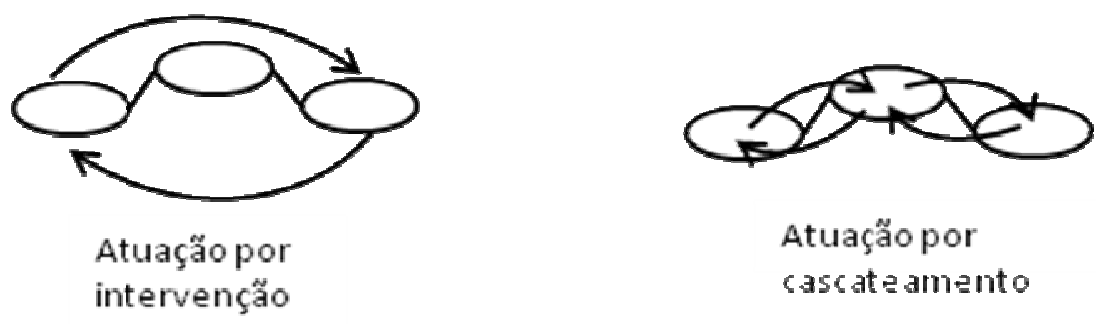

Atuação por

cascateamento

Fonte: adaptado de Johnsen e Ford (2005)

Tanto a estratégia de cascata como a intervenção supõem que o cliente possua posição de conhecimento operacional superior à do fornecedor (Lamming, 1996). Fundamentalmente, o cliente controla o fornecedor através de compras ou da cadeia de fornecimento. A fonte de poder está também relacionada à maior disponibilidade de informação e conhecimento ou a altos níveis de dependência do fornecedor como descrito na teoria de troca social e teoria do recurso dependente (Johnsen e Ford, 2005). 
O exercício de controle através de alta dependência do fornecedor pode ser prejudicial se o fornecedor perder sua capacidade de inovar, ou se for prejudicado nas relações com o cliente.

Fujimoto (2001) faz uma análise sobre o relacionamento com fornecedores como "o gerenciamento de recursos informais" e define três dimensões para o estabelecimento deste gerenciamento: participação, competição e transação.

A participação pode ser entendida como a linha que limita onde está o poder de decisão sobre as ações relacionadas à produção e ao desenvolvimento de produto. A participação está diretamente relacionada à divisão de responsabilidade entre cliente e fornecedor. Esta relação pode ocorrer em diversos estágios do sistema de manufatura, incluindo atividades de produção, ferramentas, equipamentos, desenho de processos, desenho de produto.

A competição entre fornecedores está relacionada às oportunidades de transação entre empresas. Quando a empresa compradora seleciona mais de um fornecedor potencial para uma oportunidade de transação, resulta uma competição entre os fornecedores. O comprador pode nomear um fornecedor para cada oportunidade de transação. Tal seleção por estrutura competitiva pode afetar padrões de comportamentos, estrutura organizacional, capacidade e performance de ambos, fornecedores e montadoras.

A transação está relacionada aos detalhes do relacionamento entre as empresas, ou como será realizada a interface. Quando os limites para a realização da compra estão estabelecidos em uma rede de recursos produtivos, os detalhes para cada transação individual devem ser desenhados e implementados. Como cada transação consiste em um pacote de fluxo de informações definido na interface entre as empresas em termos de conteúdo, tempo, mídia, e outros, para cada transação as empresas podem escolher entre contratos de longo prazo e curto prazo, contatos frequentes ou não, comunicação formal ou informal, entre outros.

\subsection{Fatores de sucesso em projetos}


Este capítulo irá abordar os fatores de sucesso em projetos já estudados e disponíveis em bibliografia. O propósito deste estudo é identificar questões importantes relacionadas ao sucesso em projetos, com a finalidade de auxiliar a análise dos estudos de casos e a identificação de questões que contribuam positivamente e negativamente para o desenvolvimento dos projetos.

Rubin e Seeling (1967) apud Torr e Ogunlana (2007) foram os primeiros a introduzir o conceito de fatores de sucesso em projetos, e Rockart (1982) apud Torr e Ogunlana (2007), o primeiro a utilizar a terminologia "fatores críticos de sucesso". Kerzner (1987) declarou que fatores críticos de sucesso podem ser aplicados a empresas de quaisquer ramos.

Segundo De Wit (1988), "sucesso no projeto" refere-se aos objetivos do projeto, enquanto "sucesso no gerenciamento" de projeto refere-se aos indicadores de custo, qualidade e tempo. Os "fatores de sucesso" compõem o sistema de gerenciamento que será avaliado a fim de se alcançar sucesso no projeto ou negócio.

Fatores críticos de sucesso são fatores que devem existir em uma organização para criar um ambiente onde os projetos podem ser gerenciados com excelência e com uma base consciente (KERZNER, 1987).

Para Kerzner (1987), são seis os fatores críticos para excelência em gestão de projetos: a) entendimento corporativo de gestão de projetos; b) comprometimento executivo com gestão do projeto; c) adaptabilidade organizacional; d) critério de seleção do gerente de projetos; e) estilo de liderança do gerente de projetos; f) comprometimento com o planejamento e controle.

Benassi et al. (1996) apud Westerveld (2003) iniciaram o estudo dos fatores críticos de sucesso e indicaram que: a) fatores de sucesso devem ser distinguidos dos fatores críticos de sucesso; b) fatores de sucesso sob controle do gerente de projetos devem ser distinguidos de fatores externos, fora do controle do gerente de projetos.

Pinto e Slevin (1983) realizaram uma pesquisa de campo em projeto de larga escala e identificaram 14 fatores críticos de sucesso na implementação de projetos. Os 10 primeiros fatores críticos são de controle do time de projeto, enquanto os quatro seguintes não. Os 10 primeiros são: a) missão do projeto; b) suporte gerencial; c) 
planejamento; d) cliente consultor; e) questões de administração de pessoal; f) tarefas técnicas; g) aceite do cliente; h) monitoramento; i) comunicações; j) gerência conciliadora.

Butcher e Jeffrey (2007) fizeram um estudo a partir de pesquisas colaborativas entre instituições acadêmicas e empresas industriais e mostraram que características da supervisão, do gerente do projeto e características relativas à comunicação estão correlacionadas com a percepção do sucesso daqueles que estão envolvidos no projeto.

Um levantamento realizado por Fortune e White (2006) aponta os principais fatores críticos de sucesso indicados pelos estudiosos desta área nos período de 1989 a 2005. São eles: 1) suporte da gerência sênior; 2) objetivos claros e realistas; 3) plano forte e detalhado mantido atualizado; 4) boa comunicação/ retroalimentação; 5) envolvimento / participação do cliente; 6) time com habilidades/ qualificação adequada/ quadro de pessoal suficiente; 7) gerenciamento de mudanças efetivo; 8) gerente de projetos competente; 9) base de projeto sólida; 10) recursos suficientes e bem alocados; 11) boa liderança; 12) experiência/ familiaridade com a tecnologia; 13) cronograma realista; 14) riscos avaliados/ endereçados/ gerenciados; 15) patrocinador do projeto; 16) controle/ monitoramento efetivo; 17) verba adequada; 18) adaptação da estrutura/ cultura organizacional; 19) boa performance dos fornecedores/ contratados/ consultores; 20) plano de encerramento/ revisão/ aceitação de possíveis falhas; 21) disponibilização de treinamento; 22) estabilidade política, 23) escolhas corretas/ experiência passada em metodologia/ ferramentas de gerenciamento de projetos; 24) influências do ambiente; 25) aprendizagem com experiências passadas; 26) tamanho do projeto/ nível de complexidade/ número de pessoas envolvidas/ duração; 27) valorização de diferentes pontos de vista.

Entre os 27 fatores levantados por Fortune e White (2006), os mais citados nos artigos pesquisados dentro do período de 1989 a 2005 são: a) a importância de o projeto ter suporte da gerência sênior; b) objetivos claros e realistas; c) ter um plano de trabalho eficiente.

A pesquisa realizada por Fortune e White (2006) mostra que existe uma limitação na concordância sobre os fatores críticos de sucesso de projetos entre os diversos 
autores que pesquisaram esta área.

Segundo Urban e Hauser (1993) apud Moreira (2005), o desenvolvimento de novos produtos está associado ao bom desempenho empresarial. Os autores identificaram vários fatores importantes relacionados ao desenvolvimento e lançamento de novos produtos.

Fatores de sucesso: respostas às necessidades dos consumidores; elevado valor agregado para os clientes; produtos inovadores, superioridade técnica; sistema de apoio à decisão de análise; ambiente competitivo favorável; adequação da organização à indústria; comunicação inter-funcional; compromisso da gestão de topo; processo disciplinado de desenvolvimento de novos produtos; departamento de desenvolvimento dinâmico; time-to-market reduzido; aversão a riscos desnecessários; estratégia global; orientação para a qualidade e para a satisfação do consumidor. (Urban e Hauser, 1993 in Moreira, 2005)

Motivos de insucesso: mercado reduzido; falhas de previsão; produtos pouco inovadores; fraco retorno do investimento; problemas organizacionais; falhas na coordenação inter-funcional; mudanças nos gostos dos consumidores; fraco posicionamento estratégico; inadequado tratamento do canal distribuidor; mutações tecnológicas quando do desenvolvimento; processo indisciplinado de desenvolvimento de novos produtos; mudanças no ambiente competitivo; fraco serviço pós-venda (Urban e Hauser, 1993 in Moreira, 2005).

Segundo Pinto e Slevin (1987), o sucesso do projeto é alcançado quando quatro critérios são atendidos: tempo, custo, eficácia e satisfação do cliente.

O sistema de manufatura da empresa, incluindo a produção, o desenvolvimento do produto e o sub-sistema fornecedor pode ser completamente entendido quando reinterpretado como um sistema que cria, armazena e transmite informação de projeto com valor (Fujimoto, 2001).

\subsection{Síntese da revisão bibliográfica}


Considerando a complexidade da indústria automotiva, somada à complexidade existente em qualquer fluxo do processo de desenvolvimento e da interação entre empresas e departamentos, fica claro que existe a necessidade de organizar o processo de desenvolvimento.

A organização do processo de desenvolvimento de produto implica não somente o estabelecimento de fases e atividades do processo, conforme proposto por Clark e Fujimoto (1991), mas também o diagnóstico de algumas características fundamentais que envolvem o projeto. Entre as definições do desenvolvimento aqui abordadas, estão:

- Grau de inovação no desenvolvimento - projetos radicais, próxima geração, incrementais, follow-source, pesquisa avançada (ROZENFELD et al., 2006);

- $\quad$ Estrutura do time de projeto e liderança a ela associada;

- Grau de envolvimento do fornecedor no desenvolvimento - peças controladas, black box ou propriedade do fornecedor (CLARK; FUJIMOTO, 1991);

- Estratégias básicas de aquisição, conforme proposto por Marinho (2001) tradicional, contratual e parceria;

- Grau de maturidade do envolvimento do fornecedor, proposto por Kamath e Liker (1994).

Outros aspectos importantes relacionados ao desenvolvimento também foram identificados em literatura, entre eles, a importância das fases iniciais do projeto, para custos e qualidade (VERGANTI, 1999).

Realizando uma análise comparativa entre as fases de desenvolvimento apresentadas na revisão bibliográfica, é possível observar que existem semelhanças nas fases de desenvolvimento propostas por Clark e Fujimomto, por Cooper (2008) e pelo APQP. O APQP contempla o planejamento, desenvolvimento do produto e processo propostos por Clark e Fujimoto (1991), e inclui as etapas de teste e validação propostas por Cooper (2008). 
Clark e Fujimoto (1991) e Kerzner (1987) propõem parâmetros de performance para avaliar o desempenho do projeto. Estas performances estão diretamente relacionadas à competitividade de longo prazo do produto. Entre elas, estão tempo, produtividade e qualidade do produto. O APQP pretende acompanhar a performance de tempo e qualidade ao longo de todo o processo, estabelecendo atividades a serem cumpridas em casa fase. Trata-se de uma metodologia focada na qualidade do produto. Este objetivo fica evidente com algumas atividades definidas, entre elas: estudos iniciais, validação de sistemas de medição, validações de materiais e dimensionais, aprovação de aparência, documentos de processo, entre outros. A produtividade apresenta um aspecto mais subjetivo no APQP, quando propõe que cada etapa concluída passe por um processo de reflexão e que, ao final, todo o processo seja avaliado, e que melhorias sejam buscadas.

Podemos perceber que o APQP não pretende administrar todos os aspectos que envolvem o PDP, mas sim monitorar o processo, de maneira a identificar aspectos que possam dificultar ou impossibilitar o cumprimento das disciplinas fundamentais para a finalização do desenvolvimento e validações de produto e processo. 


\section{MÉTODO E PROCEDIMENTOS DE PESQUISA}

Este capítulo apresenta o método de pesquisa e coleta de dados adotados nesta dissertação. São apresentadas, também, as questões de pesquisa, as justificativas para a escolha do método e o instrumento de coleta de dados.

\subsection{Método de pesquisa e coleta de dados}

Segundo Ghauri et al. (1995), o processo científico de pesquisa se inicia com a definição do problema que será estudado. A partir daí, os autores propõem um fluxo, no qual segue a representação do problema, desenho de pesquisa, medições, amostras, análise dos dados e recomendações. Os autores propõem, ainda, que o pesquisador responda a duas perguntas: qual é o problema? E como será resolvido?

Neste trabalho de pesquisa se busca identificar fatores relevantes que favoreçam ou desfavoreçam a gestão do processo de desenvolvimento do produto realizada através da metodologia APQP.

Nakano e Fleury (1996) analisam os métodos de pesquisa em engenharia de produção e sugerem dois grupos: método qualitativo e a quantitativo. Segundo os autores, os métodos qualitativos são interpretativos, analisando os aspectos ligados às pessoas que são objeto de pesquisa, à observação dos fatos do ponto de vista de alguém interno ao problema e à compreensão profunda do contexto da situação a ser estudada.

Segundo Gil (2007), o estudo de caso consiste no estudo profundo e exaustivo de um ou de poucos objetos, de maneira a permitir seu amplo e detalhado conhecimento. Entre os propósitos citados por ele para o desenvolvimento de um estudo de caso estão:

- Explorar situações da vida real cujos limites não estão claramente definidos; 
Descrever a situação do contexto em que está sendo feita determinada investigação;

- Explicar variáveis causais de determinado fenômeno em situações muito complexas que não possibilitam a utilização de levantamentos e experimentos.

No trabalho aqui apresentado, se faz necessário analisar, de maneira aprofundada, casos reais de desenvolvimento de produto, nos quais alguns limites de contorno são conhecidos, como o ambiente social e econômico, setor da indústria, tipo de produto desenvolvido, entre outros. Porém, muitos dos limites somente serão identificados ao longo do trabalho de pesquisa, como o tipo de relação que se estabelece entre as empresas, organização do trabalho, entre outros, de forma que estes fatores farão parte das análises que buscam compreensão dos fatos. Estas informações dificilmente poderiam ser adquiridas, por exemplo, por meio de um trabalho de levantamento, sendo mais adequado o estudo de caso.

Segundo Yin (1994), o estudo de caso é o delineamento mais adequado para a investigação na qual os limites entre o fenômeno e o contexto não são claramente percebidos.

Quadro 6 - Métodos de pesquisa e critérios de escolha

\begin{tabular}{|l|l|l|l|}
\hline Método de pesquisa & Questões Típicas & $\begin{array}{l}\text { Requer controle sobre o } \\
\text { comportamento dos } \\
\text { eventos? }\end{array}$ & $\begin{array}{l}\text { Focado em } \\
\text { contemporâneos? }\end{array}$ \\
\hline Pesquisa experimental & Como? Por quê? & Sim & Sim \\
\hline $\begin{array}{l}\text { Pesquisa de } \\
\text { levantamento }\end{array}$ & $\begin{array}{l}\text { Quem? O quê? Onde? } \\
\text { Quanto? }\end{array}$ & Não & Sim \\
\hline Análise de arquivos & $\begin{array}{l}\text { Quem? O quê? Onde? } \\
\text { Quanto? }\end{array}$ & Não & Sim/Não \\
\hline Pesquisa histórica & Como? Por quê? & Não & Não \\
\hline $\begin{array}{l}\text { Pesquisa qualitativa/ } \\
\text { estudo de caso }\end{array}$ & Como? Por quê? & Não & Sim \\
\hline
\end{tabular}

Fonte: Adaptado de Yin (1994)

Ainda segundo Yin (1994), a seleção do método depende do tipo de pesquisa proposta, do controle do pesquisador sobre o evento e do foco nos acontecimentos. O quadro 6 apresenta a relação entre os métodos de pesquisa e alguns critérios de escolha. 
A questão de pesquisa está associada a "como" e "porque" e está relacionada a fatos contemporâneos. Isso sugere a necessidade de uma pesquisa qualitativa / estudo de caso.

Segundo Gil (2007), com base nos objetivos, as pesquisas podem ser classificadas como:

- Exploratórias: têm como objetivo proporcionar maior familiaridade com o problema, a fim de torná-lo mais explícito ou a construir hipóteses. O objetivo principal é o aprimoramento de idéias ou a descoberta de intuições;

- Descritivas: têm como meta principal a descrição de características de determinada população ou fenômeno, ou então o estabelecimento de relações entre variáveis;

- Explicativas: busam, primordialmente, identificar fatores que determinem ou contribuam para a ocorrência de fenômenos. Explica o porquê das coisas.

Neste trabalho, a pesquisa pode ser classificada como exploratória, pois será necessário explorar os casos, buscar compreensão dos fatos, para então estabelecer os fatores que serão considerados significativos no processo de gestão do projeto feita com uso de metodologia APQP.

Para identificar estes fatores, alguns pressupostos são considerados. As empresas que serão pesquisadas devem utilizar a metodologia APQP para gerir e fazer interface entre montadora e fornecedor. O uso desta metodologia deve ser feito de forma interativa e poderão ser coletadas as informações de fatores significativos para qualquer uma das empresas, fornecedor ou cliente. Supõe-se, ainda, que existam fatores mais ou menos relevantes e que, de alguma maneira, possam ser identificadas consequências ou resultados da atuação positiva ou negativa destes fatores.

Segundo Eisenhardt (1989), a seleção do estudo de caso é um aspecto fundamental, pois a amostra confiável pode minimizar distorções de determinadas populações. 
Considerando que este trabalho deseja estudar o desenvolvimento de produtos, o qual se trata de um acontecimento complexo, optou-se por realizar dois estudos de caso, ambos selecionados por serem considerados eventos dentro do contexto desejado para esta pesquisa, como será descrito a seguir. Após o estudo dos dois casos mencionados, foi identificada a necessidade de uma análise específica em um grupo mais amplo, com a finalidade de avaliar se as conclusões sugeridas a partir dos dois primeiros casos seriam representativas para um grupo maior de projetos.

Segundo Voss et al. (2002), é possível utilizar diferentes casos, a partir da mesma empresa, para estudar diferentes questões, ou pesquisar a mesma questão, em variados contextos, na mesma empresa. Neste trabalho, todos os casos estudados ocorreram dentro da mesma montadora. Os dois casos explorados nos capítulos 4.1.1 e 4.1.2 ocorreram com o mesmo fornecedor, porém em projetos distintos. Os casos adicionais apresentados no capítulo 4.1.3 tratam de diversos fornecedores atuando em um mesmo projeto.

Segundo Eisenhardt (1989), os métodos de coleta de dados são também fundamentais para que as informações sejam substanciais.

Neste trabalho, foi possível utilizar os seguintes métodos de coleta: documentos, atas, registros de projeto e entrevistas. A utilização de métodos diferentes para realizar a coleta de informações, como documentos, entrevistas, bem como a obtenção de dados provindos das empresas cliente e fornecedora, contribui para que distorções sejam minimizadas (EISENHARDT, 1989; VOSS, 2002).

A partir da análise documental, é possível coletar dados mensuráveis como cronograma de projeto, fidelidade da execução do cronograma previsto com a realizada, ocorrência ou não das reuniões previstas, resultados das reuniões. As entrevistas são importantes para auxiliar a interpretação dos documentos e levantar informações de conhecimento dos participantes que não constam em documentos. A seleção dos diversos entrevistados fornece a oportunidade de verificar visões e abordagens diferentes. 


\subsection{Descrição dos casos e instrumentos de pesquisa}

Para o desenvolvimento do trabalho de pesquisa, o critério de seleção levou em consideração a existência de um projeto com integração entre fornecedor e montadora. Isso porque peças de propriedade do fornecedor (CLARK; FUJIMOTO, 1991) ou do tipo peças de prateleira requerem menor interação entre fornecedor e cliente, se tornando menos atrativas para o estudo em questão.

Analisando peças produzidas por meio de interações relevantes entre montadora e fornecedor, outro critério foi buscar um produto feito com alguma responsabilidade de engenharia do fornecedor, pois, neste caso, a interação se torna ainda mais necessária.

Analisando, por fim, a acessibilidade às empresas, documentos e entrevistas para desenvolver o trabalho, foram selecionados dois casos junto a um fornecedor de sistemas elétricos (conhecidos como "chicote"), com responsabilidade de desenvolvimento compartilhada entre montadora e fornecedor. Estes casos se mostraram particularmente interessantes, pois o sistema elétrico possui uma interação complexa com outros componentes do veículo, quais sejam, todas as partes que necessitam de carga elétrica. Esta interação ampla se torna interessante durante um processo de desenvolvimento, pois como os componentes estão interligados, mudanças, indefinições ou falhas no desenvolvimento de diversos itens têm consequências sobre o sistema elétrico, enriquecendo a oportunidade de estudos para este trabalho.

Para o primeiro caso da pesquisa, foi selecionado um projeto recente, desenvolvido entre 2008 e 2009. Este é um projeto importante para a montadora, pois visa o atendimento a uma nova regulamentação governamental, sem o qual a empresa não poderia mais comercializar o veículo. É um projeto promissor, também, por estar em fase de finalização e, por isso, proporcionar informações com facilidade. O segundo caso irá tratar de um trabalho em andamento. Este se apresenta interessante por se tratar de um projeto de grande porte (um veículo completamente novo), com responsabilidade de design compartilhada, entre a montadora e fornecedor, registrada em contrato. Por estar ainda em fase de engenharia, dispõe de 
informações desta fase mais acessíveis, em documentos e na memória dos entrevistados.

Desta forma, as amostras possibilitarão estudar casos de produtos e projetos diferentes. A diferença de complexidade dos dois casos selecionados poderá contribuir para identificar fatores em projetos de portes diversos e também para evitar distorções inerentes à realidade de um único projeto.

Fornecedor e montadora estão localizados no Estado de São Paulo. A montadora é americana e exige de seus fornecedores o uso de ferramentas e metodologias guiadas pelo ISO/TS 16949, que é um sistema de certificação que regulamenta diversas atividades, dentre elas o desenvolvimento de produto. O fornecedor provê sistemas elétricos e está entre os maiores de mundo, com 38 sites espalhados pelas Américas do Norte, Central e Sul, Europa e Ásia. Por se tratar de um fornecedor grande e com padrões de atuação em suas diversas plantas, esta empresa, além de atender aos requisitos e normas do cliente, precisa ainda atender a seus próprios requisitos e processos internos.

Ao longo do trabalho de pesquisa aqui realizado, foi identificada a necessidade de avaliar se as conclusões obtidas nos casos 1 e 2 poderiam ser consideradas representativas para um grupo maior de fornecedores. Para realização deste estudo, foi escolhido o projeto do novo veículo e, dentro deste projeto, foram selecionados os fornecedores considerados "críticos" pelo critério da própria montadora.

O trabalho aqui desenvolvido busca identificar fatores que influenciam a gestão do APQP. Desta forma, os documentos inseridos no contexto do APQP serão fundamentais para o estudo. Entre eles, estão: o formulário no qual é feito o relatório do APQP para a montadora; documentos utilizados para suportar informações contidas no APQP, como cronograma do projeto, cronograma de ferramental, cronograma de testes de validação, atas de reunião interna, além de outros documentos que possam estar relacionados ao processo de desenvolvimento, acompanhamento ou validação do produto. A partir destes documentos, espera-se encontrar questões relacionadas a sucessos ou insucessos no projeto, bem como fatores relacionados às ocorrências. 
Foram realizadas entrevistas com integrantes do time de projeto a partir de um questionário semi-estruturado, apresentado no apêndice $A$. Entre os entrevistados selecionados dentro do fornecedor, estão: gerente de projeto, coordenador do projeto, líder de projeto, engenheiro de produto e engenheiro de qualidade. Dentro da montadora, foram entrevistados engenheiro da qualidade e engenheiro de produto.

Os profissionais entrevistados trabalham nestes projetos com responsabilidades e atividades distintas, contribuindo para que a visão de cada um no processo seja particular.

$\mathrm{Na}$ empresa fornecedora, o gerente de projeto tem uma responsabilidade sobre o gerenciamento de prazos e coordenação do cronograma geral. Possui, portanto, uma visão mais ampla para gerenciar as atividades e negociar com o cliente, porém não detalhada em questões pontuais, como prazos específicos de determinadas atividades do processo. O coordenador de projeto tem a responsabilidade de coordenar as atividades dentro da planta de manufatura do fornecedor. Sua visão é mais limitada ao processo interno, mas precisa considerar os prazos da montadora. Este profissional precisa dominar detalhes das atividades e prazos internos, mas não possui acesso a negociações de prazos junto à montadora. O líder de projeto coordena os engenheiros de produto do fornecedor. Precisa ter conhecimento detalhado das atividades de desenvolvimento de projeto, alterações e necessidades da engenharia do cliente. Possui acesso a negociações de datas, com interface mais forte junto ao gerente de projeto, porém tem pouca influência sobre prazos junto à planta de manufatura do fornecedor. Os engenheiros de produto do fornecedor e da montadora atuam diretamente na execução das atividades de definição do produto e toda a burocracia que envolve este trabalho. $O$ engenheiro da qualidade que trabalha na manufatura do fornecedor é responsável, no final do processo, pela aprovação dos testes de validação de produto e do processo. Os engenheiros de produto e de qualidade da montadora são responsáveis pelo acompanhamento do APQP e pela validação final, sendo o engenheiro do produto mais focado na validação do produto e o engenheiro de qualidade mais focado no processo de manufatura do fornecedor. 
Sendo assim, por meio destes profissionais foi possível coletar visões diferentes. Os profissionais ligados à engenharia do produto possuem uma visão mais direcionada às questões e dificuldades de definição do produto. Os profissionais mais próximos da manufatura possuem uma visão mais direcionada à manufatura e menos à engenharia de produto e negociações com clientes. Os engenheiros da montadora possuem maior conhecimento das dificuldades internas e, portanto, são mais tolerates a elas. A composição destas visões forneceu a possibilidade de constituir a estrutura geral do processo, composta por diversas percepções do processo e dos problemas e tratativas possíveis a eles.

As entrevistas foram realizadas de forma presencial e algumas informações foram completadas via telefone ou e-mail. Uma visão geral dos entrevistados no projeto pode ser observada no quadro 7 .

As entrevistas presenciais são fundamentais para o entendimento de aspectos subjetivos, que estão inseridos no contexto do processo de desenvolvimento, mas não são facilmente interpretados. As questões remanescentes da pesquisa podem ser completadas por telefone ou por e-mail.

Foi utilizado questionário semi-estruturado (anexo ou apêndice A) para tornar possível a captação de informações adicionais ao previsto no questionário (VOSS, 2002). Desta forma, a pesquisa semi-estruturada permitiu acesso às informações previstas no questionário, mas também a questões não previamente consideradas.

Para a elaboração do questionário, foi considerada a revisão bibliográfica e, em especial, a síntese bibliográfica apresentada no capítulo 2.5. A partir desta, foram estabelecidos objetivos de busca e questões a serem abordadas em entrevistas e documentos. 
Quadro 7 - Síntese dos casos e dos levantamentos de campo realizados

\begin{tabular}{|c|c|c|c|c|c|c|}
\hline Caso do estudo & Tipo de produto & $\begin{array}{l}\text { Projeto da } \\
\text { montadora }\end{array}$ & $\begin{array}{l}\text { Características do projeto da } \\
\text { montadora }\end{array}$ & $\begin{array}{c}\text { Empresa } \\
\text { fornecedora }\end{array}$ & Numero de entrevistados & Aspectos analisados \\
\hline primeiro caso & Sistema elétrico & $\mathrm{X} 1$ & $\begin{array}{l}\text { Inclusão de um novo sistema com a } \\
\text { finalidade de agregar uma nova função ao } \\
\text { usuário final. } \\
\text { Projeto com finalidade de atendimento à } \\
\text { novas exigências governamentais. }\end{array}$ & A1 & $\begin{array}{l}7 \text { entrevistados entre: } \\
\text { - engenheiro de produto da montadora } \\
\text { - } 2 \text { engenheiros da qualidade da } \\
\text { montadora } \\
\text { - gerente de projeto do fornecedor } \\
\text { - coordenador do projeto na manufatura do } \\
\text { fornecedor } \\
\text { - líder do projeto na engenharia do } \\
\text { fornecedor } \\
\text { - engenheiro do produto do fornecedor }\end{array}$ & \multirow{2}{*}{$\begin{array}{l}\text { - Escopo do projeto } \\
\text { - Planilhas de APQP } \\
\text { - Dificuldades dos projetos } \\
\text { - Tipo de abordagem segundo Rozenfeld et al (2006) } \\
\text { - Aspectos relacionados à gestão de projetos segundo } \\
\text { Kerzner (1987) } \\
\text { - Estágio do desenvolvimento do relacionamento segundo } \\
\text { Kamath e Liker (1994) apud Moreira (2005) } \\
\text { - Forrecedores e o processo de engenharia segundo } \\
\text { Clarck e Fujimoto (1991) } \\
\text { - Arranjos organizacionais segundo Rozenfeld et al (2006) } \\
\end{array}$} \\
\hline segundo caso & Sistema elétrico & $\mathrm{x} 2$ & $\begin{array}{l}\text { Projeto de desenvolvimento de um novo } \\
\text { veículo para montagem no Brasil } \\
\text { Veículo já existente em outro país, mas } \\
\text { com necessidade de adaptação de } \\
\text { produtos e processos para a montagem } \\
\text { no Brasil }\end{array}$ & $\mathrm{A} 1$ & $\begin{array}{l}8 \text { entrevistados entre: } \\
\text { - } 2 \text { engenheiros de produto da montadora } \\
\text { - } 2 \text { engenheiros da qualidade da } \\
\text { montadora } \\
\text { - gerente de projeto do fornecedor } \\
\text { - coordenador do projeto na manufatura do } \\
\text { fornecedor } \\
\text { - líder do projeto na engenharia do } \\
\text { fornecedor } \\
\text { - engenheiro do produto do fornecedor }\end{array}$ & \\
\hline $\begin{array}{l}21 \text { fornecedores } \\
\text { críticos - } 204 \\
\text { produtos }\end{array}$ & $\begin{array}{l}\text { elétricos, carroceria e } \\
\text { motorização }\end{array}$ & $\mathrm{x} 2$ & $\begin{array}{l}\text { Projeto de desenvolvimento de um novo } \\
\text { veículo para montagem no Brasil } \\
\text { Veículo já existente em outro país, mas } \\
\text { com necessidade de adaptação de } \\
\text { produtos e processos para a montagem } \\
\text { no Brasil }\end{array}$ & $\begin{array}{l}21 \text { forencedores } \\
\text { críticos }\end{array}$ & $\begin{array}{l}\text { responsével pelo recolhimento de todos os } \\
\text { APQPs na montadora }\end{array}$ & conclusōes previamente identificadas nos casos 1 e 2 \\
\hline
\end{tabular}

Fonte: levantamento do autor 


\subsection{Método de coleta e análise dos documentos utilizados para o estudo}

Como foi apresentado anteriormente, o APQP se divide, basicamente, em cinco fases: planejamento, desenho e desenvolvimento do produto, desenho e desenvolvimento do processo, validação e retroalimentação.

Por necessidade de padronização de informações por parte da montadora, que gerencia centenas de fornecedores, foi criada uma planilha de APQP, a qual funciona como um relatório padronizado em que é informado o cumprimento ou não das atividades, de acordo com as etapas do projeto, por todos os fornecedores envolvidos.

Considerando que o documento da montadora utiliza simbologias muito específicas e com a finalidade de facilitar a leitura e interpretação dos dados para o leitor deste trabalho, a planilha de APQP da montadora foi padronizada em um formato único, considerando etapas que chamaremos de "etapas genéricas do projeto", permitindo posterior leitura gráfica. É importante esclarecer que este formato respeita a lógica original dos documentos em análise e as fases do APQP a que correspondem.

Como existe sobreposição de algumas atividades, em especial durante o desenvolvimento do produto e do processo, estas etapas foram unificadas em uma única, de forma que as atividades do projeto ficaram organizadas conforme apresentado no quadro 8.

Em cada etapa do projeto, algumas atividades devem ser finalizadas. Para a leitura da evolução dos projetos em relação ao que foi previamente planejado, foi possível elaborar uma tabela estabelecendo quantas atividades deveriam estar finalizadas. Esta tabela é utilizada nos estudos de caso para realização de um comparativo entre o planejado e o real. A finalização das atividades previstas no documento da montadora, que chamaremos de "planilha APQP", está apresentada no quadro 8.

O quadro 8 descreve, em sua primeira linha, as etapas do APQP conforme descrito no manual do APQP (CHRYSLER; FORD; GM, 2008). Na segunda linha, estão as etapas do APQP padronizadas pela autora, para fins deste estudo, a partir das etapas descritas no relatório da montadora. Na terceira linha, está descrito o formato 
de relatório da montadora, chamado aqui de "planilha APQP", e o número de atividades que deve ser finalizada em cada uma das etapas do APQP. Na linha seguinte, estão as atividades acumuladas que devem estar finalizadas em cada etapa do APQP.

Quadro 8 - Divisão de etapas do projeto para fins de organização deste estudo

\begin{tabular}{|c|c|c|c|c|c|c|c|c|c|}
\hline \multicolumn{7}{|c|}{ retroalimentação, avaliação e a ação corretiva } \\
\hline APQP (AIAG) & \multicolumn{3}{|c|}{ Planejamento } & \multicolumn{2}{|c|}{$\begin{array}{c}\text { Desenho e desenvolvimento do } \\
\text { Produto e do processo }\end{array}$} & $\begin{array}{l}\text { Validação } \\
\text { do Produto } \\
\text { e Processo }\end{array}$ & \multicolumn{3}{c|}{ Produção } \\
\hline $\begin{array}{c}\text { etapa do projeto para } \\
\text { fins de estudo }\end{array}$ & $\begin{array}{c}\text { definição de } \\
\text { fornecedores }\end{array}$ & $\begin{array}{c}\text { validacoes } \\
\text { de design }\end{array}$ & $\begin{array}{c}\text { definição } \\
\text { comercial }\end{array}$ & $\begin{array}{c}\text { finalização } \\
\text { de } \\
\text { engenharia }\end{array}$ & prototipo & $\begin{array}{c}\text { conclusão de } \\
\text { desenhos }\end{array}$ & $\begin{array}{c}\text { inicio da } \\
\text { producao }\end{array}$ & $\begin{array}{c}\text { aceleracao } \\
\text { producao }\end{array}$ & $\begin{array}{c}\text { producao em } \\
\text { ritmo } \\
\text { finalizacao } \\
\text { do projeto }\end{array}$ \\
\hline $\begin{array}{c}\text { No atividades previstas a } \\
\text { serem finalizadas por } \\
\text { etapa }\end{array}$ & 2 & 0 & 5 & 8 & 4 & 4 & 19 & 3 & 1 \\
\hline $\begin{array}{c}\text { Soma das atividades } \\
\text { finalizadas por etapa }\end{array}$ & 2 & 2 & 7 & 15 & 19 & 23 & 42 & 45 & 46 \\
\hline
\end{tabular}

Fonte: levantamento do autor

\subsubsection{Coleta de dados adicionais de outros projetos}

A partir dos casos analisados, algumas conclusões comuns aos dois projetos puderam ser extraídas. Com o objetivo avaliar se estas conclusões poderiam ser estendidas a outros projetos, foram analisados os documentos de APQP de 21 fornecedores do projeto de um novo veículo.

Quadro 9 - Coleta adicional de outros produtos - relação de produtos e fornecedores avaliados por segmento

\begin{tabular}{|c|c|c|}
\hline área do produto & $\begin{array}{c}\text { Número de } \\
\text { fornecedores }\end{array}$ & $\begin{array}{c}\text { número de produtos } \\
\text { analisados }\end{array}$ \\
\hline motorização & 3 & 47 \\
\hline carroceria & 9 & 67 \\
\hline estrutura chassis & 8 & 62 \\
\hline elétrica & 1 & 61 \\
\hline total & $\mathbf{2 1}$ & $\mathbf{2 3 7}$ \\
\hline
\end{tabular}


Fonte: levantamento do autor

Este projeto foi selecionado por tratar de um veículo novo e, consequentemente, ter um interesse estratégico tanto por parte da montadora como de seus fornecedores. Foram selecionados todos os 21 fornecedores considerados críticos pelos critérios da montadora. Foram analisadas as "planilhas APQP" dos produtos a serem fornecidos por estes fornecedores e foi avaliado se as mesmas conclusões extraídas dos casos anteriores poderiam ser estendidas a outros casos.

O quadro 9 mostra a classificação de segmento de aplicação do produto, número de fornecedores e produtos avaliados por segmento para os estudos apresentados neste capítulo.

\subsubsection{Entrevistas sobre o APQP para complementar entendimento do uso da metodologia}

Com a finalidade de entender melhor a importância, vantagens, desvantagens e dificuldades no uso do APQP, foi realizada uma pesquisa junto a profissionais envolvidos com o uso desta metodologia dentro da montadora. Os funcionários escolhidos não estavam necessariamente ligados aos casos estudados neste trabalho, mas foram selecionados por serem considerados os maiores conhecedores desta metodologia na montadora. Eles receberam um treinamento diferenciado para o uso de APQP e para utilização do padrão usado pela empresa. São os responsáveis por orientar os fornecedores e, em alguns casos, outros colaboradores internos da montadora, além de administrar e consolidar as informações recebidas nos APQPs. Foram entrevistados seis profissionais.

Nas entrevistas, foi utilizado um questionário semi-estruturado, apresentado no apêndice $B$, nos quais as seguintes questões foram levantadas: 1) quais as vantagens do uso do APQP; 2) quais as desvantagens do uso do APQP; 3) o que se faz necessário para que o APQP seja uma metodologia adequadamente aplicada; 4) quais são as dificuldades enfrentadas na aplicação da metodologia. 
Esta pesquisa se mostrou interessante para identificar se os problemas e dificuldades encontrados nos estudos de casos e que puderam ser gerenciados através do APQP ocorrem com frequência. Foi possível avaliar, também, se os profissionais entendem que o uso da ferramenta contribui para a gestão destas ocorrências e se existe um padrão para esta gestão.

As respostas foram organizadas e correlacionadas com aspectos extraídos dos estudos de caso. 


\section{ESTUDOS DE CASO}

Conforme descrito no capítulo 3, para o desenvolvimento dos estudos de caso foram selecionados dois projetos de um fornecedor de sistemas elétricos, com responsabilidade de desenvolvimento compartilhada entre montadora e fornecedor. Os dois estudos abordam desenvolvimentos ocorridos junto à mesma montadora de veículos, e serão apresentados nos capítulos 4.1.1 e 4.1.2.

O sistema elétrico é de fundamental importância para o veículo, pois dele dependem todas as funções que necessitam de condução de energia, como o acionamento do veículo, funcionamento do ar condicionado, do limpador de vidros, luzes externas, internas e de painel, além de muitas outras funções. Este produto é particularmente interessante, pois faz interface com muitos outros componentes. Por exemplo, o sistema elétrico do painel do veículo pode ter 70 interfaces somente de conexões, além diversas outras em seu percurso, como fixadores, proteções em regiões quentes ou cortantes. O sistema deve percorrer um trajeto entre uma conexão e outra, levando em conta características localizadas de temperatura, fixação para evitar ruídos, de segurança para não romper, entre outras, fazendo com que a arquitetura, e não apenas a função do produto, seja importante. O funcional do produto é considerado responsabilidade do fornecedor, porém alguns aspectos relacionados à definição de interfaces precisam ser de responsabilidade da montadora.

Além da importância do sistema elétrico para o veículo, este produto é interessante por se tratar de uma comoditie cujo processo de produção é complexo, por ter muitas atividades manuais e por ter uma logística muito complicada, em função da multiplicidade de combinações de componentes internos (um sistema elétrico principal chega a ser constituído por 400 componentes). Desta forma, existem poucos fabricantes deste produto no Brasil. Foram citados apenas quatro fabricantes, sendo todos multi-nacionais e com processos internos estruturados corporativamente. Foi citada uma montadora importante no mercado (entre as cinco maiores no Brasil) que apresentou dificuldades de negociações junto a estes 
fornecedores e, como consequência, atualmente apenas um fabricante de sistemas elétricos não se recusa a fornecer a este cliente. Isso deixa envidente a força de posicionamento que estes fabricantes possuem no mercado.

As entrevistas e levantamentos de dados foram feitas com os colaboradores integrantes da equipe da montadora, bem como da equipe do fornecedor, sendo que foram entrevistados gestores do processo e engenheiros de produto de ambas as empresas.

No capítulo 4.1.3, será apresentada uma análise geral de prazos do projeto a partir de um grupo maior de fornecedores. Para a realização deste estudo, foi escolhido o projeto do novo veículo e, dentro deste projeto, foram selecionados os 21 fornecedores considerados "críticos", segundo critério da própria montadora.

No capítulo 4.1.4, será apresentado um estudo junto aos profissionais que trabalham diretamente com o APQP dentro da montadora. Este estudo busca identificar a importância, vantagens, desvantagens e dificuldades no uso do APQP, segundo a visão destes profissionais, e comparar estas questões com os aspectos importantes identificados nos estudos de caso.

\subsection{Descrição dos projetos}

\subsubsection{Estudo de caso "1"}

O primeiro estudo de caso trata do desenvolvimento de um produto que está inserido em um projeto de pequeno porte dentro da montadora e que implica na inclusão de um novo sistema para o usuário final. Neste projeto, o fornecedor $\mathrm{A} 1$ teve que alterar o sistema elétrico fornecido para a montadora, a fim de permitir a alteração de outros sistemas interligados e a inclusão desta nova função no veículo. Será tratada, neste estudo, a alteração do sistema elétrico fornecido pela empresa fornecedora A1.

O cronograma do fornecedor deve atender ao cronograma da montadora, que tem duração prevista de sete meses, desde a entrada do fornecedor, por meio de uma 
oficialização contratual, até a finalização do processo de validação do produto, entrega do PPAP e emissão do documento PSW. Este é o período no qual é feito o acompanhamento do APQP e que é foco deste trabalho.

Este projeto tem outras particularidades. Além das mudanças de produtos relativas ao projeto em questão, foram inseridas diversas outras modificações, com a finalidade de obter melhorias no processo de montagem e também redução de custos. Existem, portanto, outras alterações simultâneas, mas não relacionadas diretamente ao programa.

Ao longo do desenvolvimento, foi observado que estas ações de melhoria eram necessárias, porém acabaram interferindo na velocidade de execução das ações e atrapalharam no atendimento aos prazos. Houve ainda outros fatores, que serão abordados abaixo. Foram analisados inicialmente os documentos que refletem as análises de APQP. Os acompanhamentos do APQP são documentados em planilhas, que chamaremos de "Planilhas de APQP". Esta planilha é, teoricamente, revisada pela empresa fornecedora pelo menos uma vez ao mês. Depois de revisada, a planilha deve ser encaminhada à montadora, que poderá fazer a análise do andamento do processo na planta do fornecedor ou apenas verificar o documento em papel. No projeto analisado, com sete meses de duração, deveriam estar disponíveis seis ou sete planilhas. Porém, devido a dois períodos de férias coletivas (relacionadas à crise mundial) e um atraso de mais de um mês para a entrada do fornecedor no projeto, só estavam disponíveis cinco planilhas.

O período de projeto, como foi descrito anteriormente, é definido a partir do cronograma da montadora, sendo que este, a princípio, é imutável. Desta forma, o programa da montadora prevê um período de desenvolvimento para o fornecedor, desde a sua entrada até a validação do produto e do processo final. Mesmo que ocorra algum atraso durante o projeto, o prazo final do fornecedor é mantido, de forma que o período de desenvolvimento do fornecedor acaba sendo sacrificado. Desta forma, mesmo que, por exemplo, a entrada do fornecedor atrase, não existe extensão oficial do prazo final da validação do processo do fornecedor, pois este prazo já foi pré-estabelecido dentro de um cronograma da montadora. 
O primeiro aspecto identificado neste projeto foi que, apesar de se tratar de um projeto curto, com um período de apenas sete meses para o fornecedor executar todas as ações que lhe são pertinentes, houve, já no início, um atraso de um mês e dez dias para a oficialização da entrada do fornecedor no projeto, fazendo que o período de desenvolvimento real do sistemista ficasse reduzido a menos de seis meses. Considerando a duração do programa, o tempo perdido no início corresponde a praticamente $20 \%$ do total. (1ำ problema identificado - atraso na entrada oficial do fornecedor no projeto).

Além do atraso no início do programa, outros problemas ocorreram, fazendo que mais etapas fossem comprometidas, acarretando um atraso geral no programa, como pode ser visto no gráfico 3. O gráfico compara a evolução planejada para o projeto e a evolução real, ao longo das etapas programadas.

Gráfico 3 - Comparativo de evolução projetada e real do projeto 1

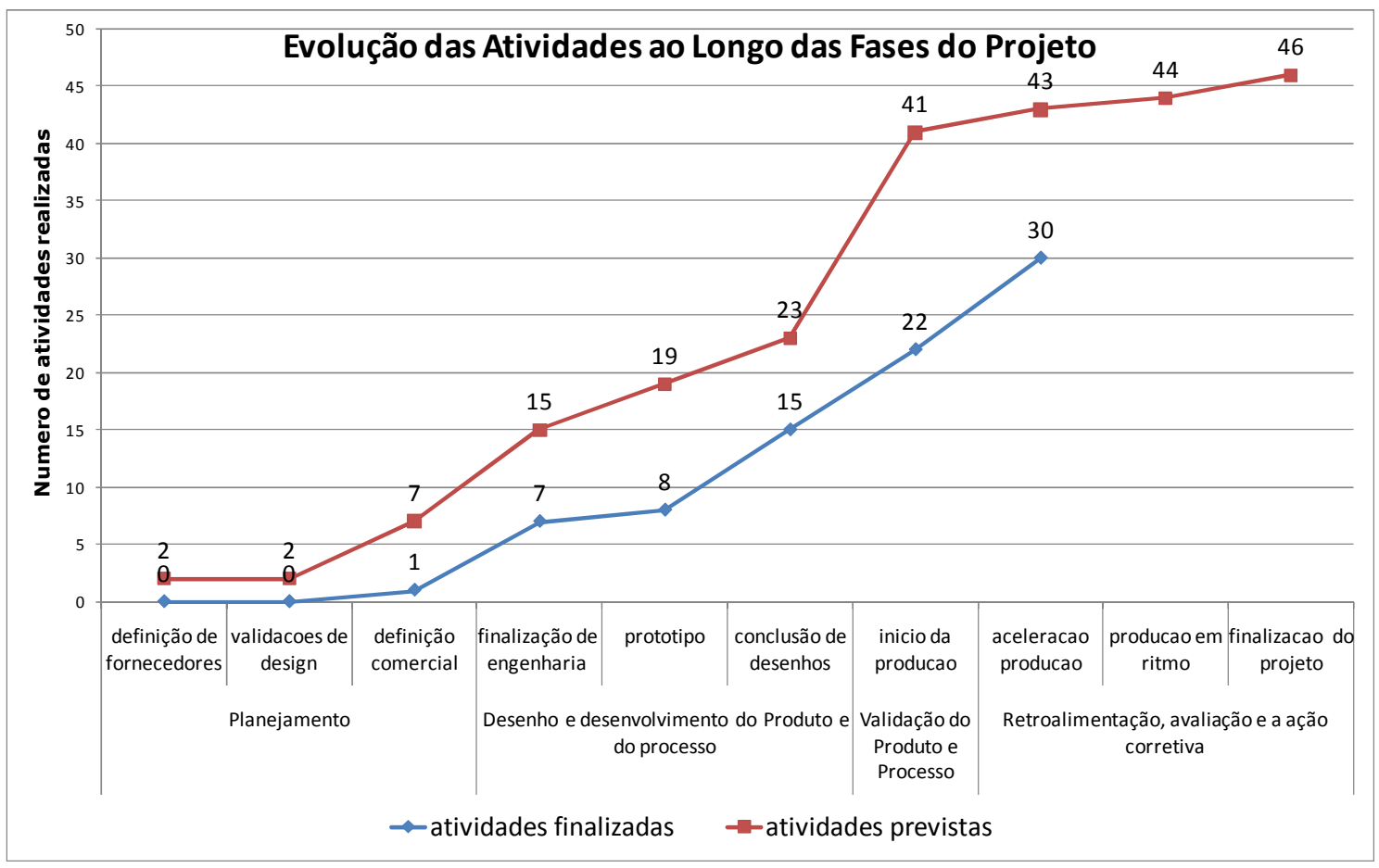

Fonte: levantamento do autor

Para a construção do gráfico, foram levadas em consideração primeiro as atividades do APQP que deveriam estar finalizadas para cada estágio do programa, conforme 
previamente esclarecido no item 3.4 e, então, as atividades que realmente foram finalizadas.

A análise dos documentos revela que atrasos em algumas atividades iniciais do projeto prejudicam 0 andamento de todo 0 processo, causando atrasos subsequentes que se sobrepõem, causando a impressão de estagnação. No caso estudado, houve atrasos de definições de engenharia com conseqüências nos acertos comerciais que possibilitam a construção dos meios de produção, como ferramentas, dispositivos e até a compra de matéria-prima e componentes. Assim, todo o processo ficou comprometido. As informações relativas às causas de atrasos e ações necessárias para 0 andamento do processo ficam documentadas na "planilha de APQP". A análise do documento revela que diversos itens em atraso resgatam sempre a mesma causa: "congelamento das ações de engenharia". (2ำ problema identificado - atraso nas definições de engenharia e início de construção de ferramental).

Quando a equipe interna de engenharia da montadora entrevistada foi questionada sobre as causas deste atraso, algumas justificativas particulares a este projeto foram feitas: junto às modificações do próprio projeto, havia outras modificações esperando para ser implementadas. Estas outras modificações, por sua vez, haviam sido impactadas por um projeto anterior, que fez com que houvesse um volume significativo de modificações pendentes. Algumas destas alterações se referiam a questões de ergonomia de montagem, outras de melhoria do produto e, finalmente, de redução de custos.

O projeto anterior, que causou impacto no projeto aqui estudado, ocorreu um ano antes do estudo, revelando um passivo de modificações acumuladas remanescentes de um trabalho com finalização inadequada. A causa deste problema pode estar na falha de simulações com protótipo, por meio das quais poderiam ter sido identificados problemas de montagem e ergonomia ou, também, falha no processo de retroalimentação e finalização de projeto. (3ำ problema identificado - falha nas ações de conclusão de um projeto - etapa 5 APQP).

A figura 10 mostra uma representação cronológica das ações do projeto de 2008 sendo aplicadas no projeto seguinte. Além das ações terem sido realizadas quase 
um ano depois, os dados estudados neste trabalho mostram que as ações de correção pendentes do projeto anterior, desenvolvido em 2008, causaram retardo no projeto de 2009, pois as mudanças não estavam adequadamente definidas e planejadas.

Figura 10 - Representação cronológica das ações nos projetos estudados no caso 1.

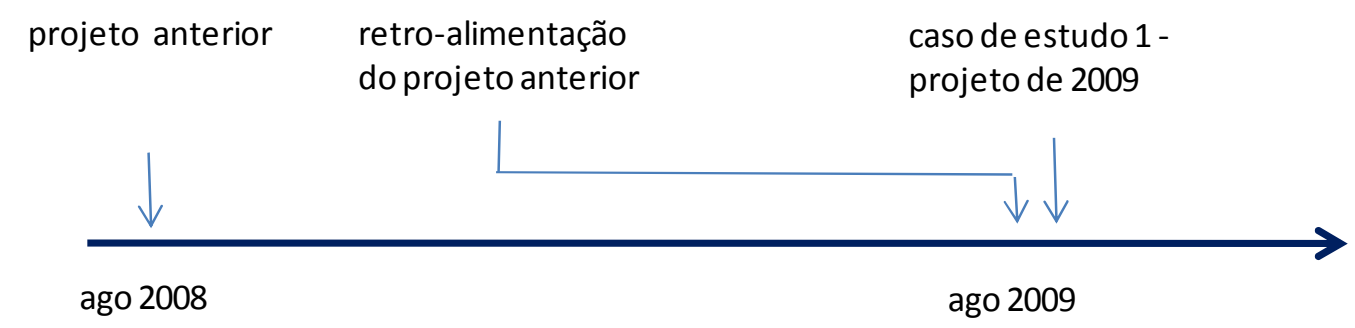

Fonte: levantamento do autor

Outro fator relacionado à engenharia que afetou a definição do sistema elétrico foi que o sistema a ser utilizado era novo para outros fornecedores, e houve atraso em definições de outros componentes devido ao fato de haver uma nova tecnologia envolvida. (4ำ problema identificado - falha no planejamento do prazo para desenvolvimento de uma nova tecnologia no fornecedor).

Um problema particular deste projeto, relatado pela equipe da própria montadora e também mencionado pela equipe de desenvolvimento do fornecedor, foi o fato de ele ter sido motivado por uma regulamentação imposta pelo governo, havendo, concomitantemente, a expectativa de que o mesmo projeto fosse cancelado. Este fato causou atrasos durante o processo de definições internas. (5ำ problema identificado - interferências de fatores externos às estratégias da montadora).

Objetivamente analisando as atividades em atraso relatadas no documento de APQP, estão "atraso na definição do projeto" de três meses e meio. Houve uma simultaneidade de ações, que permitiu que o atraso final da validação do processo ficasse reduzido a 45 dias. Esta recuperação de prazos, de dois meses, entre os atrasos de engenharia e o atraso na validação final pode ser considerada significativa, considerando um prazo total de projeto de sete meses. ( $1^{\circ}$ aspecto 
positivo identificado - o fornecedor conseguiu compensar parte dos atrasos da montadora)

No gráfico 3, podemos observar que, na fase de protótipo, existia um grande gap entre as atividades que deveriam estar concluídas e as que realmente estavam, fazendo com que os protótipos testados ainda não estivessem na fase final de desenvolvimento. (6ํㅜ problema identificado - protótipos não refletem o produto final).

$\mathrm{Na}$ fase de "validação do produto e processo", o gap entre atividades previstas e realizadas foi ainda maior. Apenas 22 de 43 atividades estavam concluídas. Teoricamente, esta etapa do APQP refere-se à validação final do produto e processo dentro do fornecedor. Neste momento, o produto deve atender a todas as especificações. A validação do processo garante que o item terá a mesma qualidade em todas as produções subseqüentes.. Estas validações devem estar documentadas em um conjunto de dados chamado "PPAP", apresentado no item 2.2.2 deste trabalho. Porém, como foi verificado, neste desenvolvimento as etapas sofreram atrasos, de forma que não houve possibilidade de atendimento ao prazo de validação final, considerado particularmente importante. Nesta etapa, devem ser entregues peças para montagens de validação do projeto também dentro da montadora. Como o processo não estava concluído no fornecedor e como as entregas devem ser feitas para atender à necessidade de montagem da montadora, foram entregues peças não validadas, com autorização de engenharia. ( $7^{\circ}$ problema identificado - primeiras peças de produção não foram validadas).

O gráfico mostra que na etapa seguinte houve uma interrupção. Cabe aqui um esclarecimento: o projeto é fundamentado em uma adequação à regulamentação governamental, o que não influencia a competitividade do veículo. Portanto, a montadora decidiu ajustar as datas de finalização do projeto com o início da aplicação da lei. No momento em que ocorriam as fases finais do projeto da montadora, quando se inicia a curva de aceleração de produção em massa, o governo postergou a data de entrada em vigor da nova lei por seis meses, fazendo que a montadora adiasse a conclusão do projeto. A colocação do projeto para produção em massa foi postergada em seis meses, fazendo que o cronograma da montadora, relativo a esta fase, fosse readequado. 
Todas as etapas seguintes que devem ser realizadas para a conclusão do projeto em questão estavam atrasadas em aproximadamente 45 dias, porém, com o tempo adicional de seis meses que o projeto recebeu, os prazos seguintes se tornaram possíveis de serem atendidos.

Como a finalização deste projeto foi postergada por seis meses, a análise do mesmo para este trabalho com fins didáticos será finalizada aqui, por falta de mais dados.

Durante as entrevistas e análises de documentos foi possível identificar um problema conceitual na aplicação da metodologia do APQP. Avaliando a função do método, temos a seguinte consideração: o APQP é um sistema de orientação para a validação do produto e do processo de produção de um novo produto. Toda esta avaliação está ligada a um fluxo de desenvolvimento, particular de cada empresa.

A finalização de todo este processo é consolidada em um conjunto de documentos chamado pelas montadoras americanas de PPAP e cujo certificado de aprovação final é o PSW.

A data de emissão do certificado "PSW" é um marco esperado pelo time de projeto, de forma que o monitoramento para o cumprimento de seu prazo recebe atenção especial. A informação do atendimento a este prazo consta na planilha de APQP. Este prazo é acompanhado pelo time e pela gerência do projeto do fornecedor e, dentro da montadora, pela equipe de qualidade de engenharia, engenheiros de produtos e pelo time que faz o controle geral do programa, entre outros. O APQP fornece a visão da data de PSW prevista pelo fornecedor, pois apresenta a evolução de todo o processo de validação e, assim, demonstra quando este processo será concluído e, por fim, quando será emitido o documento que comprova a conclusão do processo, o PSW.

Porém, é necessário esclarecer que, para a equipe de engenharia e qualidade da montadora que faz o acompanhamento junto ao fornecedor, o APQP busca orientar o processo de validação, considerando os prazos disponíveis no projeto. De acordo com a teoria verificada no item 2.2, o APQP, fundamentalmente, não é um cronograma e não foi desenvolvido para ser usado como um veículo para definição de prazos vitais ao programa. O APQP deve apresentar os prazos de finalização de 
atividades suportes ao projeto e que estão relacionadas à validação da qualidade do produto e do processo do fornecedor.

Os prazos vitais do projeto dentro do fornecedor são definidos pela montadora, por meio de sistemas complexos de desenvolvimento de produto. Deve-se criar o cronograma completo das atividades considerando a complexidade dos diversos departamentos, inclusive, é claro, a questão do fornecimento de peças.

Ocorre que, em determinado momento, as entregas de engenharia perdem os prazos definidos no cronograma da montadora, teoricamente comprometendo as métricas e podendo afetar o prazo final do programa.

Como já foi dito, os prazos de entrega do PSW são muito importantes para toda a equipe envolvida no projeto. Quando prazos intermediários da engenharia são comprometidos, o time da engenharia da montadora deixa de buscar atender ao cumprimento das atividades de cada etapa do projeto, ou "gate", baseado no cronograma da montadora, e passa a se organizar a partir do cronograma do fornecedor. Desta forma, o fornecedor começa a orientar os prazos finais para que a montadora lhe entregue o desenho do produto, além de outras informações, para que possa realizar seu processo e manter atendida a data de entrega do documento PSW. (8º problema identificado - APQP substituindo referências de prazos do cronograma da montadora).

A gestão de atividades e datas fica invertida. Ao invés da montadora dar os prazos para o fornecedor, este começa a orientar os prazos da montadora. A pergunta passa a ser: qual é a última data possível para que o fornecedor receba as informações, sem alterar a entrega de PSW? Este é o momento em que se abre espaço para que o fornecedor seja pressionado para se ajustar aos prazos e necessidades da montadora.

No caso estudado, o fornecedor teria seis meses para realizar todo o seu processo, desde a definição e aquisição de componentes e matéria prima, a construção dos meios de produção e validação final do produto e processo. Porém, para isso ser possível, algumas informações de engenharia precisariam ter sido fornecidas no início do processo. Como este prazo não foi cumprido, iniciou-se um processo de 
negociação. Entre as questões em jogo, estavam: negociação para que o fornecedor começasse a trabalhar com uma "engenharia simultânea forçada", iniciando o seu trabalho com informações de engenharia aquém das que deveria ter e, além disso, com a falta de conclusão da negociação comercial. Outra negociação foi a redução do tempo de trabalho do fornecedor para a conclusão do projeto. Como o fornecedor é o elo mais fraco desta cadeia, existe uma pressão forte para a redução de prazos e entrega do PSW, fazendo que sejam reduzidos prazos internos para atender ao cliente. (9ำ problema identificado - redução dos prazos de validação do produto e processo dentro do fornecedor).

Neste caso estudado, o processo que o fornecedor deveria ter executado em seis meses, após formalização do pedido de compra, foi reduzido para três meses e meio. O prazo final excedeu em um mês o objetivo inicial, acarretando atraso em todo o projeto final. Isso foi possível pois o fornecedor começou a trabalhar antes do pedido de compra emitido e antes de ter as informações formais sobre o produto. (10- problema identificado - fornecedor começa a trabalhar antecipadamente, sem consentimento da montadora a assumindo riscos para poder atender prazos).

Quadro 10 - Dificuldades e aspectos positivos do caso 1

\begin{tabular}{|c|c|c|}
\hline & Dificuldades encontradas & Aspectos Positivos \\
\hline $\begin{array}{l}1 . \\
2 . \\
3 . \\
4 .\end{array}$ & $\begin{array}{l}\text { atraso na entrada oficial do fornecedor no projeto } \\
\text { atraso nas definições de engenharia e inicio de } \\
\text { construção de ferramental } \\
\text { falha nas ações de conclusão de um projeto - etapa } 5 \\
\text { APQP } \\
\text { falha no planejamento do prazo para desenvolvimento } \\
\text { de uma nova tecnoloaia no fornecedor }\end{array}$ & \\
\hline $\begin{array}{l}5 . \\
6 . \\
7 . \\
8 . \\
9 . \\
10 .\end{array}$ & $\begin{array}{l}\text { interferências de fatores externos às estratégias da } \\
\text { montadora } \\
\text { protótipos não refletem o produto final } \\
\text { primeiras peças de produção não foram validadas } \\
\text { APQP substituindo referências de prazos do } \\
\text { cronograma da montadora } \\
\text { redução dos prazos de validação do produto e } \\
\text { processo dentro do fornecedor } \\
\text { fornecedor começa a trabalhar antecipadamente, sem } \\
\text { consentimento da montadora a assumindo riscos para } \\
\text { poder atender prazos }\end{array}$ & $\begin{array}{l}\text { Forte interação entre fornecedor e } \\
\text { engenharia da montadora permitindo } \\
\text { realização de atividades em paralelo e } \\
\text { recuperação de parte dos atrasos }\end{array}$ \\
\hline
\end{tabular}

Fonte: levantamento do autor 
Alguns profissionais da área da qualidade da montadora e do fornecedor alegam que as reduções de prazo comprometem as análises de validação, que é o objetivo principal do APQP. Além disso, a função do APQP, que seria de "orientar e direcionar a validação do processo", fica distorcida, e ele se torna um "cronograma inverso de quanto tempo demora para fazer a validação", direcionando os prazos limites para conclusão de etapas anteriores. Os esforços e preocupações com prazos acabam consumindo o trabalho que deveria ser direcionado para a validação do produto e processo.

O quadro 10 ilustra um resumo das dificuldades e aspectos positivos.

\section{Tipo de abordagem do projeto}

O projeto em questão, apesar de ter uma nova tecnologia envolvida em outros componentes do veículo, foi composto por apenas um incremento para o fornecedor que estamos analisando. Portanto, este pode ser considerado um projeto "incremental ou derivado", segundo a proposta de tipos de abordagens feita por Rozenfeld et al. (2006).

\section{Gestão do projeto}

Segundo aspectos discutidos por Kerzner (1987) relacionados à excelência em gestão de projetos, podemos fazer algumas observações:

1. Projeto dentro do tempo - apesar de ser observado atraso em todas as etapas do projeto, e do APQP ter uma atuação limitada para influenciar a finalização das atividades da montadora, pode-se observar que o gerenciamento das atividades, análises de prazos e discussões proporcionaram oportunidades para que houvesse adaptações e acordos. Estes acordos permitiram realizações de atividades simultâneas entre cliente e fornecedor que resultaram em uma redução nos atrasos finais do projeto. Três meses e meio de atrasos na montadora acarretaram apenas um no fornecedor. Isso foi possível pois o fornecedor trabalhou em paralelo com a montadora, fazendo investimentos antecipados, assumindo riscos de prejuízo e até mesmo evitando procedimentos corporativos de ambas as empresas. 
2. Dentro do custo ou orçamento - este item pode ser diretamente afetado pelos itens 1 e 3, pois atrasos e problemas de qualidade estão estritamente relacionados a custos. Além disso, para a recuperação de alguns atrasos, a equipe de coordenação de projeto do fornecedor relatou esforços não programados, como horas extras e embarques aéreos de matéria-prima, por exemplo.

3. Dentro do desempenho ou performance desejada - ocorreram entregas de peças sem o processo de produção finalizado e validado. Como consequência, ocorreram três falhas em produtos, os quais precisaram ser retrabalhados. As falhas precisaram ser justificada por meio de documento formal, e todas tiveram como justificativa problemas de comunicação entre desenho do produto e desenho do processo do produto. Esta questão teria sido evitada em um processo de validação normal, pois as falhas teriam sido identificadas no fornecedor, por meio de validações de peças padrão e teste elétrico de final de linha, impedindo que o produto chegasse à linha de montagem do cliente final. Desta forma, problemas de qualidade ocorreram como consequência da não aplicação das disciplinas do APQP, dentro do prazo pré-estabelecido no projeto.

4. Dentro da aplicação original ou mudanças acordadas - ocorreram mudanças que foram sendo acordadas ao longo do projeto. O APQP se mostrou um documento útil para comunicar questões, dificuldades ou pendências destas propostas, envolvendo outros departamentos, quando necessário.

6. Bem documentado, com avaliação endereçada - foi possível constatar que, ao longo do desenvolvimento, ocorreram registros de atas internas do fornecedor, bem como comunicação via documento APQP, além de trocas de e-mails que buscaram tanto alinhar informações como sinalizar dificuldades, principalmente relacionadas a prazos. A finalização do processo, feita por meio da documentação PPAP, obriga o fornecedor a ter a validação bem documentada. Houve, porém, certa dificuldade em examinar os documentos com registros de resultados do projeto.

\section{Estágio de desenvolvimento do relacionamento}

As características funcionais de interface do produto são estabelecidas pela montadora, que define, também, alguns dos componentes. O fornecedor foi 
responsável por definir parte do conjunto de componentes internos que possibilitarão atender à arquitetura e funções solicitadas. Parte dos itens é detalhada e parte black box, aproveitando registro de desenhos do histórico do sistema.

O fornecedor recebe especificações críticas na maior parte dos casos, mas também recebe especificações detalhadas sobre algumas características de componentes do produto, sem um critério claro sobre o que deve e não deve ter maior detalhamento.

O fornecedor tem influência nas especificações dos componentes, desde que atendam ao funcional. O fornecedor se envolveu durante a etapa de definição do conceito. A responsabilidade sobre o teste dos componentes é integralmente do provedo, que detém entre média e ampla capacidade tecnológica.

A partir da abordagem de Kamath e Liker (1994) apud Moreira (2005), em alguns aspectos, como design e complexidade do produto, o relacionamento pode ser classificado como envolvimento, porém, em outros, como especificações, estágio em que o fornecedor se envolve e responsabilidade sobre testes, pode ser considerada como maturidade.

\section{Fornecedores e o processo de engenharia}

A partir da classificação proposta por Clark e Fujimoto (1991), os produtos estão em um estágio intermediário entre black box e peças controladas, pois algumas características do produto são mais bem detalhadas e outras, como alguns dos componentes, são black box.

\section{Arranjos organizacionais - análise comum para os dois projetos}

A empresa A1 analisada tanto no projeto 1 como no projeto 2 tem uma estrutura de engenharia separada da estrutura de manufatura. São duas unidades de negócios distintas e fisicamente distantes: engenharia de produto e manufatura.

Existe um gerente de projeto dentro da engenharia de produto, que é responsável pelo gerenciamento geral do projeto. Porém, como ele não faz parte da estrutura da manufatura, há também uma equipe de coordenação do projeto dentro da manufatura. Assim, nesta empresa, existem duas coordenações de projeto, uma na 
engenharia, com título de gerente de projeto e atuação mais voltada às questões de definição de produto, desenho, do produto final e de componentes. A outra coordenação está na manufatura, e é responsável pelas atividades dos diversos departamentos relacionados às áreas de processos, qualidade de manufatura, produção, testes de validação do processo, compras, entre outras.

Esta equipe de manufatura passou por uma transição na estrutura de projetos. A mudança na área de manufatura surgiu ao longo do ano de 2009. Inicialmente, a equipe de projeto era integralmente funcional, ou seja, todos respondiam a um líder funcional e realizavam atividades do projeto sob a coordenação de um departamento. Na nova configuração proposta pela empresa, a estrutura passa a ter uma configuração mais próxima da matricial, embora não esteja claramente enquadrada no modelo proposto por Rozenfeld et al. (2006). Isso porque existe um departamento de coordenação de projeto, com um gerente do departamento de coordenação do projeto, um coordenador e uma equipe dedicada ao projeto. Porém, a equipe responde ao gerente do departamento de coordenação do projeto, e não ao coordenador do projeto ou ao gerente funcional.

Figura 11 - Estrutura de projetos da empresa A1

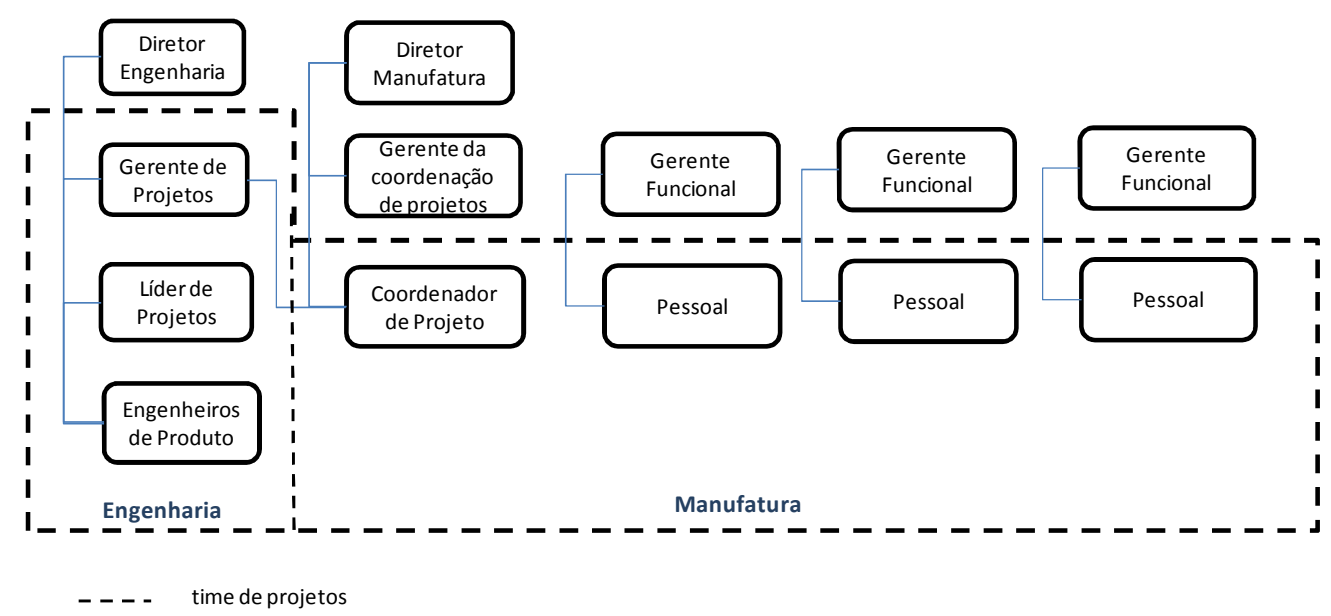

Fonte: levantamento do autor

$\mathrm{Na}$ manufatura, os coordenadores de projeto possuem nível hierárquico inferior ao do gerente de projeto da engenharia de produto e o mesmo nível hierárquico dos demais integrantes da equipe. Caracterizam, portanto, uma variação do tipo de 
estrutura matricial proposto por Rozenfeld et al. (2006), com um "gerente de projeto" peso leve.

$\mathrm{Na}$ engenharia, existe um gerente de projeto que tem relação direta com o coordenador de projeto, mas não exerce relação hierárquica com a estrutura de manufatura. A figura 11 mostra a estrutura encontrada na empresa A1.

\subsubsection{Estudo de caso "2"}

O segundo estudo de caso trata do desenvolvimento de um produto que está inserido em um projeto de grande porte dentro da montadora, um veículo novo. Este lançamento trará uma nova plataforma para a montadora local, porém o projeto está sendo copiado de um já existente em outro país. Mesmo assim, o sistema elétrico do veículo original será pouco aproveitado, pois, além de o sistema elétrico incorporar todas as alterações necessárias para a localização do veículo, e de a montagem e ergonomia da operação serem particulares do processo da fábrica local, o roteiro original do sistema não foi fornecido ao Brasil, mas apenas as interfaces elétricas com os componentes. Deste modo, o fornecedor foi convidado a desenvolver todo o projeto com a montadora, de forma que as informações das interfaces com outros componentes devem ser fornecidas pela empresa cliente e o roteiro do sistema elétrico deve ser desenvolvido pelo fornecedor. Como o desenvolvimento colaborativo foi definido desde o início do projeto, o fornecedor também auxilia a solução de problemas de interfaces com outros componentes, porém a responsabilidade primeira é da montadora.

O cronograma do fornecedor, assim como no primeiro caso, deve atender ao cronograma da montadora, que tem duração prevista de 18 meses, desde a entrada do fornecedor, que deve acontecer através de uma oficialização contratual, até a finalização do processo de validação do produto, entrega do PPAP e emissão do documento PSW. Este é o período no qual é feito o acompanhamento do APQP e que é foco deste trabalho. O projeto dentro da montadora tem uma duração maior, 
pois se inicia antes da definição do fornecedor e termina após as atividades de processo do fornecedor.

Assim como no outro projeto, foram analisados, inicialmente, os documentos que refletem as análises de APQP, as "planilhas de APQP". Estas são, teoricamente, revisadas pela empresa fornecedora pelo menos uma vez ao mês. Depois de revisadas, as planilhas devem ser encaminhadas à montadora, que poderá fazer a análise do andamento do processo na planta do fornecedor ou apenas verificar o documento em papel.

Este projeto ainda está em desenvolvimento, de forma que foram disponibilizadas para o estudo planilhas em estágio de definições de engenharia do projeto.

A "planilhas de APQP" foram recentemente incorporadas na montadora, junto a um novo processo de desenvolvimento de produto.

Como em qualquer projeto de uma grande corporação, o período de projeto é definido a partir do cronograma da montadora, sendo que este, a princípio, é imutável. Desta forma, o programa da montadora prevê um período de desenvolvimento para o fornecedor, desde a sua entrada até a validação do produto e do processo final.

O fornecedor considera os prazos da montadora, para este projeto, restritos, de forma que o acompanhamento do projeto é importante para gerenciar as dificuldades. Porém, a análise dos documentos revela que, desde a etapa inicial do projeto, que foi verificada neste estudo, já é possível verificar atrasos, como é possível acompanhar no gráfico 4.

Nos documentos e em entrevista com envolvidos no projeto dentro do fornecedor, foi possível constatar que o prazo da montadora entre congelamento de desenho e a montagem de peças protótipos é significativamente curto para o sistemista, tornando crítico o prazo das atividades internas do fornecedor. (1ำ problema identificado prazo para construção do protótipo inadequado para a necessidade do fornecedor).

Foi constatado, a partir das mesmas análises, que ocorre atraso no pedido de compras e no congelamento do design, o que implica, necessariamente, problemas 
para a construção do protótipo e, portanto, para etapas subsequentes do projeto. A equipe de projeto demonstrou muita preocupação com a questão. ( $2^{\circ}$ problema identificado - atraso nas definições comerciais e técnicas para construção do protótipo).

Gráfico 4 - Comparativo de evolução projetada e real do projeto 2

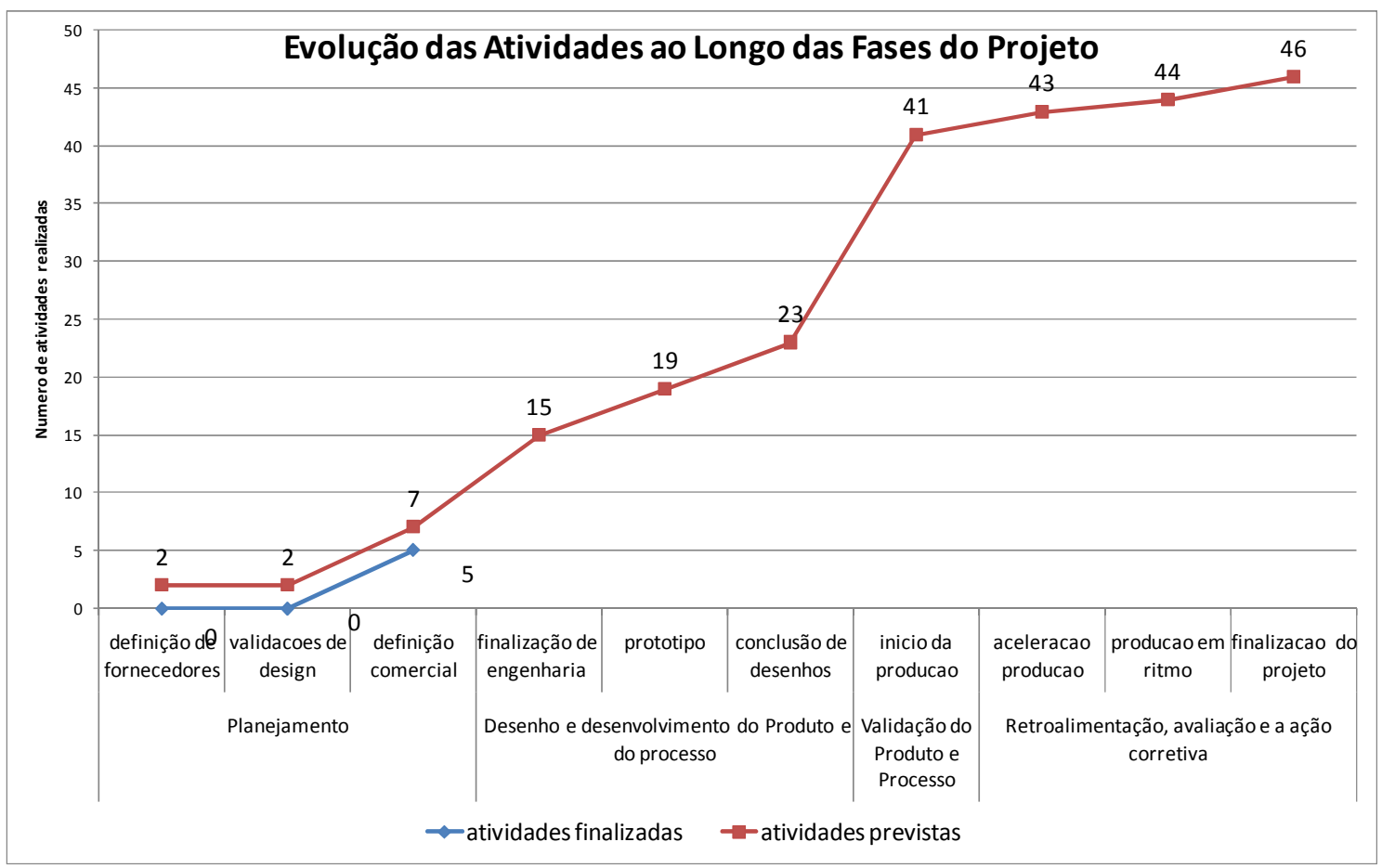

Fonte: levantamento do autor

Como este projeto ainda está em fase de engenharia e como o problema do projeto, até o momento, é o mesmo do projeto anterior (atrasos definições de engenharia), foi necessário aprofundar um pouco mais as questões que estão contribuindo para surgirem estas dificuldades.

Entre os problemas citados, estão atrasos em definições do sistema lógico, ou seja, das interfaces com outros produtos. Isso ocorreu porque faltaram definições de outros componentes que fazem a interface com o sistema elétrico. Sem estas interfaces definidas, não é possível definir o sistema elétrico. Além disso, ocorreram dezenas de problemas de interfaces com outros componentes do veículo devido ao roteiro da fiação na fase de análises virtuais. Isso ocorre pois, como foi explicado anteriormente, o sistema elétrico tem a complexidade de percorrer trajetos dentro do 
veículo, devendo se adequar a questões de temperatura, fixação para evitar ruídos, de segurança para não romper, desviar de componentes, entre outras, fazendo que a arquitetura ou roteiro, e não apenas a função do produto, seja importante. (3ำ problema identificado - atrasos em definições de interfaces prejudicando o produto em estudo).

Foram identificados, já nos testes virtuais do projeto, dezenas de problemas, que tiveram de ser resolvidos. Devido ao grande número de problemas e às dificuldades de solução de questões envolvendo outros componentes, houve atraso nas definições de interfaces. Como as ações de engenharia são geridas em um único "pacote", enquanto definições de desenho não são concluídas os ferramentais também não podem ser iniciados, gerando atraso em todo o sistema, que será refletido ao longo do projeto.

Em entrevista com engenheiros responsáveis pelo projeto, na montadora, foi identificado que os testes virtuais não puderam refletir toda a realidade do produto, uma vez que nem todas as interfaces estavam definidas, fato que pode ter conseqüências em etapas futuras do projeto. Dentro da estrutura de desenvolvimento do produto da montadora, esta etapa de testes virtuais é importante para a validação do produto. Sem refletir um produto na íntegra, as validações ficam prejudicadas. (4ํㅜ problema identificado - testes virtuais não refletiram o produto a ser utilizado).

Outro problema identificado foi que o prazo fornecido pela montadora para a realização de todas as etapas anteriores à construção do protótipo foi descrito pelo fornecedor como inviável. Desta forma, também neste projeto, o fornecedor adiantou algumas atividades, antes mesmo de ter definições comerciais formais, assumindo o risco de ter prejuízos. Sem estas iniciativas, o fornecedor declara que seria impossível atender à construção das peças da fase de protótipo. (5ำ problema identificado - em função de prazos estreitos, o fornecedor adianta processos de aquisição e assume riscos de prejuízos).

Após a definição comercial e consolidação de desenho, o fornecedor possui menos de seis meses para adquirir componentes, construir ferramentais, produzir os protótipos, validar e encaminhá-los ao cliente. Ocorre que muitos dos componentes 
deste fornecedor são importados, e os ferramentais dependem da existência dos componentes para serem construídos. Além disso, todo o sistema elétrico pode ter em torno de 300 componentes e a administração destas informações é complexa. Por iniciativa própria, o fornecedor compra alguns dos componentes previstos pela engenharia, para agilizar a construção de ferramentais, antes mesmo de o design estar definido. No estágio do projeto em que foram realizadas as entrevistas, 0 design ainda não estava "congelado" e alguns dos componentes, que haviam sido comprados para adiantar a construção do protótipo, já haviam se tornado obsoletos devido a consecutivas mudanças nas definições de interfaces com outros componentes. Mesmo o fornecedor tendo estes prejuízos, o gerente de projetos declara que é a única maneira de ter o produto disponível no prazo necessário do cliente.

Quadro 11 - Dificuldades e aspectos positivos do caso 2

\begin{tabular}{|l|l|l|}
\hline \multicolumn{2}{|c|}{ Dificuldades encontradas } & Aspectos Positivos \\
\hline 1. & $\begin{array}{l}\text { prazo para construção do protótipo inadequado para a } \\
\text { necessidade do fornecedor }\end{array}$ & $\begin{array}{l}\text { atraso nas definições comerciais e técnicas para } \\
\text { construção do protótipo } \\
\text { atrasos em definições de interfaces prejudicando o } \\
\text { produto em estudo } \\
\text { como testes virtuais embora realizados com } \\
\text { produtos ainda não 100\% representativos, } \\
\text { mostraram problemas que refletiram em } \\
\text { ações, que poderão minimizar dificuldades } \\
\text { posteriores. }\end{array}$ \\
4. & $\begin{array}{l}\text { em função de prazos estreitos o fornecedor adianta } \\
\text { processos de aquisição e assume riscos de prejuízos }\end{array}$ & $\begin{array}{l}\text { 2. Forte interação com a engenharia } \\
\text { permitindo realização de atividades em } \\
\text { paralelo e recuperação de parte dos atrasos }\end{array}$ \\
6. & protótipos físicos não refletem o produto final & \\
\hline
\end{tabular}

Fonte: levantamento do autor

O congelamento dos desenhos relacionados às interfaces existentes com o sistema elétrico não foi feito a tempo de definir o sistema elétrico para a fase do protótipo físico, fase posterior aos testes virtuais. Os engenheiros de sistemas elétricos, então, fizeram levantamentos de características dos componentes de interfaces, para poder sugerir definições no seu produto, e concluir o design. Estas definições, embora possam ser consideradas eficientes para o funcionamento do produto, revelam uma fragilidade no sistema de engenharia, pois o desenho do protótipo possivelmente não irá corresponder ao produto final. (6º problema identificado - protótipos físicos não refletem o produto final). 
Como o protótipo será o instrumento de validação física do projeto, na qual serão realizadas montagens no veículo, além de testes de validação e durabilidade, é possível que, sem estas definições concretas, apareçam dificuldades em etapas posteriores do projeto.

O quadro 11 ilustra um resumo das dificuldades e aspectos positivos.

\section{Tipo de abordagem do projeto}

Segundo a proposta de tipos de abordagens feita por Rozenfeld et al. (2006), este projeto seria do tipo follow-source, pois vem de outras unidades do grupo e não requer alterações significativas. Porém, como não vem com todas as soluções tecnológicas, ele possui algumas características de projeto do tipo plataforma, ou próxima geração. Em relação ao produto atual de linha, ele requer algumas alterações no projeto do produto e/ ou do processo sem, porém, exigir a introdução de novas tecnologias ou materiais.

\section{Gestão do projeto}

Segundo aspectos discutidos por Kerzner (1987) relacionados à excelência em gestão de projetos, podemos fazer algumas observações:

1. Projeto dentro do tempo - neste projeto ainda não é possível discutir atrasos conclusivos, porém já é possível observar atrasos em algumas etapas, que podem ser consideradas significativas, pois fazem parte de definições e validações de engenharia, como atraso nas definições do produto para testes virtuais e para peças protótipo com fins de testes de durabilidade.

2. Dentro do custo ou orçamento - apesar de estar no início do projeto, o fornecedor já consegue levantar prejuízos resultantes de atrasos de definições de engenharia. Isso ocorre porque foram adquiridos lotes de componentes importados, geralmente em grandes quantidades, que se tornaram obsoletos ao decorrer da definição do design. Não é possível dizer se este tipo de custo está previsto no orçamento do fornecedor, mas podemos afirmar que, sendo custo do cliente ou do fornecedor, é um desperdício. 
3. Dentro do desempenho ou performance desejada - as fases de engenharia contemplam validações e são previstas necessidades de ajustes no produto, consideradas ocorrências saudáveis. Desta forma, mesmo havendo problemas de interfaces durante testes virtuais, estes não podem ser declarados problemas de desempenho. É possível dizer, porém, que indefinições de produto que vão para testes virtuais ou de bancada podem estar comprometendo a confiança nos resultados destes testes.

4. Dentro da aplicação original ou mudanças acordadas - mudanças estão ocorrendo na fase de definição do produto e os documentos mostram que elas são planejadas e executadas em conjunto por fornecedor e cliente.

5. Bem documentado, com avaliação endereçada - é possível constatar que, ao longo do desenvolvimento, ocorrem registros de atas internas do fornecedor, bem como comunicação via documento APQP, além de trocas de e-mails que buscaram tanto alinhar informações, como sinalizar dificuldades, principalmente relacionadas a prazos.

\section{Estágio de desenvolvimento do relacionamento}

O sistema lógico do conjunto, ou seja, as características funcionais de interface do produto, é estabelecido pela montadora, que define ainda alguns dos componentes. O fornecedor é responsável por definir todo o sistema físico, ou seja, a arquitetura completa de conjunto, a maior parte dos componentes internos que possibilitarão as funções solicitadas. Parte dos componentes é detalhada e parte é tipo black box, aproveitando registro de desenhos do histórico do sistema.

O fornecedor tem grande influência nas especificações, sobretudo dos componentes, desde que atendam ao funcional. O fornecedor está envolvido desde o início do conceito.

A responsabilidade sobre o teste dos componentes é integralmente do fornecedor. Segundo Kamath e Liker (1994) apud Moreira (2005), a capacidade tecnológica do fornecedor pode ser considerada entre média e ampla e, em alguns aspectos, como design e complexidade do produto, o relacionamento pode ser classificado como envolvimento. $\mathrm{O}$ relacionamento relacionado às especificações, estágio em que o 
fornecedor se envolve, responsabilidade sobre testes, pode ser considerada como maturidade.

\section{Fornecedores e o processo de engenharia}

A partir da classificação proposta por Clark e Fujimoto (1991), apesar de o fornecedor desenhar o design do produto, também, neste caso, as peças estão em um estágio intermediário entre back box e peças controladas. O fornecedor irá desenhar o produto, mas o mesmo não será do tipo black box. Algumas características serão detalhadas em um desenho que será aprovado pela montadora, outras características, principalmente os componentes, serão black box.

\subsubsection{Análise complementar de outros projetos}

Praticamente todos os problemas identificados nos estudos de caso que estão no escopo de atuação da montadora são referentes a prazos, ou são consequência de problemas com prazos.

Com o objetivo de avaliar se os aspectos relacionados a prazos encontrados nos casos 1 e 2 poderiam ser verificados em outros desenvolvimentos de produtos, junto a outros fornecedores, foram coletadas planilhas de outros 21 sistemistas e foi analisado se ocorriam atrasos nos desenvolvimentos dos produtos.

Para a realização desta análise, foi selecionado o projeto de um novo veículo dentro da mesma montadora e foram selecionados os 21 fornecedores considerados críticos neste projeto. Foram analisadas as planilhas de todos os produtos fornecidos por estes fornecedores.

Os critérios da montadora para a classificação destes fornecedores como críticos são: complexidade do produto, prazo de desenvolvimento do produto, histórico do fornecedor em outros desenvolvimentos. 
As análises dos documentos APQP foram realizadas na etapa do projeto em que se finaliza a definição de design para a construção de veículos protótipos. Esta etapa está na da fase 2 do APQP estudada no capítulo 2.1.1.

Foram analisados 237 produtos de 21 fornecedores. Foram verificadas as conformidades e não conformidades relatadas do andamento do projeto em relação ao planejado. Foram observados os seguintes dados: $77 \%$ dos produtos reportaram algum tipo de atraso. Entre as justificativas mais comuns, estavam: atraso nas definições de design, sendo que $62 \%$ dos casos demonstraram este problema; $47 \%$ dos casos reportaram atrasos em liberação comercial de ferramental; e 30\% reportaram falta de definição de design e liberação comercial para construção de ferramental. Os resultados analisados podem ser observados no quadro 12.

Quadro 12 - Análise de prazos nos produtos considerados críticos para o projeto

\begin{tabular}{|c|c|c|c|c|c|c|c|}
\hline área do produto & $\begin{array}{l}\text { Número de } \\
\text { fornecedores }\end{array}$ & $\begin{array}{l}\text { Número de } \\
\text { planilhas } \\
\text { analisadas }\end{array}$ & $\begin{array}{l}\text { número de } \\
\text { produtos } \\
\text { analisados }\end{array}$ & $\begin{array}{c}\% \text { produtos sem } \\
\text { atrasos }\end{array}$ & $\begin{array}{c}\text { \% de produtos } \\
\text { com atrasos em } \\
\text { definição } \\
\text { comercial }\end{array}$ & $\begin{array}{c}\text { \% de produtos } \\
\text { com atrasos em } \\
\text { definições de } \\
\text { engenharia }\end{array}$ & $\begin{array}{l}\% \text { total de } \\
\text { produtos com } \\
\text { algum atraso }\end{array}$ \\
\hline motorização & 3 & 19 & 47 & $32 \%$ & $50 \%$ & $17 \%$ & $68 \%$ \\
\hline carroceria & 9 & 29 & 67 & $14 \%$ & $72 \%$ & $70 \%$ & $86 \%$ \\
\hline estrutura chassis & 8 & 28 & 62 & $39 \%$ & $10 \%$ & $25 \%$ & $61 \%$ \\
\hline elétrica & 1 & 18 & 61 & $6 \%$ & $0 \%$ & $100 \%$ & $94 \%$ \\
\hline total & 21 & 94 & 237 & $23 \%$ & $47 \%$ & $62 \%$ & $77 \%$ \\
\hline
\end{tabular}

Fonte: levantamento do autor

Desta forma, as observações de atrasos em projetos extraídas dos casos 1 e 2 podem ser observadas, de maneira sistemática, em diversos outros produtos, inclusive em aplicações diferentes no veículo, como motorização, carroceria e chassis.

\subsubsection{Entrevistas sobre o APQP: importância, vantagens e dificuldades para lidar com os problemas levantados nos casos}

Com o objetivo de identificar fatores considerados importantes, vantagens e dificuldades do APQP, foi realizada uma pesquisa direcionada a profissionais da 
mesma montadora do estudo de caso 1 e 2 . Este estudo foi realizado com uma finalidade específica de entender 0 entrosamento dos profissionais com a metodologia e para buscar entender se questões que apareceram como importantes ou dificuldades que ocorreram nos casos estudados são freqüentes. Buscou-se também identificar se, na visão destes profissionais, o APQP deve ser usado para tratar estes problemas.

Entre os aspectos citados como importantes para que o APQP possa ser desenvolvido e aplicado adequadamente, estão:

a. Veracidade das informações;

b. O APQP precisa ser corretamente lido, entendido, ter informações consistentes, ter análise critica das informações;

c. Frequência adequada de atualização;

d. Deve haver um adequado fluxo de informações circulando entre os responsáveis dentro do fornecedor e da montadora;

e. O fornecedor precisa ter entendimento dos processos da montadora para entender a importância do conteúdo e saber como encaminhar as informações;

f. A montadora deve orientar adequadamente o fornecedor;

g. O processo da montadora precisa ser respeitado, como prazos, veracidade e fluxo de informações;

h. Deve haver uma pessoa na montadora que centralize e direcione as informações aos profissionais corretos;

i. A informação de projeto da montadora deve ocorrer no prazo adequado, como por exemplo: desenho e pedido de compra;

Podemos observar que, entre os entrevistados, as observações foram direcionadas para consistência de dados, fluxo de informações e correta utilização das 
informações. Os usuários entendem que a metodologia é importante e consistente e a questão a ser desenvolvida é como ela deve ser trabalhada.

Podemos observar, ainda, que o último item listado está diretamente relacionado aos problemas encontrados nos projetos estudados neste trabalho: desenho e pedido de compra no prazo adequado foi apontado como um fator importante, pelos próprios usuários, para que o APQP possa ser aplicado corretamente. 


\section{CONCLUSÕES}

A partir dos estudos de caso apresentados nos capítulos $4.1 .1 ; 4.1 .2$ e 4.1.3 e das entrevistas com os especialistas em APQP 4.1.4., serão apresentadas aqui as conclusões e recomendações.

Realizando uma análise global dos casos estudados, é possível perceber que houve problemas no primeiro desenvolvimento e estão ocorrendo problemas similares no desenvolvimento do segundo projeto analisado, bem como nos projetos analisados no capítulo 4.1.3. Ver análises realizadas no quadros 10, 11 e 12.

É possível observar que a maior parte destes problemas é devida a atrasos no cumprimento de prazos, ou a conseqüências do atraso, como, por exemplo, o fato de não se testar o protótipo que irá simular o produto a ser montado no veículo, devido à demora na definição de conceito.

Paralelamente, a contribuição mais significativa observada foi a recuperação de prazos. O fornecedor consegue trabalhar de maneira pró-ativa, antecipando seu trabalho, sem muitas vezes ter os inputs "formais" do projeto, como, por exemplo, acordos comerciais finalizados ou informações de design que deveriam ser fornecidas pela montadora antes de o fornecedor iniciar seu trabalho.

O trabalho simultâneo reflete uma parceria entre fornecedor e montadora que vai além das margens estabelecidas em contratos. O APQP, como um documento que auxilia a definição de atividades e prazos, não é suficiente para estabelecer esta parceria, mas certamente tem alto grau de contribuição, pois fornece uma visão comum das necessidades e atividades do projeto, possibilitando que seja criado este alinhamento entre montadora e fornecedor ao longo do processo. Este trabalho do fornecedor permite que parte dos atrasos seja compensada, "ocultando" parte dos problemas ocorridos ao longo do processo.

A importância do APQP, portanto, consiste em permitir a consulta, análise e relatório periódico das atividades e prazos a serem cumpridos por cada um dos responsáveis no processo. Através desta metodologia, é possível compartilhar esta visão e cada 
parte consegue visualizar, com certa antecedência, como o andamento das atividades de outros afetam seu próprio prazo. Além disso, estimula o dliálogo e planejamento conjunto de novos prazos, mesmo quando estes novos prazos estão fora do "cronograma oficial" da montadora.

De acordo com o cronograma da própria montadora, as atividades de definição de design e conclusão de acordos comerciais de produto e ferramental devem ser finalizadas antes que o fornecedor comece efetivamente a trabalhar e ter despesas com o projeto, como gastos com matéria prima, componentes, ferramentais ou dispositivos. Porém, com o APQP, o fornecedor possui a visão do prazo em que cada uma destas atividades deve ser concluída. Assim, muitas vezes, o fornecedor percebe que os atrasos da montadora se tornam críticos e que esperar o cliente concluir suas atividades tornará inviável, para o fornecedor, cumprir os prazos subsequentes. O fornecedor, na medida do possível, antecipa atividades de sua responsabilidade, sem os inputs formais. Não é uma engenharia simultânea planejada, mas sim uma iniciativa do fornecedor, sem o aval oficial do cliente, que informalmente é elogiada como atitude de parceria e compreensão das dificuldades internas.

O APQP não é uma metodologia única que pode fornecer a visão de prazos e atividades de projeto. Sendo ela a disponível para a equipe, ela é bem utilizada sob esta perspectiva.

É possível perceber, também, que a preocupação do fornecedor com o atendimento ao prazo é mais intensa que a dos profissionais da montadora. Existem algumas possibilidades que poderiam justificar este fenômeno:

a) A montadora possui dificuldades relativas à contratação de engenheiros para fases de pico de projetos e entende que o fornecedor, mais flexível sob este aspecto, deve absorver parte desta dificuldade, podendo "embutir no custo", de alguma maneira, esta ação, que é um evento comum neste mercado;

b) Como a última atividade, ou seja, a atividade que conclui o processo, é realizada pelo fornecedor, sempre o fornecedor acaba ficando com 
responsabilidade sobre o resultado, o que o faz ter maior interesse em evitar essa má performance;

c) O fornecedor, por ser o elo mais fraco da cadeia, sempre sofre a possibilidade de ser responsabilizado de alguma maneira, independente de qual empresa tenha cometido a falta. Para evitar o conflito, acaba tomando medidas que vão além da sua responsabilidade, para preservar seu relacionamento com a montadora;

d) As ações pró-ativas do fornecedor podem ser encaradas como uma forma de parceria, o que pode se tornar um diferencial competitivo e, de alguma maneira, motivar recompensas;

e) Estas ações estão "embutidas" no custo do fornecedor por serem percebidas como necessárias e por serem ações realizadas rotineiramente neste setor. Se não fossem realizadas, poderiam ser entendidas como uma fraqueza do fornecedor, pesando negativamente na sua competitividade.

Porém, foi possível observar que nem todas as deficiências puderam ser suprimidas e alguns problemas acabaram sendo carregados ao longo do processo como, por exemplo, protótipos que não correspondem ao produto final e problemas de qualidade nas primeiras entregas. Nestes casos, apesar de o APQP não prevenir estas falhas, ele se torna um veículo de registros do projeto que circula entre todas as partes, permitindo, mais uma vez, um alinhamento e esclarecimento dos problemas.

Em entrevistas com alguns profissionais dos fornecedores, esta foi apontada como mais uma vantagem do APQP, pois, em momentos posteriores, estes registros de projeto podem ser resgatados e a tratativa pode ser tornar mais fácil e consistente de ser trabalhada entre as empresas.

Ficou evidente que a maior parte dos aspectos apontados nos documentos está relacionada a prazo. Quando profissionais de fornecedores e montadora foram questionados sobre o foco em prazos e não em qualidade, a resposta foi clara: "a qualidade vem como consequência da realização adequada das atividades previstas no APQP". Assim sendo, se as atividades são realizadas adequadamente, a 
qualidade está sendo trabalhada. Da mesma forma, se as atividades estão sendo comprometidas, consequentemente a qualidade será afetada.

As evidências do caso 1 mostram que esta lógica realmente funcionou, pois as primeiras entregas tiveram problemas de qualidade, que ocorreram por falta de validação de processo antes da entrega ser realizada.

Durante a fase conclusiva deste trabalho, foi possível questionar alguns fornecedores que trabalham com outras montadoras, se atrasos similares ocorrem com as outras clientes, e a resposta foi positiva em todos casos. Houve um gerente de projeto de um fornecedor que declarou: "Parece que elas combinaram: neste momento, tenho três projetos, de diferentes montadoras, nas mesmas condições! Por isso não estou conseguindo mais absorver prazos e estou sofrendo por isso."

Isso sugere que as montadoras possuam uma visão que as leva para esta "estratégia de trabalho", tornando este cenário de atrasos possivelmente previsto e mais ou menos comum. Desta forma, o APQP, como um veículo de alinhamento e de registros, acaba sendo também um instrumento de defesa para o fornecedor durante o projeto e até mesmo em situações posteriores.

Pode-se sugerir, a partir deste trabalho que, sob alguns aspectos, o APQP funciona com uma dinâmica diferente da proposta originalmente. Hoje, ele pode ser utilizado como um instrumento que auxilia a orientação de prazos e alinhamento entre montadora e fornecedor e, algumas vezes, até mesmo como um instrumento de defesa para problemas futuros do projeto.

Respondendo à questão de pesquisa, "Quais as condições para que o APQP possa ser considerado uma metodologia efetiva para gerenciamento do processo de desenvolvimento de novos produtos?", é possível sugerir algumas condições para que ele funcione conforme a sua proposta original, que é a gestão do processo com a finalidade de realizar o planejamento avançado da qualidade do produto. Porém, não é possível dizer que o APQP, na prática, não funciona bem, mas sim que ocorrem algumas distorções do uso real, se comparado com a proposta original. Algumas condições que podem ser consideradas importantes para a gestão do processo a partir do APQP são: 
1. Os prazos estabelecidos pela montadora precisam ser realistas para atender aos processos da própria montadora e do fornecedor;

2. Os prazos internos de definições de atividades de engenharia e de definições de acordos comerciais precisam ser respeitados;

3. Atendendo aos itens 1 e 2 , será possível que os prazos para validações nos processos do fornecedor sejam respeitados, não comprometendo as últimas fases do APQP, de validação de produto e processo dentro do fornecedor;

4. A qualidade das informações, no que diz respeito à veracidade e clareza de dados, é fundamental para que os processos desenvolvidos correspondam às necessidades dos clientes;

5. O fluxo de informações, principalmente no que diz respeito à frequência de troca de dados, é importante para que informações já disponíveis sejam aproveitadas o mais rápido possível;

6. O conhecimento dos processos de desenvolvimento da montadora, bem como as dificuldades inerentes a ele, é importante para que cliente e fornecedor estejam cientes dos obstáculos a serem superados e como as atitudes de cada um podem contribuir para tanto.

As recomendações sugeridas, portanto, estão diretamente relacionadas ao cumprimento das disciplinas propostas na própria metodologia do APQP. As evidências deste trabalho sugerem que o processo de desenvolvimento proposto no APQP, se bem acompanhado, é consistente, por ser completo, abrangendo questões de prazos, qualidade e, consequentemente, custos. Com exceção de um único fator apontado nos casos, relativo à interferência de definições de prazo do governo, todos os demais fatores observados são abordados na própria metodologia, mostrando que ela é suficiente para a gestão do processo no que diz respeito aos aspectos levantados neste trabalho.

Porém, como qualquer metodologia, esta pode ser comprometida se conduzida de maneira inconsistente com a proposta. 


\section{REFERÊNCIAS BIBLIOGRÁFICAS}

ASSOCIAÇÃO NACIONAL DOS FABRICANTES DE VEÍCULOS AUTOMOTORES (ANFAVEA). Anuário Estatístico da Indústria Automobilística Brasileira. São Paulo, 2009. Disponível em: http://www.anfavea.com.br/anuario.html. Acesso em 21/08/2009.

BECKER, M. e ZIRPOLI, F. Organizing New Product Development. Knowledge hollowing-out and knowledge integration- the FIAT Auto case. International Journal of Operations and Production Management. vol. 23, N. 9, 2003.

BENITO, J. G. Barriers to the involvement of suppliers in design and product development: evidence in the Spanish auto components industry. International Journal Automotive Technology and Management. vol. 1. Nos. 2/3, 2001.

BERTOLINI, V. Os Fatores Críticos de Sucesso da Indústria de Autopeças no Brasil. Um Estudo Exploratório dos Níveis Hierárquicos da Cadeia dos Fornecedores da Indústria Automotiva, 2004. 129f. Dissertação (Mestrado em Engenharia de Produção) - Programa de Pós-Graduação em Engenharia de Produção, UFSC, Florianópolis.

BUTCHER, J.; JEFREY P. A view from the coal face: UK research student perceptions of successful and unsuccessful collaborative projects. Research Policy. vol. 36, p. 1239-1250, 2007.

CARVALHO, M. M. de; RABECHINI JR, R. Construindo Competências para Gerenciar Projetos: teoria e casos. São Paulo: Atlas, 2005.

CHIESA, V.; MANZINI, R. Organizing for technological collaborations: a managerial perspective. R\&D Management. vol. 28, 3, 1998.

CHRYSLER; FORD; GM. Advanced Product Quality Planning (APQP) and Control Plan, Reference Manual, 2nd edition, 2008. 
CHRYSLER; FORD; GM. Production Part Approval Process (PPAP). 4th edition, 2006.

CLARK, K. B.; FUJIMOTO, T. Product development performance: strategy, organization and management in the world auto industry. Boston: Harvard Business School Press, 1991.

; L Lead Time in Automobile Product Development Explaning the Japanese Advantage. Journal of Engineering and Technology Management. vol.6, p.25-58 1989.

COOKE-DAVIES, T. The "real" success factors on projects. International Journal of Project Management. vol. 20, p.185-190, 2002.

COOPER, R. G. Perspective: The Stage-Gates® Idea-to-Launch Process-Update, What's New, and NexGen Systems. The Journal of Product Innovation Management. vol.25, p 213-232, 2008.

CORMICAN, K. ; SULIVAN, D. Auditing best practice for effective product innovation management. Technovation,. vol. 24, p. 819-829, 2004.

CUSUMANO, M. A.; TKEISHI A. Supplier Relations and management: a survey of Japanese-transplant, and US auto parts. Strategic Management Journal. vol 12; 563-588, 1991.

DAVILA, T.; EPSTEIN, M. J.; SHELTON, R. As regras da inovação. São Paulo.. Bookman, 2008.

DE WIT, A. Measurement of project success. International Journal of Project Management, vol. 6, 1988.

DIAS, A. V. C. Produto mundial, engenharia brasileira: integração de subsidiárias no desenvolvimento de produtos globais no setor automotivo. São Paulo, 2003 303p. Tese (Doutorado) na Escola Politécnica da Universidade de São Paulo. Departamento de Engenharia da Produção. 
DONADA, C. Co-development partnerships: consequences for car suppliers. International Journal Automotive Technology and Management. vol. 1. Nos. 2/3, 2001.

DYER, J. H. Specialized Supplier Networks as a Source of Competitive Advantage: Evidence From the Auto Industry. Strategic Management Journal. vol. 15, p.271291, 1996.

EISENHARDT, K. Building theories from case study research. Academy of Management Review, vol. 14, No 4, p. 532, 1989.

FORTUNE., J.; WHITE, D. Framing of project critical success factors by a systems model. International Journal of Project Management, vol. 24, p. 53-65, 2006.

FUJIMOTO, T. The Japanese automobile parts supplier system: the triplet of effective inter-firm routines. International Journal Automotive and Management, vol. 1, No1, p.1-34, 2001.

GIARD, V.; MIDLER, C. Pilotages de project et enterprises: diversités et convergences. Paris: Economica, 1993.

GIL, A. C. . Como elaborar projetos de Pesquisa. São Paulo: Atlas, 2007.

GHAURI, P. GRONHAUG, K. KRISTIANLUND, J. Research methods in business studies: a Pratical Guide. New Jersey: Prentice-Hall, 1995.

JOHNSEN, T. FORD, D. At the receiving end of supply network intervention: The view from an automotive first tier supplier. Journal of Purchasing \& Supply Management, vol. 11, p. 183-192, 2005.

JOHNSTON, R., CLARK, G., Administração de operações de serviços. São Paulo: Atlas.. 2002. 
KAMATH, R.; LIKER, J. A Second Look at the Japanese Product Development. Harvard Business Review, p. 157-170, Nov/Dec, 1994.

KERZNER, H. In search of excellence in Project management. Journal of Systems Management. vol. 38, No 2, p. 30, 1987.

KERZNER, H. Gestão de Projetos: as melhores práticas. Porto Alegre: Bookman, 2006.

LAMMING, R.C. Squaring lean supply with supply chain management. International Journal of Operations and Production Management. vol. 16, No 2 ,183-196, 1996.

MARX, R. A indústria automobilística brasileira. In: Castro, N. A. A máquina e o equilibrista: inovações na Indústria automobilística brasileira. 1 ed. São Paulo: Paz e Terra, p 181-198, 1995.

MINTZBERG, H. . Criando organizações Eficazes. São Paulo: Atlas, 2003.

MARINHO, B. L. Gestão da cadeia de fornecedores e acordos de parcerias. In: NETO, J. (org). Manufatura Classe Mundial: conceitos, estratégias e aplicações. São Paulo: Atlas S.A., 2001.

MOREIRA, A. C. O problema da co-especialização no desenvolvimento colaborativo de novos produtos. Revista Produção. vol. 15, n. 1, p. 023-033, 2005

NAKANO, D. N. ; FLEURY, A. C. C. . Métodos de Pesquisa em Engenharia de Produção. In: Encontro Nacional de Engenharia de Produção, 1996, Piracicaba. XVI Enegep. Piracicaba : UNIMEP / ABEPRO, 1996.

PADOVANI, C. B. O papel da governança na cadeia de suprimento automotiva nos fornecedores de primeiro e segundo nível. São Paulo, 2007. 85p. Dissertação de mestrado. Escola Politécnica da Universidade de São Paulo. Departamento de Engenharia da Produção. 
PINTO, J.K.; D.P.SLEVIN. Critical Factors in Successful Project Implementation in: CLELAND, D. I.; KING, W, R. Project Management Handbook. New York : Van Nostrand Reinhold, 1983.

PINTO, J. K.; COVIN, J. G. Critical factors in project implementation: a comparison of construction and R\&D projects. Technovation.vol.. 9, p. 49-62, 1989.

Planejamento Avançado da Qualidade do Produto - APQP Manual de Referência, AIAG, segunda edição, 2008.

Production Part Approval Process. PPAP, Fourth Edition, AIAG, 2006.

QUESADA, G.; SYAMIL, A. DOLL, W. J. OEM New Product Development Practices: The Case of the Automotive Industry. The journal of supply chain management. $P$. 30-40. Summer 2006.

RO, Y. K.; LIKER, J. K.; FIXSON, S. K. Evolving Models of Supplier Involvement in Design: The Deterioration of the Japanese Model in U.S. Auto. IEEE Transactions on Engineering Management. Vol. 55, No. 2, May , 2008 p. 359 - 377.

ROZENFELD, H; FORCELLINI, F.A.; TOLEDO, J.C.; AMARAL, D.C.; ALLIPRANDINI, D.H.; SACLICE, R.K.;TOLEDO, J.C.; SILVA, S.L.; Gestão do Desenvolvimento de produtos. Uma referência para a melhoria de processo. São Paulo: Saraiva, 2006.

SALERNO, M.S., MARX, R., ZILBOVICIUS, M. and Dias, A.V.C. The importance of locally commanded design for the consolidation of local supply chain: the concept of design headquarters', Int. J. Manufacturing Technology and Management. vol. 16, No. 4, pp.361-376, 2009.

MARX, R., ZILBOVICIUS, M..A nova configuração da cadeia de fornecimento da industria automobilística na Brasil. Revista de administração da USP, vol.38, n3, p 192-204, 2003.

NEGRI, J. A. D. . Inovações padrões tecnológicos e desempenho das firmas industriais brasileiras. Ipea. 2005 
TANG, D. QIAN, X. Product lifecycle management for automotive development focusing on supplier integration. Computers in Industry. Vol. 59, p. 288-295, 2008.

THIOLLENT, Michel. A captação de informação nos dispositivos de pesquisa social: problemas de distorção e relevância. Cadernos CERU, n16, p81-105, 1981.

TORR, S., OGUNLANA. Critical COMs of success in large-scale construction projects: Evidence from Thailand construction industry. International Journal of Project Management. vol. 26, 2007.

TUMAN, G.J. Development and implementation of effective Project management information and control systems. In: D.I. Cleland and W. R. King (Eds.). Project Management Handbook. Van Nostrand Reinhold, New York, 1983, pp. 495-532.

VERGANTI, R. Planned flexibility: linking antecipation and reaction in product development projects. Journal of Product Innovation Management, vol. 16, No 4, , p. 363-376, 1999.

WESTERVELD, E. Project Excellence Model®: linking success criteria and success factors. International Journal of Project Management, vol. 21, No 6, 2003.

WOMACK, James; JONES, Daniel; ROOS, Daniel. A máquina que mudou o mundo. Rio de Janeiro: Campus, 1997.

YIN, R. Case Study Research. Bervely Hills, CA: Sage Publications, 1994.

ZANCUL, E. S.; MARX, R; METZKER, A. Organização do Trabalho no processo de desenvolvimento de produtos: a aplicação da engenharia simultânea em duas montadoras de veículos. Gestão e Produção. vol.13, p. 15-29, , 2006. 


\section{APÊNDICE A - Questionário para pesquisa de campo}

1) Como é realizada a comunicação para início do projeto, da montadora para a empresa fornecedora? Quando e como o fornecedor é informado? Quando o fornecedor começa, efetivamente, a trabalhar no projeto?

2) Quais são os documentos de registro de acompanhamento do projeto? Existe registro de APQP? Atas? Cronograma geral do projeto e de atividades intermediárias como construção de ferramentas e dispositivos? E-mails?

3) Nos projetos deste estudo, estão disponíveis os documentos de registro de acompanhamento existentes? - Recolher e entender este material, que será utilizado como base de análise da pesquisa.

4) Existe um cronograma da montadora a ser seguido? Como é elaborado o cronograma do fornecedor? Como ele se insere no da montadora?

5) Documentos internos são os mesmos daqueles reportados ao cliente? Se não, qual a diferença? (apenas para fornecedores)

6) Existem reuniões periódicas? Quem coordena? Qual a frequência? Como são registradas? (apenas para fornecedores)

7) De qual departamento é a responsabilidade pela coordenação do APQP? Como é a estrutura de acompanhamento do APQP dentro do fornecedor? Como as informações são difundidas e tratadas internamente?

8) Quem deveria participar do acompanhamento do APQP? Quem, de fato, participou? Quem deveria acessar estas informações e quem, de fato, acessou (inclusive no cliente)? Se houve dificuldades, como foram tratadas?

9) Dentro dos projetos estudados, quais são os aspectos particulares que podem ser extraídos das planilhas e do material de APQP disponibilizado? Como está/ foi o andamento real do projeto em relação ao planejado sob as análises de tempo, qualidade e custo? 
10)Como é divulgada e tratada a informação vinda do fornecedor dentro da montadora? Com qual frequência? (apenas para a montadora)

11)Qual o nível de modificação deste produto? O produto está sofrendo apenas um incremento ou a modificação é mais radical? Se for mais radical, a plataforma anterior é aproveitada? Tem tecnologia de outras fontes? Quais?

12)Quais os resultados de qualidade obtidos deste projeto? Qual era a performance de qualidade esperada? Qual foi a performance de qualidade obtida? Quais foram os resultados de testes e validação do produto?

13) Quais os resultados de prazo obtidos neste projeto? O que era esperado? O que foi obtido?

14) Como é a estrutura de projeto? Existe um gerente de projeto? A equipe técnica é dedicada ao projeto? É do tipo matricial? 


\section{APÊNDICE B - Questionário para pesquisa de campo}

\section{Questionário complementar sobre APQP}

1 - Quais as vantagens do uso do APQP?

2- Quais as desvantagens do uso do APQP?

3 - O que se faz necessário para que o APQP seja uma metodologia adequadamente aplicada?

4 - Quais são as dificuldades enfrentadas na aplicação da metodologia? 